University of Louisville

ThinkIR: The University of Louisville's Institutional Repository

Electronic Theses and Dissertations

$5-2012$

\title{
Ethnocentric frames across race : the media's role in activating ethnocentrism and public support for conflict abroad.
}

Christopher William Ledford

University of Louisville

Follow this and additional works at: https://ir.library.louisville.edu/etd

\section{Recommended Citation}

Ledford, Christopher William, "Ethnocentric frames across race : the media's role in activating ethnocentrism and public support for conflict abroad." (2012). Electronic Theses and Dissertations. Paper 803.

https://doi.org/10.18297/etd/803

This Master's Thesis is brought to you for free and open access by ThinkIR: The University of Louisville's Institutional Repository. It has been accepted for inclusion in Electronic Theses and Dissertations by an authorized administrator of ThinkIR: The University of Louisville's Institutional Repository. This title appears here courtesy of the author, who has retained all other copyrights. For more information, please contact thinkir@louisville.edu. 


\title{
ETHNOCENTRIC FRAMES ACROSS RACE:
}

THE MEDIA'S ROLE IN ACTIVATING ETHNOCENTRISM AND PUBLIC SUPPORT FOR CONFLICT ABROAD

\author{
By: \\ Christopher William Ledford \\ B.S., University of Louisville, 2009

\begin{abstract}
A Thesis
Submitted to the Faculty of the

College of Arts and Sciences of the University of Louisville in Partial Fulfillment of the Requirements

for the Degree of
\end{abstract}

Master of Arts

Department of Political Science

University of Louisville

Louisville, Kentucky

May 2012 
ETHNOCENTRIC FRAMES ACROSS RACE:

THE MEDIA'S ROLE IN ACTIVATING ETHNOCENTRISM AND PUBLIC SUPPORT FOR CONFLICT ABROAD

By

Christopher William Ledford

B.S., University of Louisville, 2009

A Thesis Approved on

April 24, 2012

by the following Thesis Committee

Dr. Jason Gainous

Thesis Director

Dr. Laurie Rhodebeck 


\section{DEDICATION}

This thesis is dedicated to my parents-Michael and Robyn Baker and James Ledford My brother and best friend-Jim Ledford And my late grandparents—James Burkett and Carl and Geraldine Ledford

Each whose wisdom, love, encouragement, and support have made all of my past and future academic endeavors possible. 


\section{ACKNOWLEDGMENTS}

I would like to thank my department committee members, Dr. Jason Gainous and Dr. Laurie Rhodebeck, for their impartial encouragement and dedication to teaching and research excellence, which has inspired me throughout my career at the University of Louisville and will continue to inspire me in all that I do. I would also like to thank my external committee member, Dr. Margaret D'Silva, for her comments and wonderful support throughout my thesis writing experience. Additionally, thanks to my Department of Political Science comrades, Brad Coffey and Kevin Fahey, for their invaluable feedback, enthusiasm, and tolerance of my complaining. Lastly, I would like to thank my closest friends-Powers Gillespie, Briana Wise, and Maggie LaFave—and the families of Steve and Jerry Ledford for pushing me, picking me up, and making me feel at home from the instant I began my career at the University of Louisville. 


\title{
ABSTRACT \\ ETHNOCENTRIC FRAMES ACROSS RACE: THE MEDIA'S ROLE IN ACTIVATING ETHNOCENTRISM AND PUBLIC SUPPORT FOR CONFLICT ABROAD
}

\author{
Christopher W. Ledford
}

April 24, 2012

This study revisits Kinder's and Kam's (2007; 2009) studies that provided political scientists with a theoretical and operational definition of ethnocentrism-our tendency to partition the world into in-groups and out-groups. They assert that the activation of ethnocentrism hinges on elite framing and issue-attention. In addition, they have shown whites to be more ethnocentric than blacks, generally. This thesis begins with, and after conducting a framing experiment, accepts the hypothesis that the media frame news ethnocentrically and that frames have a greater effect on activating ethnocentrism, fear, and support for war across white Americans than black Americans. Furthermore, my empirical analysis of ethnocentrism's effects on support for war, across race and over time, demonstrates that ethnocentrism is significant in driving support for war (across white individuals) at its onset, but I suggest that ethnocentric considerations are supplanted over time by considerations of the costs, implications of war, and decreasing interest. 


\section{TABLE OF CONTENTS}

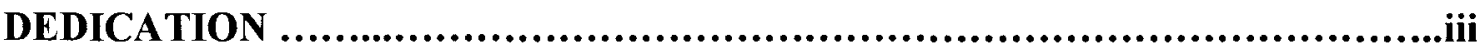

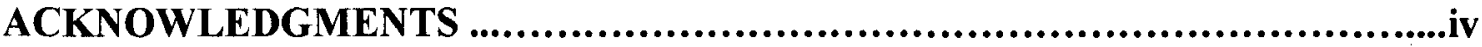

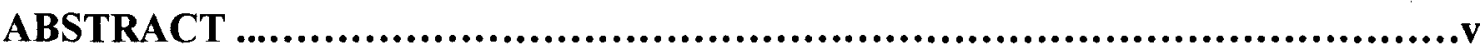

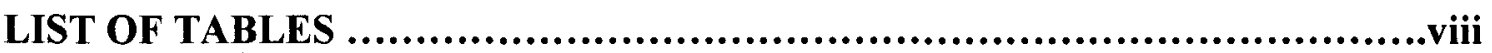

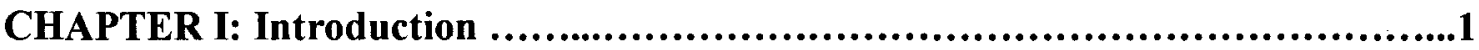

Us Against Them .................................................. 1

Research Questions - Ethnocentric Frames and Effects on Public Opinion .........3

Designing a Framing Experiment ........................................... 5

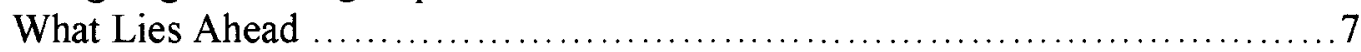

CHAPTER II: Theoretical Foundations ...............................................11

Four Previous Frameworks for Ethnocentrism .............................11

Ethnocentrism Reconceived: The Individual ............................... 19

Conflict Abroad ........................................................ 21

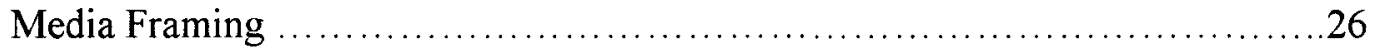

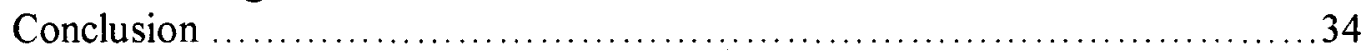

CHAPTER III: Ethnocentrism's Significance in Predicting Support for War Across

Time and Race .....................................................................36

Ethnocentrism in White and Black-2000-2002 _.............................37

Ethnocentrism and Support for War in Black and White-2002 _...............39

Ethnocentrism and Support for War in Black and White-2004 ...............43

Ethnocentrism and Support for War in Black and White-2008 ...............49

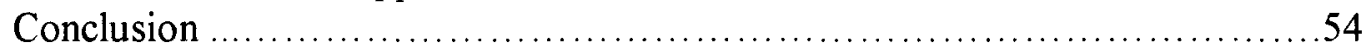

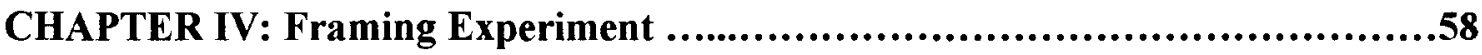

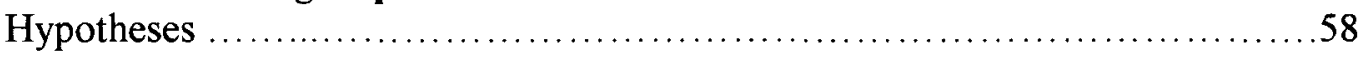

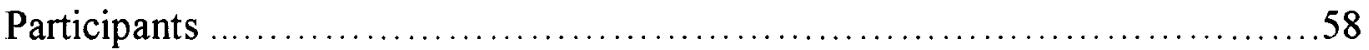

Ethnocentric Frame Construction .......................................61

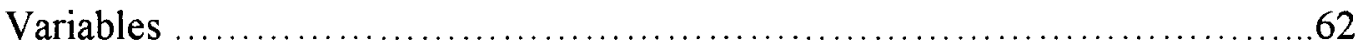

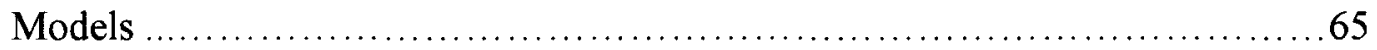

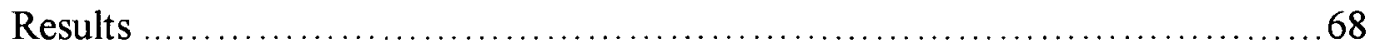




\section{TABLE OF CONTENTS (cont.)}

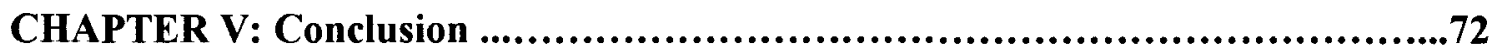

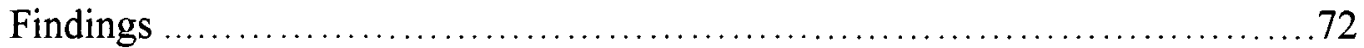

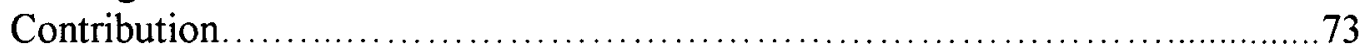

Drawbacks ........................................................ 74

Suggestions for Further Research ..................................... 75

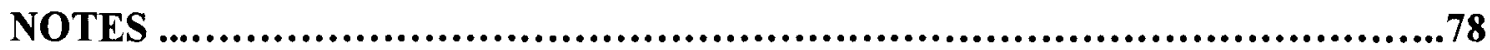

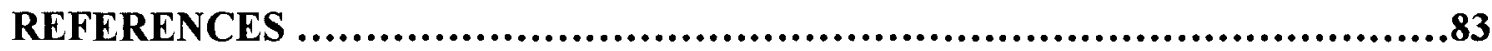

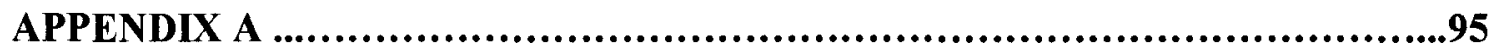

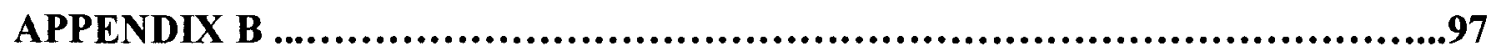

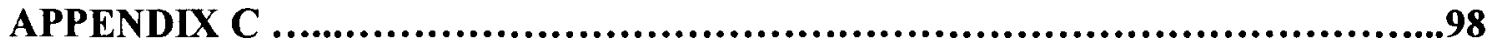

CURRICULUM VITAE......................................................107 


\section{LIST OF TABLES}

\section{CHAPTER III}

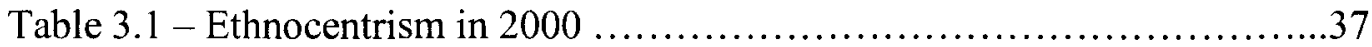

Table 3.2 - Ethnocentrism and support across race for the war on terrorism:

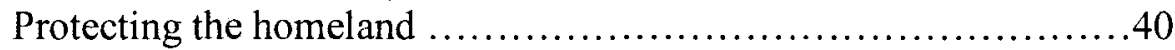

Table 3.3 - Ethnocentrism and support across race for the war on terrorism: Going to war ................................................41

Table 3.4 - Ethnocentrism and support across race for the war on terrorism: Backing the president .43

Table 3.5 - Ethnocentrism in 2004

Table 3.6 - Ethnocentrism and support across race for the war on terrorism in 2004: Protecting the homeland $\ldots \ldots \ldots \ldots \ldots \ldots \ldots \ldots \ldots \ldots \ldots \ldots \ldots \ldots$

Table 3.7 - Ethnocentrism and support across race for the war on terrorism in 2004: Going to war .......................................47

Table 3.8 - Ethnocentrism and support across race for the war on terrorism in 2004: Backing the president ...............................49

Table 3.9 - Ethnocentrism in 2008 .......................................... 50

Table 3.10 - Ethnocentrism and support across race for the war on terrorism in 2008: Protecting the homeland .................................52

Table 3.11 - Ethnocentrism and support across race for the war on terrorism in 2008: Going to war

Table 3.12 - Ethnocentrism and support across race for the war on terrorism in 2008: Backing the president

\section{CHAPTER IV}

Table 4.1 - Descriptive Statistics: 2008 ANES and Framing Experiment ........61

Table 4.2 - Ethnocentric Frames across Race: The Activation of Ethnocentrism and Fear ............................................... 70

Table 4.3 - Ethnocentric Frames across Race: Ethnocentrism, Fear, and Support for War ..................................................... 


\section{LIST OF FIGURES}

\section{CHAPTER III}

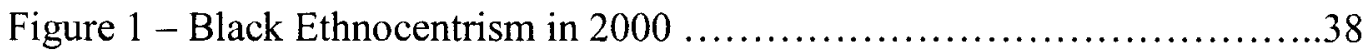

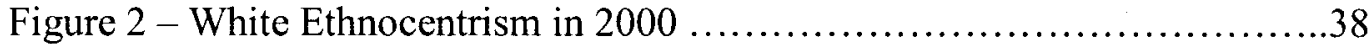

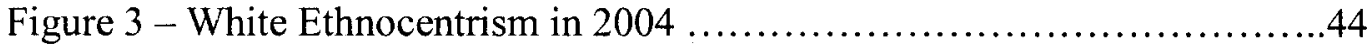

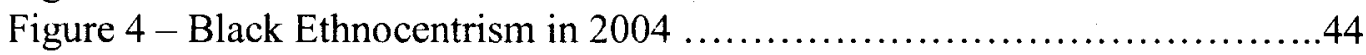

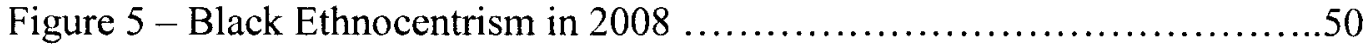

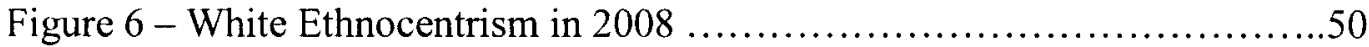




\section{CHAPTER I \\ INTRODUCTION}

\section{Us Against Them}

Ethnocentrism is a pervasive and deep-rooted readiness to partition the human world into in-groups (us) and out-groups (them) (Kinder and Kam 2009: 1-61)—more specifically, to us versus them (2009: 8). Ethnocentric individuals assume in-group members to be virtuous, friendly, trustworthy, and safe, and common symbols and practices within the in-group are sources of attachment and pride (Kinder and Kam 2009: 8). There is loyalty to the in-group, sacrifice will be made for it, and there is brotherhood within (Sumner [1906] 2002: 12-13). In contrast, out-group members are assumed to be unfriendly, untrustworthy, dangerous, and their practices are condescended, despised, and sometimes a source of hatred (Kinder and Kam 2009: 8). In-group members may generally fear outsiders, whereby support for conflict and violence draw in part on ethnocentric motives (Levinson 1949: 20). Ethnocentrism encompasses cognition (belief) and affect (feeling), involving emotions (both positive and negative) which may apply to one or numerous out-groups - to "aliens generally" (Adorno et al. 1950: 102).

Prior to Kinder's and Kam's $(2007 ; 2009)$ studies of ethnocentrism, four previous studies provided valuable insights into the social ramifications of ethnocentrism among groups. Kinder and Kam critique their predecessors for failing to explain ethnocentric differences across individuals. Furthermore, as the four previous studies were from apolitical disciplines, little had been said about ethnocentrism's role in shaping American 
public opinion, much less empirically tested. Accordingly, Kinder and Kam focused their work on the ethnocentric individual, and in due course, built a comprehensive political framework for ethnocentrism. Their reconceptualization provides new insights into the activation, origins, and implications of ethnocentrism as a politically consequential predisposition, influencing attitudes on numerous policy issues. Their sharpened individualistic focus and rigorous methods substantiate the claim that American public opinion cannot be fully understood without bringing ethnocentrism into account.

After providing their reconceptualization of ethnocentrism, Kinder and Kam insist that the impacts of ethnocentrism in shaping political decision-making hinge on the “dynamics of agenda setting" (Kinder and Kam 2009: 39). Drawing upon Downs (1957), Simon (1983), Kahneman and Tversky (1979), and Tversky and Kahneman (1974; 1981), and the theory of bounded rationality, Kinder and Kam assert that ethnocentrism is dependent on human attention and how issues are framed (2009: 38). They demonstrate that issues must command attention in order to activate ethnocentrism, and in the political arena, media decidedly control issue saliency, issue attention, and issue framing (2009: 39). Furthermore, activation is more likely when issues are portrayed as group conflicts, or in ways that encourage the public to perceive issues through ethnocentric lenses (2009: 39). They examine the effects of ethnocentrism on several salient issues: enemies abroad, foreign aid, immigration, gay marriage, welfare, and women's rights. These issues naturally put groups at odds and ethnocentrism becomes active as these policy issues gain attention from presidential announcements, campaigning, ballot proposals, terrorist attacks, and elections (2009: 97-103, 121-122, 146-149, 166-170). Kinder's and Kam's $(2007 ; 2009)$ studies provide political scientists with a new approach to understanding 
and operationalizing ethnocentrism, an understanding of the origins and implications of ethnocentrism, and evidence for ethnocentrism's significance in shaping public opinion across several high-priority issues facing the American public. However, their business is unfinished. These were significant contributions to the literature on ethnocentrism, but more importantly, they raised several pressing questions that beckon further research.

\section{Research Questions - Ethnocentric Frames and Effects on Public Opinion}

Do the media employ ethnocentric frames to manipulate public support for war?

Kahneman and Tversky (1984) asserted that media elites are able to manipulate citizens by strategically employing frames. If issue attention is so essential in the activation of ethnocentrism, then understanding how the media frame salient and highattention issues is equally as important. In this analysis, I confine my focus to ethnocentrism's effects on attitudes about war. Therefore, my inquiry specifically seeks to disclose if the media employ ethnocentric frames to manipulate public support for war. Given ethnocentrism's pervasive and pivotal role in shaping American public opinion surrounding salient and high-attention conflict issues (Kinder and Kam 2009), I suspect that ethnocentrism-activating frames are used correspondingly when the American media report on conflict abroad. In the next chapter, I provide historical and content analyses that evidence the media use of ethnocentric frames in stories of conflict. However, are those frames effective in activating ethnocentrism and manipulating public support for conflict? 
Do ethnocentric frames activate ethnocentrism and fear, thereby generating public support for war?

Kinder and Kam (2009: 103) showed us that ethnocentrism has sizable and significant effects in encouraging American support for war and confrontation. It dampens consideration for outsiders and undercuts American support for foreign aid (2009: 122). Ethnocentrism is significant in predicting discouragement of immigration, immigrants' rights, and gays' rights $(2009: 149,171)$. Ethnocentrism is powerful in encouraging support for social insurance for in-group members, while discouraging outgroup sustenance from public assistance (2009: 198). In this analysis, I focus on the effects of ethnocentrism on support for war, which is an interesting case to examine, given all that war entails in potential life, economic, and international relations costs. Given ethnocentrism's significant role in influencing support for war, I hypothesize that ethnocentric frames are correspondingly likely to activate ethnocentrism and fear, thus generating support for initiating war.

Are some groups more likely than others to be influenced by ethnocentric frames?

Kam and Kinder (2007: 324) find across many national samples (1992, 1996, 2000 ANES and 1990, 2000 GSS) that whites are generally more ethnocentric than blacks, based on respondents' ratings of in-groups and out-groups in America. Also, Sellers et al. (1998) claimed that some black identities are based on commonalities among blacks and other members of oppressed minorities. In these cases, where African Americans' identities also encompass members of other minority groups, they will be more likely to support programs designed to improve the situations of those groups. Muslims are a minority group in the context of America and a higher proportion of blacks 
subscribe to Islam than their white counterparts (2008 American National Election Study). Therefore, blacks are expected to be less ethnocentric generally and with respect to Islam. My hypothesis, based on these empirical and theoretical conclusions, is that white recipients of frames are more likely than black recipients to have their ethnocentrism activated by frames. Furthermore, I hypothesize that white recipients of ethnocentrically framed news regarding conflict are more likely than black recipients to support initiating conflict. Answering each of these core questions-lying at the intersection of race, ethnocentrism, media framing, and public opinion-is where my project builds upon what my predecessors began.

\section{Designing a Framing Experiment}

Kinder's and Kam's highly acclaimed research provided political scientists with a new way to operationalize and approach ethnocentrism, demonstrating that it is an important concept for political analysis. Political behavior scholar Samuel L. Popkin reviewed Kinder's and Kam's research, remarking that it is "learned, historically grounded, and theoretically ambitious" (Kinder and Kam 2009: Back Cover). Again, as important as what Kinder's and Kam's research provided political scientists, is the research that it paved the way for. Given ethnocentrism's significant place in understanding American public opinion, we must now answer these questions: Do the media employ frames to activate American ethnocentrism? Do ethnocentric frames activate ethnocentrism and fear, thereby encouraging support for initiating conflict? Are some groups (whites) more likely than others (blacks) to have their ethnocentrism activated by frames? In short, I hypothesize that the answers to each of these questions is "yes." 
Conflict Abroad with Iran? Islam? Muslims? Arabs? Middle Easterners?

The purpose of this project is to test each of these questions empirically in a framing experiment, emphasizing public opinion regarding conflict abroad. In the post9/11 world, amid on-going American troops' presence in Iraq and Afghanistan, and with particular respect to intensifying tensions with Iran, Islamic people are an ideal out-group on which to test ethnocentric frames. As I illustrate in the next chapter, Americans' negative perceptions and fear of Islam are decades old, due to "radical shift" in the 1970s resulting from "the explosion of Islamic politics onto the scene" (Gerges 2003: 75-76). Since the 1970s, high attention issues in the Middle East involving wars, embargoes, revolutions, a hostage crisis, terrorist attacks, and the recent military involvements in Iraq and Afghanistan, have inevitably caused American politicians and citizens to develop attitudes and form opinions about Islam. As I demonstrate in the subsequent chapter, the rise of fundamentalist Islam abroad and the use of rhetoric and stereotypes at home, often result in those attitudes and opinions being negative--perhaps, ethnocentric. Those stereotypes often lump Arabs, Muslims, and Middle Easterners into a collective negative image of violence and danger.

With decades of high-attention conflicts and negative enemy image construction of Islamists to serve my experiment, currently elevated domestic and international attention on Iran's nuclear development makes framing a conflict with Iran the ideal case on which to test the effects of ethnocentric frames. As mentioned earlier, I focus on framing effects across race, and use random assignment to framed and unframed fictional accounts of Iran's possession of nuclear weapons to test the effects of ethnocentrism across white and black participants. 


\section{What Lies Ahead}

In Chapter 2, I provide a comprehensive review of Kinder's and Kam's (2007; 2009) theoretically ambitious research that provided political scientists with a new individualistic view and operationalization of ethnocentrism, as well as an understanding of ethnocentrism's pivotal role in shaping American public opinion. I detail previous theoretical frameworks of ethnocentrism, as they were critiqued as incomplete, narrowly focused on groups, and largely irrelevant in understanding ethnocentrism's role in politics (Kinder and Kam 2009). I review Kinder's and Kam's reconceptualization of ethnocentrism as a predisposition that varies across individuals, define ethnocentrism's origins, and detail how it is activated. For the purposes of this experiment, I focus my review of their empirical section on the analysis of enemies abroad and how ethnocentrism effects support for war. In addition, I provide a literature review on media framing, which provides for the general assumptions regarding ethnocentric frames used in the media and generated for my experiment. At this juncture, I specifically provide literature that details the historical American and American media "othering" of Islam, and subsequently provide recent news articles that demonstrate how these ethnocentric framing techniques are in use in contemporary articles on Iran. Overall, this chapter will provide theoretical understandings of ethnocentrism and media framing, explain how they are independently and collaboratively crucial to understanding American public opinion, and demonstrate how these theoretical frameworks form my hypotheses.

Chapter 3 empirically describes recent trends in ethnocentrism as a predictor of support for recent wars on terror, in Afghanistan, and in Iraq. Duplicating Kinder's and Kam's operationalizations, I recreate their 2002 study of ethnocentrism's effects on 
support for war. I also create similar models, using 2004 and 2008 ANES data, to examine the significance of ethnocentrism in predicting support for war over time. Based on Kinder's and Kam's (2007: 324) finding that whites are more ethnocentric than blacks, I expected to find that ethnocentrism across white respondents would be a more significant and a more stable predictor of support for war over time.

Through this part of my research, I demonstrate that ethnocentrism is a more significant and stable predictor of war support across white respondents, but discover how the significance of ethnocentrism decreases across all respondents as the wars endured. Similar results were found in Kinder's and Kam's analysis of Desert Storm (2009: 101). In the conclusion of this chapter, I find that, while attention and framing are crucial in activating ethnocentrism, perhaps Downs' (1972) issue-attention cycle is the best lens through which to examine the long-term significance of ethnocentrism in predicting support for an enduring war. Downs proposed that issues go through an attention cycle where the public suddenly becomes aware of and alarmed by the evils of a problem, which is usually accompanied by high levels of enthusiasm (1972: 39). In this case, I suggest when the public suddenly becomes interested or aware of war, their attitudes are accompanied by high levels of ethnocentrism. The public eventually begins to realize the costs of making progress, which leads to a gradual decline in the intensity of public interest (1972: 40). In this case, as the public loses interest, the effect of ethnocentrism also diminishes. In the last stage, the once important issue "moves into a prolonged limbo," where it may intermittently summon the public interest (1972: 40). I suggest that once wars move into this state of limbo, perhaps only the most ethnocentric see war as "us versus them." High attention and framing are no doubt instrumental in 
activating ethnocentrism and generating support for war, as demonstrated by Kinder and Kam. Following Down's cycle, I propose that at the onset of conflict, high public support is most likely to be accompanied by high levels of ethnocentric thinking, as a result of attention and framing. However, through my analysis of ethnocentrism across time and race, I propose that as the public realizes the costs of war, public interest and the significance of ethnocentrism diminishes. As casualties, economic costs, and domestic criticisms increase, these factors become decisive in American support (or lack thereof). As public interest wanes, support is viewed increasingly less through ethnocentric lenses. As conflict issues move into the final stage, perhaps the extreme cases still view the issue through an ethnocentric lens, but the significance of ethnocentrism as a predictor of support is largely supplanted by these more domestic considerations

Chapter 4 details the setup and execution of the framing experiment. I describe the sample of University of Louisville students, their recruitment for the study, and compare them demographically to the 2008 ANES sample. Based on the theoretical and general assumptions provided in Chapters 2 and 3, I describe how the frames and questionnaires were constructed for the experiment. I detail how the results from the experiment are operationalized following Kinder's and Kam's research and how modifications were made to their original model for my purposes. Finally, I present the results of the framing experiment and the results across my racial sub-groups. I found that the ethnocentric reinforcing frames were significant in activating ethnocentrism and fear across white participants. Reinforcing the finding that frames influence whites, I also found that ethnocentrism was not activated across black participants, regardless of which account they read. Using the predicted responses to perception of threat within 
subsamples of groups receiving the frame and groups not receiving the frame, predicted by ethnocentrism and a list of control variables, I then predicted support for war. I found that not only are frames successful in activating ethnocentrism and significant in predicting fear across whites, but that fear arising from ethnocentrism is significant in predicting support for going to war across whites.

Chapter 5 provides a discussion of the results from the framing experiment, the potential implications of ethnocentric frames in causing whites to support going to war, and suggestions for further research. I conclude that the findings in my research are monumental, given that frames affect white support for going to war, and considering that the most recent presidential electorate was three-quarters white. I provide suggestions to address the sampling biases and other issues that compromise the generalizability of my research and also suggest that further research take my hypotheses, experiment, and race analyses and apply them to other policy arenas. 


\section{CHAPTER II}

\section{THEORETICAL FOUNDATIONS}

\section{Four Previous Frameworks for Ethnocentrism}

\section{Ethnocentrism Arising from Intergroup Competition}

Any academic or professional publication that studies ethnocentrism begins with the work of William Graham Sumner (1906). Sumner first coined the term ethnocentrism as

"...the technical name for this view of things in which one's own group is the center of everything, and all others are scaled and rated with reference to it. Folkways correspond to it to cover both the inner and the outer relation. Each group nourishes its own pride and vanity, boasts itself superior, exalts its own divinities, and looks with contempt on outsiders. Each group thinks its own folkways are the only right ones, and if it observes that other groups have other folkways, these excite its scorn" (Sumner 1906: 13).

Graham writes that ethnocentrism strengthens the folkways, citing several examples, as it causes people to embellish everything in their own folkways that is unique and distinguishes them from others (Sumner 1906: 13). The Papuans of New Guinea, broken up into village units integrated by language, religion, and interests, were peaceful groups within and hostile to all outsiders (Sumner 1906: 13). The Mbayas of South America believed their deity commanded them to make war on others, to pilfer 
their wives and possessions, and to kill their men (Sumner 1906: 13). Groups label themselves ethnocentrically, while outsiders are undefined, seen as unvirtuous or inferior (Sumner 1906: 14). ${ }^{1}$ Over a century ago, Sumner claimed ethnocentrism to be a universal predisposition toward in-group solidarity and out-group hostility arising from intergroup competition (Kinder and Kam 2009: 9), and found evidence of ethnocentric in-group labeling, belief, and culture. Sumner's examples and his work endure as a cornerstone of contemporary realistic group conflict theory (2009: 9).

Realistic group conflict theory holds that animosity between groups derives from actual conflict, in which groups are contending for economic, social, and political resources (2009: 9). However, from this theoretical perspective, generalized prejudice is possible only in the presence of intergroup conflicts. Sumner's work was undoubtedly essential behavioral work in sociology, as he first defined ethnocentrism and defined the circumstances for which studies of ethnocentrism must account. However, Kinder and Kam sought to explain ethnocentric differences across individuals through the lens of American public opinion, a task to which group conflict theory offered little assistance (2009: 11). Likewise, group conflict theory has little to offer my objective-explaining ethnocentric framing effects across individuals. The particularity of realistic group conflict is its shortcoming, as the framework has little to say about generalized hostility or generalized prejudice (2009: 11).

\section{Ethnocentrism as an Outgrowth of the Authoritarian Personality}

Adorno, Frenkel-Brunswik, Levinson, and Sanford (1950) published a series of studies representing the first systemic social scientific treatment of ethnocentrism (Neuliep and McCroskey 1997: 386). Adorno et al. (1950) analyzed data from over 2000 
questionnaires and over 80 clinical interviews, as they studied the psychologies of fascism, anti-Semitism, and the "antidemocratic personality" (Neuliep and McCroskey 1997: 386). In their study, Adorno and his colleagues argued that nationalism is a species of ethnocentrism, ethnocentrism is an expression of authoritarianism, and that authoritarianism is a personality defect (Forbes 1985). Levinson (1950) added that ethnocentrism is "based on a pervasive and rigid ingroup - outgroup distinction" (Adorno et al. 1950: 150). Under Levinson's distinction, out-groups are subject to negative stereotypes and imagery, and hostile attitudes; in-groups are subject to positive stereotypes and imagery, and submissive attitudes; and a hierarchical authoritarian view of group interaction sees in-groups as rightly dominant over out-groups (Adorno et al. 1950: 150).

Adorno and his colleagues (1950) theorized that prejudices against minorities and ethnic groups were part of a more generalized personality profile and that prejudices should not be studied in isolation. ${ }^{2}$ Following this mode of thinking, they created an ethnocentrism scale, also known as the $E$ scale, consisting of three subscales pertaining to Jews, blacks, and other minority groups, as well as patriotism (Neuliep and McCroskey 1997: 387). Their purpose was to combine the scores from the three subscales and treat the combination as a singular measure of ethnocentrism (1997: 387). However, the $E$ scale was designed for white populations during the 1950s, making it outdated and, ironically, ethnocentric (1997: 387). Nevertheless, this conceptualization paved the way for subsequent studies that reformed the operationalization of ethnocentrism. ${ }^{3}$ In due course, we can trace the operationalization of ethnocentrism adopted by Kinder and Kam (discussed later), through previous studies, and back to Adorno and his team's work. 
According to Neuliep and McCroskey (1997), Adorno et al. (1950) have been harshly critiqued by numerous researchers for a range of reasons. Kinder and Kam note that among the shortcomings of their study was sample bias, due to a disproportionately social middle class, and measurement error, as all of the propositions in the ethnocentrism battery were written to run in the same direction (Kinder and Kam 2009: 15). In all cases, agreement indicated a propensity toward anti-Semitism, ethnocentrism, or authoritarianism, thereby conspicuously inflating the relationships between their scales (2009: 15).

Overall, Adorno and his colleagues were correct to postulate that people differ in their overall outlook toward others, that people are more or less ethnocentric, and that ethnocentrism may be an outgrowth of the authoritarian personality. Several subsequent studies have reaffirmed that prejudices against minority and ethnic groups constitute a general attitudinal profile. ${ }^{4}$ However, Adorno and his team focused on ethnocentrism as a personality trait, a simplification that ignored the intrinsic role that elites and media may play in the activation and mobilization of ethnocentrism (Neuliep and McCroskey 1997: 386; Kinder and Kam 2009: 18). This significance of this role is exactly what I demonstrate with my framing experiment.

\section{Ethnocentrism as an Expression of Social Identity}

Henri Tajfel and his colleagues (1971) focused on ethnocentrism as an expression of social identity, attempting to define the environmental conditions that give rise to ingroup favoritism. Their minimal group experiment questioned group conflict theorywhether conflicts of interest were necessary to produce ethnocentrism. They believed that it was possible for a group, along with its associated prejudices, to form with no prior 
contact, knowledge, or consequential behavior (Hammond and Axelrod 2006: 2; Kinder and Kam 2009: 19). In the experiment, teenage boys were randomly assigned to groups and asked to allocate rewards to participants in their group or the other group (Tajfel et. al 1971; Buchanan 2007; Kinder and Kam 2009: 19). Over 70 percent of participants allocated rewards in a way that favored their group, leading to the conclusion that if people are grouped, even without prior association, in-group biases will emerge (Tajfel et. al 1971; Locksley et. al 1980; Kinder and Kam 2009: 19). The same minimal group effect of Tajfel's research has been found in numbers of successive studies, and the tendency to distance "us" from "them" is remarkable, even when participants were told that group membership was determined randomly, and when doing so diminishes ingroup rewards. $^{5}$

From the minimal group experiment, Tajfel and his colleagues created social identity theory, which posits that individuals are always striving to maintain or enhance their self-esteem through social group memberships and the perception of belonging (Tajfel and Turner 1979: 40; Tajfel 1981: 255). Membership transforms into a sense of identity through social categorization, wherein the social world is viewed in manageable categories of "us" and "them," and people accentuate similarities between themselves and in-group members while emphasizing differences between themselves and any number of out-groups. Again, Kinder and Kam (2009: 22-23) note that Tajfel, Brewer (1999; 2007), and other social identity theorists display little interest in differences among individuals. They suggest that Tajfel's findings were more or less stating the obvious-that all of us strive for self-esteem and security, and are likely to seek in-group membership-and continue toward their reconceptualization of ethnocentrism in the individual (2009:30). 
Ethnocentrism as an Outcome of Natural Selection

Harvard entomologist Edward O. Wilson boldly asserted that natural selection is "the essential first hypothesis" for comprehending the human condition (1978: 1-2). According to Wilson, the social sciences are only capable of scratching the surface when describing human behavior until they adopt the lessons of evolution and natural selection (1978: 1-2). Wilson posited that certain human social traits are unique and universal in the human species (1978: 21) and found that the evidence amassed for a large hereditary component to human social behavior is conclusive (1978: 19).

Kinder and Kam (2009: 25) suggest that perhaps ethnocentrism is a part of human nature. Social life entails the sharing of resources and defense, and it seems that natural selection would favor motivational dispositions furthering group life (Kinder and Kam 2009: 25). Consequently, mutations furthering the capacity for in-group loyalty and outgroup hostility might have spread throughout the population (Wilson 1978; see Campbell $1965 ; 1975)$.

Darwin (1871: 489-90) proposed that human morality rested on evolutionary processes and emphasized the moral continuity between humans and animals. Rushton (2005: 491) reviews how Darwin provided examples of how animal morality led to reproductive success, showing that animals fight but are also altruistic. However, Darwin saw the paradox that altruism posed for the theory of evolution (Darwin 1871: 114; Rushton 2005: 492). It seemed inherent that altruism cannot evolve through "survival of the fittest," if it entails self-sacrifice (Darwin 1871: 114). Following this line of thought, Kinder and Kam note that the evolution of ethnocentrism seems unlikely, if ethnocentrism requires in-group loyalty to the degree of self-sacrifice (2009: 25). If the 
most altruistic members of a group sacrifice themselves, they will have fewer offspring to pass on the altruistic genes (Darwin 1871: 114; Kinder and Kam 2009: 25). Nevertheless, altruism most certainly exists in the world. Darwin suggested that altruism might be explained by natural selection acting on groups, as it does on individuals (1871: 115116). Since Darwin, biologists have continued to try to explain altruism through group selection models. Under group selection, altruism can evolve where many groups vary in their proportion of altruistic types (Kinder and Kam 2009: 26). Groups with more altruists must be more fit and produce more offspring, and the differential fitness of groups (favoring altruists) must be strong enough to counter the differential fitness of individuals within groups (favoring the selfish) (2009: 26). Because altruism is "maladaptive with respect to individual selection but adaptive with respect to group selection, it can evolve only if the process of group selection is sufficiently strong" (2009: 26). Evidence in support of group selection is now overwhelming and group selection has become a dominant view (Sober and Wilson 1998; Lloyd 2001; Okasha 2006).

Kinder and Kam (2009: 26) assert that if natural selection operates on groups as well as individuals, and this is especially true for humans, this does not mean that all humans are altruistic and generous. They posit that group selection theory provides a supplementary setting in which competition can occur and does not replace individual selection, but leaves space for altruistic motives to intermingle with the purely selfish (2009: 26). Finally, they affirm that altruism rooted in natural selection is not universal, but is for the benefit of the in-group and the detriment of the out-group (2009:26). If group selection provides the mechanism by which helping behavior directed at members 
of one's own group can evolve, "it equally provides a context in which hurting individuals in other groups can be selectively advantageous. Group selection favors within-group niceness and between-group nastiness"—or "ethnocentrism" (Sober and Wilson 1998: 9; Hammond and Axelrod 2006; Kinder and Kam 2009: 26).

Group selection proposes that ethnocentrism can be regarded as an adaptation-a part of "human nature"-riding on the general point that key features of human behavior evolved by natural selection and are today constrained throughout the entire species by a particular set of genes, making a case for ethnocentrism as a general disposition (2009: 26-27). Focused on the individual, Kinder and Kam question genetics' role in individual differences in ethnocentrism (2009: 27). They believe that individual Americans differ in the degree to which they display ethnocentrism, in part due to differences in "genetic blueprints" (2009: 27).

Furthermore, a great genetic component to conservatism was found in a large sample of identical and fraternal twins, where more than half of the observed variation in conservatism was attributed to genetic difference (Kinder and Kam 2009: 29). ${ }^{6}$ Other studies cited by Kinder and Kam (2009: 29), employing different designs, different samples, and different methods arrive at the same conclusion. ${ }^{7}$ Conservatism, it would seem, arises in an important way from genetic endowments, and similarly, variation in genetic programming might explain nearly half of observed variation in ethnocentrism (Kinder and Kam 2009: 29). While Wilson and other sociobiologists have demonstrated that ethnocentrism is part of human nature and that humans are more or less ethnocentric due to genetic inheritance, the question remains: "Do individual differences in ethnocentrism have a genetic source?" (2009: 29-30). 


\section{Ethnocentrism Reconceived: The Individual}

The four aforementioned frameworks, coming from psychology and natural science, do not address the inherent role that political elites and the political media play in the activation of ethnocentrism in individuals. Therefore, Kinder and Kam (2009: 3141) propose a political reconceptualization of ethnocentrism, beginning with discussions of the nature of ethnocentrism, the origins of ethnocentrism, and the consequences of ethnocentrism. According to their framework, the ethnocentric predisposition varies in degree across individuals. Out-group members range from strange to discomforting to dangerous (2009: 31). Any aggregation of individuals can constitute an in-group, as long as it is experienced as such and there is a psychological striving to belong (2009: 32). The nature of politics, constituted by groups and attachments, is an ideal breeding ground for the activation of ethnocentrism, which depends on elites' framing and the media. While their empirical section of issue studies discusses activation, as those issues become salient, they do not experiment with the roles and effects of framing.

\section{Origins of Ethnocentrism}

Focused on ethnocentrism in the individual, Kinder and Kam assert and empirically demonstrate that variations among ethnocentric individuals arise from three primary sources: parental influence, the authoritarian personality, and levels of education (2009: 32-35). Parental influence may be in the form of genetic transmission and/or social learning (2009: 33). As Martin (1986) found a similar disposition, conservatism, to have a substantial genetic component, Kinder and Kam propose that "part of the mystery of individual differences in ethnocentrism... lies in our genes" (2009: 33). Children may also inherit ethnocentrism by "imitating, internalizing, and reproducing what their parents 
say and do" (2009: 33). By nature, authoritarians prefer social cohesion and uniformity, authority to independence and diversity, and "should be drawn 'naturally' to ethnocentrism" (2009: 34). Finally, education provides individuals with the resources to evaluate circumstances with tolerance, while less educated Americans are more prone to be ethnocentric (2009: 35).

\section{Setting the Agenda}

Individuals are more or less ethnocentric, but activation is conditional. As discussed in the introduction, Kinder and Kam assert that the impacts of ethnocentrism in shaping political decision-making hinge on the "dynamics of agenda setting" (2009: 39). Issues must command attention in order to activate ethnocentrism, and the political media machine decidedly controls issue saliency, issue attention, and issue framing (2009: 39). What Americans consider important is decided for them. Such is the nature of politics, that when salient political issues are portrayed as group conflicts or in ways that encourage the public to perceive issues through ethnocentric lenses, activation is more likely (2009: 39).

\section{Empirical Tests and Role in Public Opinion}

Focused here, on what issues are important and how ethnocentrism influences public opinion, Kinder and Kam test the correlations between ethnocentrism and several variables important in understanding American public opinion. Ethnocentrism is found to have no significant correlations with partisanship, ideological identification, and known associates — conservatism, anti-egalitarianism, and social trust—demonstrating that "ethnocentrism represents a distinctive outlook on social life... that... has [an] independent impact on public opinion (2009: 58-61). 
Kinder and Kam empirically test ethnocentrism's influence in several highattention policy domains, the first of which is "enemies abroad" (discussed at length later). They demonstrate that ethnocentrism is a foundational element of public opinion, significant in predicting support for war and in predicting opposition to gay rights, welfare, and affirmative action. An important conclusion to be drawn from these findings is that if ethnocentrism influences opinion, and opinion influences policy, then ethnocentrism can have a sizable impact on policy outcomes. The very purpose of this experiment is to demonstrate that ethnocentric frames can activate ethnocentrism, shape opinion, and sway individuals towards policy support. In short, I suspect that ethnocentric frames can ultimately affect policy outcomes. In the war policy arena, this is no doubt significant, given the economic, life, and international consequences of conflict. With my focus on "enemies abroad," I now turn to a brief discussion of Kinder's and Kam's corresponding empirical chapter. As Kinder and Kam readily admit, their methods are "hardly foolproof-[as] drawing causal inferences from non-experimental data remains tricky business" (2009: 78). The forthcoming discussion describes the significant role ethnocentrism plays in attitudes about foreign conflict, as discovered by Kinder and Kam, while the forthcoming empirical section applies their model to an analysis of ethnocentrism's effects on attitudes about the wars in Iraq and Afghanistan across race and time.

\section{Conflict Abroad}

Attention

In the last decade alone, foreign conflict has entailed the losses of thousands of American lives, the expenditure of trillions of American dollars, and has had serious 
implications for American foreign relations. The international, financial, and humanitarian implications of war put conflicts at the front of the issue agenda. Combined with the rhetoric, enemy image construction, and framing of war, discussed at length in the next section, it is certain that "nothing attracts and holds the public's attention like warfare" (2009: 73). After all, ethnocentrism's definer regarded conflict to be the primary source of ethnocentrism (Sumner 1906).

Estimating the Effect of Ethnocentrism

Kinder's and Kam's model for estimating the effect of ethnocentrism relies heavily on their previously discussed framework. Focusing on the war, they include three plausible explanations of support for conflict (supplementary to ethnocentrism), which ultimately become control variables for partisanship, education, and perception of threat (2009: 79). Partisanship and education are powerful predictors of public opinion, and the inclusion of perception of threat draws on realistic group conflict theory and the prediction that "support for waging war on... terrorists should be proportionate to the severity of the threat...pose[d]" (2009: 79). They also control for gender, on the prediction that women are more reluctant than men to deploy troops. The $E$ scale is a measure of in-group favoritism over out-groups, represented by responses to a stereotype battery. The battery asks respondents to rate groups on intelligence, trustworthiness, and hard work, summing the differences in the rating for the in-group and the average outgroup rating. Nearly $60 \%$ of pooled respondents scored above the neutral score of zero, in the range of ethnocentrism (2009:57). ${ }^{8}$ 


\section{Ethnocentrism and Support for War}

With their model constructed, Kinder and Kam demonstrate the impressive significance of ethnocentrism in predicting American support for the war on terrorsupport for increased spending on several measures of homeland protection, support for measures of going to war, and approval of several measures of the president's job during war. Furthermore, positive coefficients were found on the in-group pride components and negative coefficients were reported on the out-group components, entailing support for war on terror does not stem from either in-group loyalty or out-group hostility alone, but both—in other words, ethnocentrism (2009: 85-86).

Supplementing their analyses of ethnocentrism's influence on support for the war on terror, Kinder and Kam also find ethnocentrism to be a statistically significant predictor of support for Cold War and Operation Desert Storm. Ethnocentrism is a statistically significant predictor of support for preventing the spread of communism, dealing tougher with the Soviet Union, and the disapproving of arms agreements, as well as responses of pride and anger, support for military force, and support for the president's general performance and management of the Gulf crisis (2009: 90-92).

\section{Activation}

The 9/11 attacks were the first on American soil in nearly sixty years, resulting in the deaths of 2,977 Americans (Glazier 2008). For the first time in the nation's history, the Plan for the Security Control of Air Traffic and Air Navigation Aids was enacted, grounding all non-essential air traffic in the United States in the hours after the attacks (911Review 2003). In the months that followed and on the anniversaries of 9/11, countless stories were written and aired about families' losses and the sacrifices of 
emergency personnel after the attacks. A new Department of Homeland Security (Department of Homeland Security 2011) was created, the National Security Agency was given broader powers, and the new USA Patriot Act was implemented, aimed at detecting and prosecuting terrorists (United States Department of Justice 2010). Less than one month after the attacks, Operation Enduring Freedom was launched in Afghanistan and President George W. Bush asserted, "Full warning has been given. For those nations that stand with the terrorists, there will be a heavy price" (Wintour et al. 2001). The attacks had widespread implications for American and international markets (Congressional Research Service 2002). During Bush's second term, doubt began to surround a lack of focus in Afghanistan, which was inherited by the Obama administration. On May 1, 2011, nearly a decade after the attacks, 9/11 was again the dominant issue in America's mind. President Obama gave a late night address to the nation, powerfully and patriotically declaring our nation had endured ten years of struggle, and had finally killed bin Laden. ${ }^{9}$ Finally, in July 2011, the continuing withdrawal of American troops in Afghanistan commenced (Welker 2011). From nearly every policy standpoint, opinion, attitude, and individual effect of the attacks and subsequent wars, there is no doubt that the 9/11 attack and its consequences have commanded and held the public's attention, more so than any other event in American history.

With this in mind, Kinder and Kam sought to test whether 9/11 activated ethnocentrism and made it a more significant causal mechanism for war support than in the period prior to the terrorist attacks- the 2000-2002 ANES panel suited this task perfectly (Kinder and Kam 2009: 97). They test ethnocentrism's significance in predicting spending support on border security, national defense, homeland security, the 
war on terrorism, as well as support for going to war and support for the president. The role of ethnocentrism in public opinion was significantly higher in the 2002 portion of the study. In 2002, ethnocentrism became more significant in predicting spending support for tightening border security, became highly significant in predicting support for national defense spending, and became significant in predicting support for Bush (2009:98). The results demonstrate, in dramatic fashion, that the events of $9 / 11$ activated ethnocentrism in American individuals. The conclusions are similar in their analysis of activation and ethnocentrism before and after Desert Storm. Repeatedly, ethnocentrism is demonstrated to boost American support for confrontation, especially going into war. More important, given the variety of conflicts tested and the way ethnocentrism is measured, these tests are paramount to understanding ethnocentrism as a "general aversion" in the form of both in-group pride and out-group hostility, not just an aversion to fundamentalists, Soviets, or Arabs (2009: 104).

With a theoretical and political understanding of ethnocentrism in hand, as well as an understanding of some of the sources of ethnocentric fluctuations across individuals, and evidence of ethnocentrism's effects on increasing support for war, I return to framing. Again, ethnocentrism is activated in political judgment when an issue commands adequate public attention, or when it becomes psychologically meaningfulas decided by media. Few issues garner the public's attention to the degree that war does. War is a high priority issue, typically portrayed as a "struggle between good and evil," which certainly challenges people's predispositions and causes defensive mental mechanisms to swing into action - a perfect breeding ground for ethnocentric judgments (2009: 73). Given the attention that surrounds conflict and ethnocentrism's pervasive role 
in America, that the media can frame conflict news ethnocentrically to that activate ethnocentrism. I provide literature on media framing and evidence that framing techniques are used by the media when reporting conflict, which serve in the construction of the frames and experiment I create to test this hypothesis.

\section{Media Framing}

\section{The Framing Process}

Norrander and Wilcox (2002: 4) claim that recent research seeks to account for "seemingly contradictory opinions among the American public," emphasizing how political information is conveyed. The studies analyze issue frames, aimed at altering perceptions of political issues (2002:4). The overall idea of framing effects is that frames are coherent packages of information that shape the public's understanding and reaction to political events and issues (Gross and D'Ambrosio 2004; Gamson and Modigliani 1987: 143). News frames are patterns of selection, interpretation, and presentation that give order and meaning to the intricacies of politics (Gitlin 1980). In other words, framing is "the process by which a communication source constructs and defines a social or political issue for its audience" (Nelson, Oxley, and Clawson 1997: 221; Entman 1993). The framing process entails how the story is written and produced, particularly the adjustment of headlines, word usages, use of rhetorical devices, narration, and so forth (Cappella and Jamieson 1997). Frames are strategically employed, with the intention of their ideas and languages "resonat[ing] with larger cultural issues" (Gamson and Modigliani 1987: 169). Politicians seek to "activate" those larger issues by "fram[ing] public events to their advantage (Norrander and Wilcox 2002: 5). Framing effects may directly affect opinion formation, or they may affect the considerations on which an 
opinion is based (Brewer and Gross 2005; Druckman 2001b; Sniderman and Theriault 2004). Recent research has established that such factors as the recipient's emotional response to a frame (Brewer 2001), the recipient's perceptions of the strength of a frame (Brewer 2001; Chong and Druckman 2007), or the credibility of the source of a frame (Druckman 2001a; Druckman 2001b) may moderate the effects of framing. Numerous studies have demonstrated that public opinion is contingent upon, in essential and systematic ways, how issues are framed (Freedman 1997; Kinder and Sanders 1990; Mendelberg 2001; Nelson, Clawson and Oxley 1997; Nelson and Kinder 1996).

\section{Persuasive and Cueing Messages}

More specifically, Zaller's (1992) study of opinion formation describes two categories of political messages that offer theoretical guidance on the effect of reinforcing frames. Persuasive messages provide a reason for taking a position or point of view, while cueing messages provide information about the ideological implications of the persuasive information (Zaller 1992: 41-42). My experiment utilizes frames containing cueing messages, which enable people to relate the persuasive information they receive to their political predispositions, consequently preparing them to form opinions. Given ethnocentrism's prevalence in American public opinion, I expect to find that frames, which are consistent with, or reinforce, recipients' ethnocentric predispositions will activate ethnocentrism and fear across ethnocentric white participants, providing them with reason to support entering into conflict with Iran. Next, I examine the history of the ethnocentric framing of conflict in the Middle East, which will serve as a guide to the frames I create in the experiment. 
Historical Framing of Islam

Gerges' (2003: 75-76) historical analysis demonstrates that Americans' perceptions of Islam and the nature of threat from Islamic people underwent a radical shift in the 1970s, "largely because of the explosion of Islamic politics onto the scene." Several events "shocked many American officials into viewing Islam as a threat to Western interests" (Gerges 2003; Esposito 1983; Cottam 1990). ${ }^{10}$ Gerges notes that the 1973 Ramadan War was arguably fought under the banner of Islam, and that Libyan President Mu'ammar al Qaddafi employed Islamic symbols to legitimize his rule and spread Islamic "radicalism" and "terrorism" worldwide (Gerges 2003: 76). Labels such as "extremist," "terrorist," and "fanatical" were applied to the Islamic revolution and the Iran hostage crisis (Carter 1982: 12, 499, 506). The rebellious Islamists' takeover of the Grand Mosque at Mecca, the 1981 assassination of President Sadat of Egypt, and bloody attacks against U.S. personnel in Lebanon and Kuwait heightened concerns "over the export of Iranian 'fundamentalism'” (Brzezinski 1983: 484, 533; Esposito 1983: 21-22). Consequently, Americans polled in 1981 overwhelmingly indicated low opinions of Iran, and their attitudes of "anger," "hatred," "turmoil," and "troublesome country" indicated how "Iran's brand of revolutionary Islam overshadows much of the current U.S. debate about the rise of political Islam" (Gerges 2003: 78). When Americans were asked what comes to mind when the words "Muslim" or "Islam" are mentioned, the two most common responses were "Muhammad" and "Iran" (Slade 1981: 148-49, 157). This is not to say that Islam is seen as explicitly negative, but "security and strategic implications [are what] resonates in the minds of Americans" (Gerges 2003: 75). Samuel Lewis, former director of the State Department's Policy Planning Staff, acknowledges that the 
media's historically hostile coverage of 'extremist Islamist groups' reinforces American perception of Islam (Lewis 1995). As evidenced by the aforementioned polls, there is confusion between Islamic and Iranian politics, and the media's negative portrayal of Muslims has become an integral part of public consciousness (Slade 1981: 144-45, 147, $150,157)$

Merskin (2004: 157) asserts that shortly after the 9/11 attacks, President George W. Bush used rhetoric in his addresses to the nation, built on stereotyping words and images already established in over two decades of media and popular culture portrayals of Arabs as malevolent, murderous, and animalistic terrorists. These stereotypes tend to combine Arabs, Muslims, and Middle Easterners into a negative image of violence and danger, largely composed from collective memory, rather than from actual experience (2004: 158). Bush's addresses reflected an “identifiable model of enemy image construction" (2004: 158). Furthermore, ethnocentric frames employing activating terms (such as "us," "them," "they," "evil," and "those people") have continued to catalyze important human rights implications for Arab American citizens and noncitizens (Merskin 2004: 157). However, Venkatraman (2006: 7) explains that in its origin, the term "fundamentalism" has no direct negative or violent connotation, but is often applied to those who resort to violence based on the ideological or religious adherence. Only active fundamentalists and a select few use extreme measures to achieve their religious ideals, but the stereotyping of fundamentalists continues to be imposed on all of Islam (often incorrectly synonymized with Arab, Middle Eastern, Iran, etc.). 
With a historical perspective in hand, I now turn to a content analysis that demonstrates how these decades-old tactics are used to frame contemporary articles reporting on Iran's nuclear intentions.

\section{Contemporary Frames of Islam}

Kinder and Palfrey (1993: 46) suggest that, "perhaps public opinion depends in a systematic and intelligible way on how elites and institutions frame the issue," and that the best way to test such a claim is through experimentation. That is, "by examining the kinds of alterations in opinion that are induced by systematic alterations in the way that questions are... framed" (1993: 46). In this section, I examine the use of ethnocentric frames by the media. My intent is two-fold: to provide evidence that ethnocentric framing is prevalent and to create a model for the ethnocentric frames used in my experiment. The latter comes from the premise that, what is "imperative in such experiments is that alternative[s] ... be formulated in a way that faithfully mimics the ongoing debate among rival elites... so the natural process of political debate can be mimicked or reenacted" and studied. (1993: 46).

With the two aforementioned goals in mind, I examined news articles for evidence of ethnocentric framing of Iran's nuclear intentions, relevant to my framing experiment. At the least, the results of my content analysis were astonishing. Logically, since I am examining the effects of frames on American public opinion regarding the high-attention and salient Iran conflict, I examined major-circulation national newspapers. I focused my content analysis on the top fifteen newspapers by circulation in the United States (Audit Bureau of Circulation). ${ }^{11}$ Utilizing the practical LexisNexis Academic database, I searched those top American newspapers for the terms "United 
States," "Iran," "nuclear," and "threat," and retrieved 386 articles written between January 1, 2011 and January $31,2012 .{ }^{12}$ As a preliminary measure, I added the potentially stereotyping (ethnocentrism activating) terms "Islamic" or "Islam" to the search, and an impressive 284 of the articles remained. I also scanned the articles for potentially ethnocentric instances of "us," "them," "they," "we," and "those people." Upon closer examination of these articles, a number of tendencies appeared that evidenced ethnocentric frames at work.

The most striking findings in the content analysis are the strategic usages and placements of "Islam" and "Islamic"-and the findings are consistent across scores of articles. The terms are used in instances near the beginning, middle, and end of articles, and usually appear in sentences that portray the United States in some positive, diplomatic light and/or portray Iran and its government in a negative way. The statements using religious terms refer to the Islamic republic as defiant, punished, aspiring to build weapons, mocking, cruel, and hostile. The fact that most instances of "the Islamic republic" do not capitalize the proper name of the Iranian nation is quite diminutive of "them" in itself. Here are some examples:

1. “... Obama administration intensifies its diplomacy, Iran is showing little sign of bending to the will of its critics... the Islamic republic is believed headed toward having nuclear weapons capability in perhaps a few years estimates vary as to when" (Burns 2010).

2. "Iran denies that it is building a bomb. But the International Atomic Energy Agency (IAEA) ... censured the Islamic republic last year for secretly constructing a nuclear facility and defying U.N. resolutions on uranium enrichment" (Sheridan and Lynch 2010). 
3. "Although Obama has declined to rule out a military strike against Iran's nuclear sites to prevent the Islamic republic from building a nuclear weapon, the president has emphasized international diplomacy..." (DeYoung and Wilson 2012).

4. “The Islamic Republic seems justified in laughing off America's tough talk as the joke it is" (Dallas Morning News 2010).

5. "Iran has a record of arresting and convicting Americans suspected of spying... Mr. Hekmati's case was the first in the nearly 33-year history of estranged relations... in which Iran's Islamic authorities had ordered the execution of an American citizen" (Gladstone and Morris 2012).

6. "The Islamic republic also has warned of blocking one of the world's key tanker lanes, the Strait of Hormuz, in response to new, stronger U.S. economic penalties on Iran..." (Klapper and Burns 2012).

It is impossible to dismiss the placement of "Islam" and "Islamic" throughout the articles analyzed as anything less than subconscious, if not strategic, ethnocentric framing. While "The Islamic Republic of Iran" is the nation's official name, it is impossible to dismiss the tone of each sentence featuring the terms, as mentioned above. Again, in almost all instances of the phrase, "Islamic" is capitalized, while "republic" is not. Consider the first excerpt: President Obama is diplomatic, Iran is stubborn, and the "Islamic republic" is advancing toward nuclear capability. In the second excerpt: Iran denies building a bomb and last year the defiant "Islamic republic" was censured for secret construction of a nuclear facility. In the next selection, President Obama is portrayed as diplomatic and we are led to assume that the "Islamic republic" is building a nuclear weapon. In the fourth passage, Iran has nuclear ambitions, and the "Islamic Republic" is laughing at America for its inability to enforce its own sanctions. In the next excerpt, Iran's "Islamic authorities" executed an American citizen. Finally, in the last extract, "the Islamic republic" warns of blocking a world tanker lane. 
Contemporary Framing of " Us" and "Them"

The content analysis also reveals government leaders' and the media's enemy image construction and repetitive uses of activating terms such as "us," "them," "we," "they" and so forth, consistent with Merskin's analysis of Bush addresses. Consider the following examples:

1. "'Are they trying to develop a nuclear weapon? No,' Panetta said. 'But we know that they're trying to develop a nuclear capability. And that's what concerns us. And our red line to Iran is, 'Do not develop a nuclear weapon.' That's a red line for us and...we will respond to them'" (Puzzanghera 2012).

2. "An alleged Iranian plot to kill a Saudi ambassador in Washington shows that the ruling mullahs have no fear of the United States and that U.S. policy toward the Islamic republic must be more assertive... 'They don't believe we'd militarily respond and don't fear any sanctions we might throw at them,' Gerecht said" (Dorell 2011).

3. "The mistake with Iran is the tendency to think its leadership is rational... The country's leaders are Islamic fundamentalists who would surely kill any member of the Saudi royal family, custodians of the holy city of Mecca and fervid Sunnis all. The Iranians are just as fervid Shiites. They have many enemies... they oppress... and torture with abandon. In Iraq, the Iranians have gotten away with a proxy war against the U.S. If they indeed undertook that Washington operation, it's because they have achieved so much and paid for so little" (Cohen 2011).

4. Dennis B. Ross, who managed Iran policy on the National Security Council staff until November, said: 'The sanctions all along have been designed to put the Iranians in a position where they had to make a choice, and if they did not make a choice, that they realize the price for not doing so would be high. ... They are absorbing a price now that they themselves do not want to absorb.'

President Mahmoud Ahmadinejad dismissed international concern... calling it 'a joke... It's clear they're afraid of our development'" (DeYoung and Wilson 2012).

In the first excerpt, current United States Secretary of Defense Leon Panetta speaks sternly about the American stance on Iranian nuclear capability, using terms like 
"they," "we," "they're" "us," "our" and "them," which clearly define the line between the enemy and "us." The second passage is indeed a great example from the analysis, as Iranians are implicated in a plot and "the Islamic republic" is portrayed as having no fear of or respect for the United States and a former CIA officer constructs Iran as the enemy through his use of ethnocentric activators-"they," "we'd," "we" and "them." The third passage is loaded in much the same way, as the writer assertively portrays Iran as a nation led by irrational, murderous, oppressive, torturous, and fervid "Islamic fundamentalists" with many enemies. In the final excerpt, a Security Council staff member repeatedly refers to the Iranians as "they," and selectively quotes Iranian President Ahmadinejad doing much the same.

In this chapter, I have presented a substantive review of the literature on ethnocentrism and media framing, providing for the theoretical and general assumptions of this framing experiment. I have provided a historical analysis that implicates American officials and the American media for decades of consequential enemy image construction through stereotypes and rhetoric. Most importantly, a thorough content analysis reveals these tactics are still employed today, by the nation's largest news print outlets. These findings provide a preliminary legitimization for the undertaking of my experiment and serve as a model for the frames I create. The next section analyzes ethnocentrism as a predictor of support for war over time, focused on the effects of ethnocentrism across race. Through this analysis, I build a case for understanding the significance of ethnocentrism's effects through the lens of the issue-attention cycle. I demonstrate just how significant ethnocentrism is in predicting support for war at its onset. This is a crucial finding, as my experiment later demonstrates that frames like the ones cited above 
activate ethnocentrism and fear. Together, these findings establish a causal link between the media's employment of ethnocentric frames and the effectiveness of those frames in generating support across whites. 


\section{CHAPTER III}

\section{ETHNOCENTRISM'S SIGNIFICANCE IN}

\section{PREDICTING SUPPORT FOR WAR ACROSS TIME AND RACE}

Before conducting my framing experiment, with differences across race in mind, revisiting Kinder's and Kam's analysis of the war on terror was the first order of business. Using the 2000-2002 ANES Panel, they analyzed the activation of ethnocentrism after $9 / 11$ and its subsequent effects on support for the war on terror. While the authors demonstrated ethnocentrism to be a significant predictor of support in several cases, the issue of support across race was perhaps put aside for future study. As previously mentioned, Kinder and Kam demonstrated whites to be generally more ethnocentric than blacks, as expressed through 2000 ANES stereotype measures (2007: 324) and before proceeding with my experiment, I examined ethnocentrism across race as it underlies their more recent analysis of the war on terror, and in subsequent 2004 and 2008 ANES studies. In some cases, at the onset of war, I found that support is so high that the effects of ethnocentrism are overshadowed - almost everyone supports the measure, so ethnocentrism is not a statistically significant predictor. Nevertheless, when support is not universal, but is strong, ethnocentrism is a reliably significant predictor of support for war at its onset- across whites almost exclusively. However, through this analysis, a trend of waning support for the wars emerges, accompanied by a trend of decreasing significance of the effect of ethnocentrism on public support. The wars dragged on, attention and threat decreased, lives were lost, domestic conspiracy theories 
circulated, and ethnocentrism became less significant in predicting attitudes about war as the conflicts became increasingly unpopular. Through this portion of my analysis, I demonstrate that ethnocentrism a stable and significant predictor of support for war at the onset across white individuals, and I build a case for the effectiveness of examining the long-run effects of ethnocentrism through Downs' (1972) issue-attention cycle.

\section{Ethnocentrism in White and Black-2000-2002}

Beginning with the reexamination of ethnocentrism's implications for support for the war on terror, I present my race analysis in three tables (protecting the homeland, going to war, and backing the president) as did Kinder and Kam (2009: 81-82). As I began to duplicate their analyses, a preliminary look at the frequency distributions of ethnocentrism across race produced similar statistics to those reported in their 2007 article. The distribution of white ethnocentrism is centered higher, the minimum value is more ethnocentric in the white distribution than in the black distribution, and a white individual represents the maximum score on the entire $E$-scale ${ }^{13}$. These results are found in Table 3.1 below. Figure 1 and Figure 2 illustrate how the white distribution is centered in the range of ethnocentrism and skews toward in-group favoritism.

\begin{tabular}{|c|c|c|c|}
\hline \multicolumn{4}{|c|}{ Table 3.1 $\mid$ Ethnocentrism in 2000} \\
\hline & All Groups & Whites & Blacks \\
\hline Mean & 0.08 & 0.09 & -0.02 \\
\hline St. Dev & 0.15 & 0.15 & 0.14 \\
\hline Range & $(-0.61,0.94)$ & $(-0.33,0.94)$ & $(-0.61,0.56)$ \\
\hline $\mathbf{N}$ & 1353 & 1129 & 141 \\
\hline
\end{tabular}


Figure 1 | Black Ethnocentrism in 2000

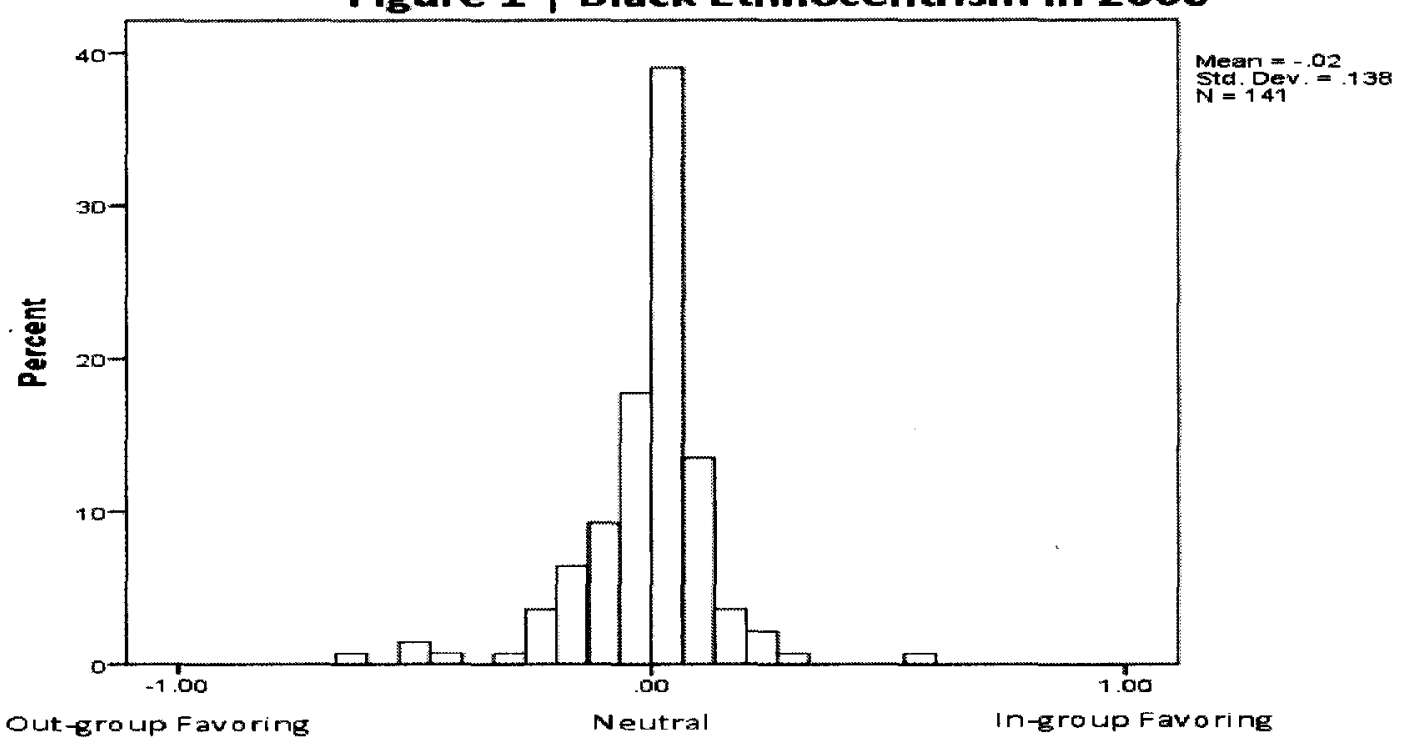

Figure 2 | White Ethnocentrism in 2000

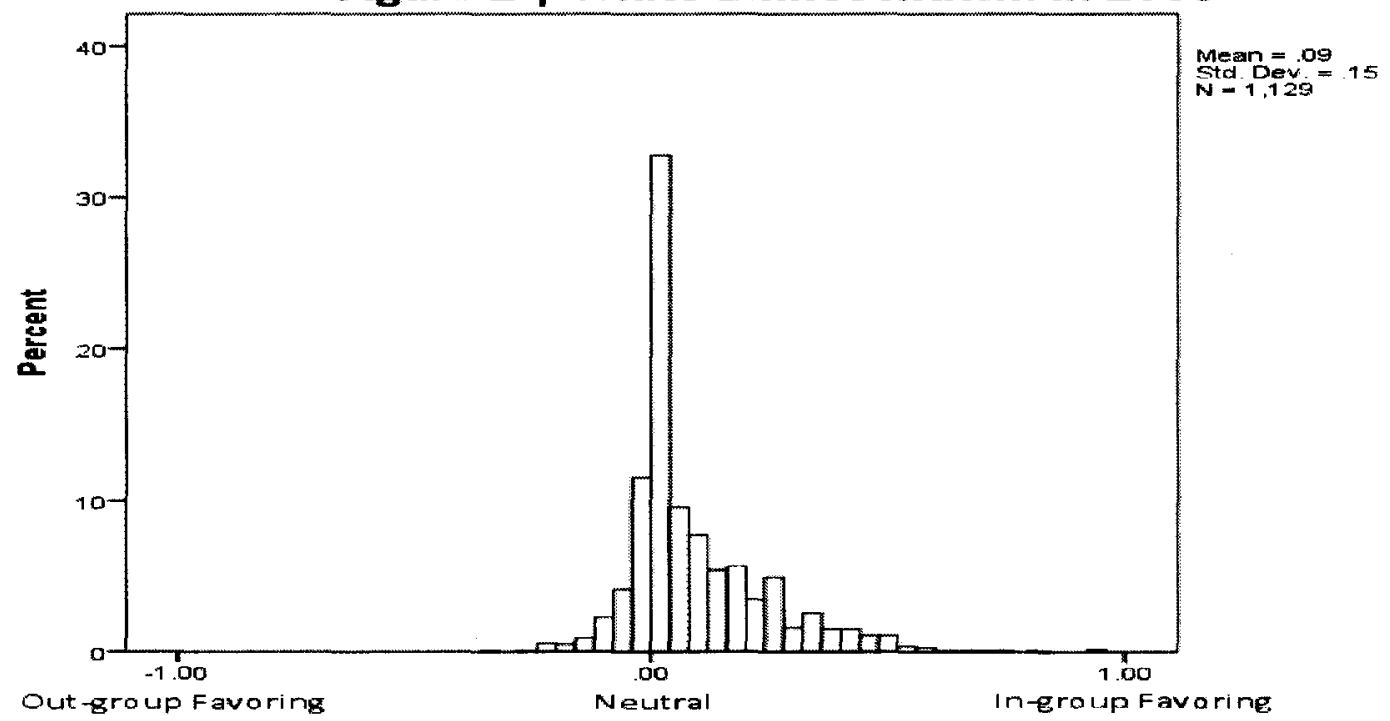

I proceed with my race analysis using ordered probit regression. ${ }^{14} \mathrm{I}$ do not apply controls for any race, but begin by analyzing American ethnocentrism, and then subsample the results in white, and finally in black. Regression models control for partisanship ${ }^{15}$, education ${ }^{16}$, perception of threat ${ }^{17}$, political awareness ${ }^{18}$, and gender ${ }^{19}$. In the models of support for the president, I also use controls for household ${ }^{20}$ and national economic conditions, ${ }^{21}$ following the result that a president's popularity hinges on 
economic conditions (Kinder and Kam 2009: 273, note 10). ${ }^{22}$ I repeat these same procedures using similar variables in the 2004 and 2008 ANES studies.

\section{Ethnocentrism and Support for War in Black and White-2002}

Support for Protecting the Homeland in Black and White--2002

Following the line of thought driving my hypothesis, I expected to find that ethnocentrism was more significant in predicting support for defending the homeland across white respondents than black respondents. The results are astounding. Using the 2000-2002 ANES Panel, Kinder and Kam found American ethnocentrism to be a significant predictor of support for increased spending on the war on terror ${ }^{23}$, border control $^{24}$, and national defense ${ }^{25}$. My race analysis reveals that ethnocentrism across white respondents is a significant predictor of support for increased spending to protect the homeland, across all variables. White Republicans were likely to support increased spending, as were whites who felt threatened. Interestingly, ethnocentrism is insignificant in predicting support for spending on homeland security ${ }^{26}$, but becomes significant when it is subsampled for white. Ethnocentrism is insignificant in predicting support in all cases among blacks. At the onset of the wars, support for increased spending was strong. My sample reflects just that, as $63 \%$ of respondents supported increasing spending on the war on terrorism, including $62 \%$ of whites and $57 \%$ of blacks. Across all respondents, $73 \%$ supported increased spending on border control, including $73 \%$ of whites and $65 \%$ of blacks. Across all respondents, $59 \%$ supported increased defense spending, inclusive of $59 \%$ of white respondents and $51 \%$ of black respondents. Ethnocentrism, particularly white ethnocentrism, was driving support for increased spending to protect the homeland. 


\begin{tabular}{|c|c|c|c|c|c|c|c|c|}
\hline \multicolumn{9}{|c|}{$\begin{array}{c}\text { Table 3.2 | Ethnocentrism and support across race for the war on terrorism: } \\
\text { Protecting the homeland }\end{array}$} \\
\hline & \multicolumn{2}{|c|}{ War on Terror } & \multicolumn{2}{|c|}{ Home. Sec. } & \multicolumn{2}{|c|}{ Border Ctrl. } & \multicolumn{2}{|c|}{ Nat'l Defense } \\
\hline Ethnocentrism & $\begin{array}{c}\text { White } \\
1.62^{* * *} \\
(0.53) \\
{[0.00]}\end{array}$ & $\begin{array}{c}\text { Black } \\
1.70 \\
(2.28) \\
{[0.46]}\end{array}$ & $\begin{array}{l}\text { White } \\
0.93^{*} \\
(0.53) \\
{[0.08]}\end{array}$ & $\begin{array}{l}\text { Black } \\
-1.00 \\
(1.64) \\
{[0.54]}\end{array}$ & $\begin{array}{c}\text { White } \\
1.27^{* * *} \\
(0.40) \\
{[0.00]}\end{array}$ & $\begin{array}{c}\text { Black } \\
-0.24 \\
(1.18) \\
{[0.84]}\end{array}$ & $\begin{array}{l}\text { White } \\
0.81^{* *} \\
(0.35) \\
{[0.02]}\end{array}$ & $\begin{array}{c}\text { Black } \\
0.88 \\
(1.09) \\
{[0.42]}\end{array}$ \\
\hline Partisanship & $\begin{array}{c}-0.77^{* * *} \\
(0.19)\end{array}$ & $\begin{array}{c}1.43 \\
(0.95)\end{array}$ & $\begin{array}{c}-0.40^{* *} \\
(0.20)\end{array}$ & $\begin{array}{l}-0.40 \\
(1.01)\end{array}$ & $\begin{array}{c}-0.46^{* * *} \\
(0.14)\end{array}$ & $\begin{array}{c}0.35 \\
(0.63)\end{array}$ & $\begin{array}{c}-1.04^{* * *} \\
(0.14)\end{array}$ & $\begin{array}{c}0.25 \\
(0.60)\end{array}$ \\
\hline Education & $\begin{array}{r}-0.76 \\
(0.28)\end{array}$ & $\begin{array}{l}-1.05 \\
(1.25)\end{array}$ & $\begin{array}{c}0.45 \\
(0.30)\end{array}$ & $\begin{array}{l}-0.44 \\
(1.05)\end{array}$ & $\begin{array}{c}-0.55^{* * *} \\
(0.21)\end{array}$ & $\begin{array}{c}0.66 \\
(0.71)\end{array}$ & $\begin{array}{l}-0.22 \\
(0.19)\end{array}$ & $\begin{array}{r}-0.59 \\
(0.66)\end{array}$ \\
\hline Threat & $\begin{array}{l}0.80 * * * \\
(0.25)\end{array}$ & $\begin{array}{c}0.16 \\
(0.66)\end{array}$ & $\begin{array}{c}0.27 \\
(0.26)\end{array}$ & $\begin{array}{c}0.37 \\
(0.76)\end{array}$ & $\begin{array}{c}0.48^{* * * *} \\
(0.19)\end{array}$ & $\begin{array}{c}0.61 \\
(0.45)\end{array}$ & $\begin{array}{c}0.47 * * * \\
(0.17)\end{array}$ & $\begin{array}{c}0.65 \\
(0.43)\end{array}$ \\
\hline $\mathbf{N}$ & $\begin{array}{l}\text { Total } \\
\text { White } \\
\text { Black }\end{array}$ & $\begin{array}{c}443 \\
385 \\
35\end{array}$ & $\begin{array}{l}\text { Total } \\
\text { White } \\
\text { Blac }\end{array}$ & $\begin{aligned} & 398 \\
= & 342 \\
= & 36\end{aligned}$ & $\begin{array}{l}\text { Total } \\
\text { White } \\
\text { Black }\end{array}$ & $\begin{array}{l}846 \\
732 \\
71\end{array}$ & $\begin{array}{l}\text { Total } \\
\text { White } \\
\text { Black }\end{array}$ & $\begin{array}{l}843 \\
729 \\
71\end{array}$ \\
\hline $\begin{array}{l}\text { Entries are orde } \\
\text { control for polit } \\
* * * p<0.01 ; \\
\text { Source: } 2000-20\end{array}$ & $\begin{array}{l}\text { obit reg } \\
\text { warenes } \\
0.05 ; \mathrm{p}< \\
\text { merican }\end{array}$ & $\begin{array}{l}\text { sion coe } \\
\text { nd gend } \\
10 ; p-v \text { s } \\
\text { ational } \mathrm{E}\end{array}$ & $\begin{array}{l}\text { ients } w \\
\text { s for etl } \\
\text { tion Stu }\end{array}$ & $\begin{array}{l}\text { standa } \\
\text { ocentris } \\
\text { Panel }\end{array}$ & $\begin{array}{l}\text { rrors in } \mathrm{p} \\
\text { re in brac }\end{array}$ & $\begin{array}{l}\text { enthes } \\
\text { ts. }\end{array}$ & ow. Mo & \\
\hline
\end{tabular}

Support for Going to War in Black and White-2002

Ethnocentrism in black and white also yielded interesting results in my analysis of support for going to war in Afghanistan ${ }^{27}$ and in Iraq ${ }^{28}$. As did Kinder and Kam, I found American ethnocentrism to be insignificant in predicting support for going to war against the Taliban in Afghanistan. Perhaps ethnocentrism's failure here, particularly across whites, is due to the vast popularity of the policy (at that time), or the contrasting appeals of military intervention (to the ethnocentric) and liberation (to the not so ethnocentric). In fact, an astounding $84 \%$ of respondents in 2002 expressed that war in Afghanistan was worth it $-87 \%$ of whites. The Taliban had been driven from their strongholds in Kandahar and Kabul (PBS.org 2010), enabling the new Afghan government to raise its flag over the presidential palace, engage in international conversations as a sovereign nation, and begin building a national army. Meanwhile, the United States and its allies were chasing the Taliban and al-Qaeda into the hills of Afghanistan, pursuing bin Laden 
and top al-Qaeda officials, and seeking retribution for the still-fresh $9 / 11$ attacks. And almost all whites supported the war and its early successes. Comparatively, only $56 \%$ of blacks felt going to Afghanistan was worth it. Ethnocentric blacks, that is, supported going to Afghanistan - this is one of only three instances that black ethnocentrism is a more significant predictor than white ethnocentrism in all analyses.

Ethnocentrism is found to be a significant predictor of support for military action in Iraq just prior to the March 2003 invasion. White ethnocentrism is a significant predictor, while black ethnocentrism is not. Again, white Republicans were likely to support military action in Iraq, as were whites who felt threatened. Here, I began to see a trend that whites are more ethnocentric and their ethnocentrism drove support for war. More importantly, in 2002 , we see that ethnocentrism readies white individuals for war.

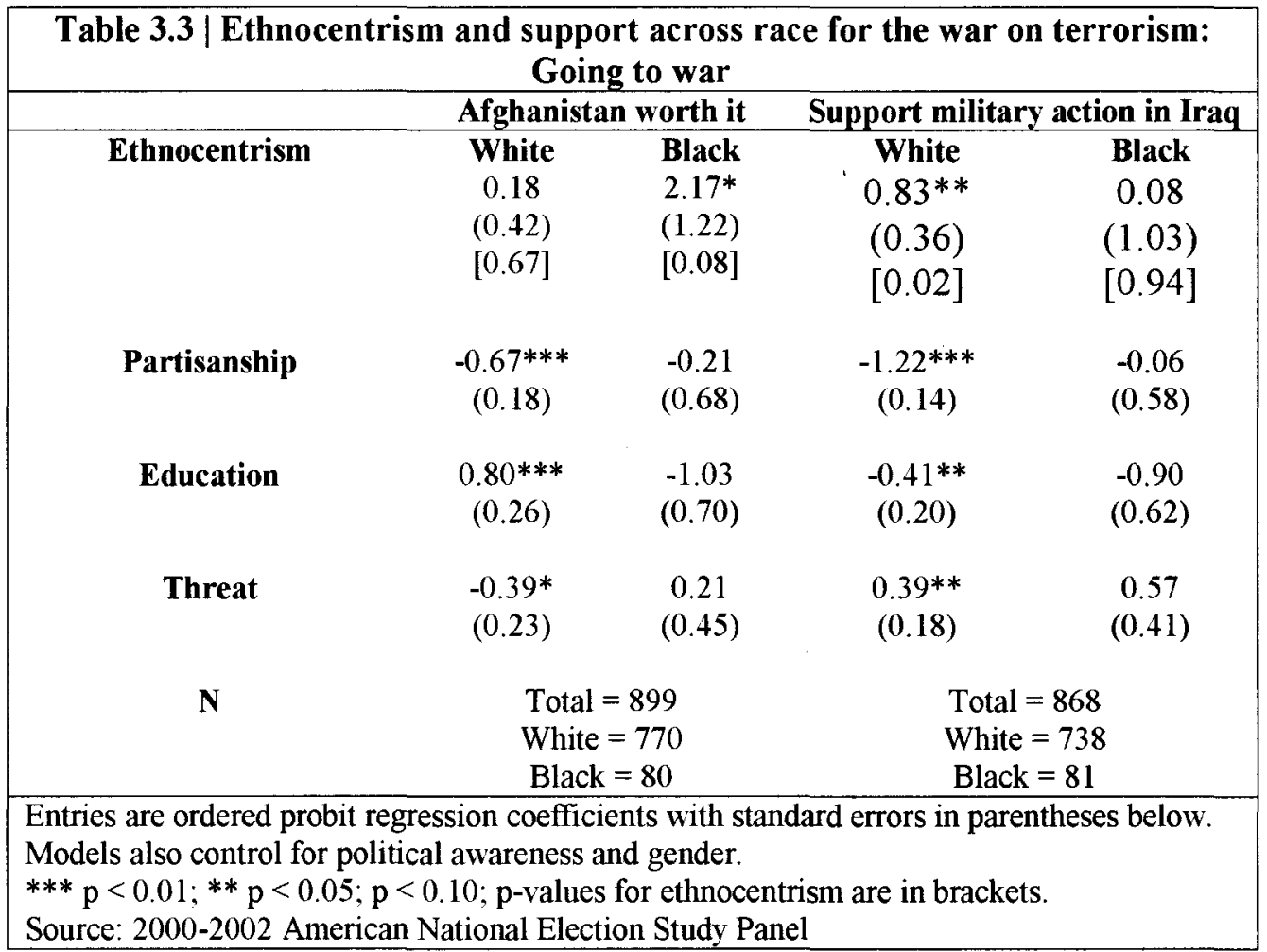

There was still no confirmation that Hussein had weapons at this time, but across whites, ethnocentrism caused fear and suspicion of Hussein harboring weapons and terrorist- 
and ethnocentric whites were ready for war. Across white respondents, $61 \%$ supported military action, compared to only $35 \%$ of black respondents.

Support for the President in Black and White-2002

The story remains much the same in my analysis of ethnocentrism's effects on support for the president. Kinder and Kam find American ethnocentrism to be a significant predictor of approval for Bush's general performance ${ }^{29}$ and approval for the president's handling of the war on terror ${ }^{30}$ and $9 / 11^{31}$. Ethnocentrism across white individuals is significant in predicting support for Bush's handling of $9 / 11$, while black ethnocentrism does not significantly predict any measure of support for the president. White respondents' approval of the president was remarkably high in 2002. White Republicans were significantly more likely to support Bush. Again, I suspect that levels of overwhelming white support are masking ethnocentrism as a significant predictor of approval for Bush's general performance and handling of the war on terror. Bush delivered powerful messages in the days after $9 / 11^{32}$, and his stern public remarks resonated with whites. Across white respondents, $75 \%$ and $81 \%$ approved of the president's general performance and handling of the war on terror, respectively. Black respondents approved of the president on these measures at $40 \%$ and $44 \%$, respectively. The complete results of the race analysis of ethnocentrism's effects on backing the president are presented in Table 3.4 below. 


\begin{tabular}{|c|c|c|c|c|c|c|}
\hline & \multicolumn{2}{|c|}{ General performance } & \multicolumn{2}{|c|}{ War on terror } & \multicolumn{2}{|c|}{ Handling 9/11 } \\
\hline Ethnocentrism & $\begin{array}{c}\text { White } \\
0.06 \\
(0.44) \\
{[0.89]}\end{array}$ & $\begin{array}{c}\text { Black } \\
1.37 \\
(1.50) \\
{[0.36]}\end{array}$ & $\begin{array}{l}\text { White } \\
0.63 \\
(0.63) \\
{[0.32]}\end{array}$ & $\begin{array}{c}\text { Black } \\
1.95 \\
(1.99) \\
{[0.33]}\end{array}$ & $\begin{array}{c}\text { White } \\
1.98^{* * *} \\
(0.71) \\
{[0.00]}\end{array}$ & $\begin{array}{c}\text { Black } \\
4.35 \\
(2.88) \\
{[0.13]}\end{array}$ \\
\hline Partisanship & $\begin{array}{c}-1.89 * * * \\
(0.18)\end{array}$ & $\begin{array}{l}-1.34 \\
(0.72)\end{array}$ & $\begin{array}{c}-1.22 * * * \\
(0.24)\end{array}$ & $\begin{array}{c}0.77 \\
(1.20)\end{array}$ & $\begin{array}{c}-0.79 * * * \\
(0.27)\end{array}$ & $\begin{array}{l}-0.45 \\
(1.19)\end{array}$ \\
\hline Educátion & $\begin{array}{l}-0.07 \\
(0.25)\end{array}$ & $\begin{array}{l}-0.57 \\
(0.80)\end{array}$ & $\begin{array}{c}0.43 \\
(0.34)\end{array}$ & $\begin{array}{l}-2.21 \\
(1.25)\end{array}$ & $\begin{array}{c}0.07 \\
(0.37)\end{array}$ & $\begin{array}{l}-1.24 \\
(1.54)\end{array}$ \\
\hline Threat & $\begin{array}{c}0.25 \\
(0.22)\end{array}$ & $\begin{array}{l}-0.45 \\
(0.52)\end{array}$ & $\begin{array}{c}0.26 \\
(0.30)\end{array}$ & $\begin{array}{c}0.03 \\
(0.70)\end{array}$ & $\begin{array}{l}-0.26 \\
(0.33)\end{array}$ & $\begin{array}{r}-0.47 \\
(0.87)\end{array}$ \\
\hline $\mathbf{N}$ & $\begin{array}{l}\text { Tota } \\
\text { Whit } \\
\text { Blac }\end{array}$ & & $\begin{array}{l}\text { Total } \\
\text { White } \\
\text { Black }\end{array}$ & & $\begin{array}{l}\text { Tota } \\
\text { Whit } \\
\text { Blac }\end{array}$ & \\
\hline $\begin{array}{l}\text { Entries are ordered } \mathrm{p} \\
\text { control for political a } \\
*^{* *} \mathrm{p}<0.01 ; * * \mathrm{p}< \\
\text { Source: } 2000-2002 \text { A }\end{array}$ & $\begin{array}{l}\text { ression ce } \\
\text { s. gender, } \\
<0.10 ; \\
\text { National }\end{array}$ & $\begin{array}{l}\text { ients wi } \\
\text { househo } \\
\text { ues for o } \\
\text { tion Stu }\end{array}$ & $\begin{array}{l}\text { ndard erro } \\
\text { d national } \\
\text { entrism ar } \\
\text { nel. }\end{array}$ & $\begin{array}{l}\text { n parent } \\
\text { nomic e } \\
\text { bracke }\end{array}$ & $\begin{array}{l}\text { elow. M } \\
\text { ions. }\end{array}$ & $S$ also \\
\hline
\end{tabular}

\section{Ethnocentrism and Support for War in Black and White-2004}

In the 2004 race analysis of ethnocentrism, I again first examined the $E$-scale ${ }^{33}$ distributions of American, white, and black ethnocentrism. I found the distribution to be quite similar to the 2000-2002 ANES panel distribution. Whites were still much more ethnocentric than blacks, as the maximum score for a white respondent is more than twice the maximum score for a black respondent, and the mean score for whites is nearly 0.05 higher than the mean score for blacks. Descriptives of the distributions of American, white, and black ethnocentrism are presented in Table 3.5 below. Figure 3 and Figure 4 help to illustrate the differences in ethnocentrism across race. As in the previous analysis, I apply this initial description of the distribution of ethnocentrism across race to analyze support for war. Again, models control for partisanship ${ }^{34}$, education ${ }^{35}$, perception of 
threat $^{36}$, gender, political awareness ${ }^{37}$, and in evaluations of the president, household ${ }^{38}$ and national ${ }^{39}$ economic evaluations.

\begin{tabular}{|c|c|c|c|}
\hline \multicolumn{4}{|c|}{ Table 3.5 | Ethnocentrism in 2004} \\
\hline & All Groups & Whites & Blacks \\
\hline Mean & 0.06 & 0.06 & 0.02 \\
\hline St. Dev & 0.14 & 0.14 & 0.13 \\
\hline Range & $(-0.74,0.89)$ & $(-0.74,0.89)$ & $(-0.50,0.37)$ \\
\hline $\mathbf{N}$ & 951 & 730 & 140 \\
\hline
\end{tabular}

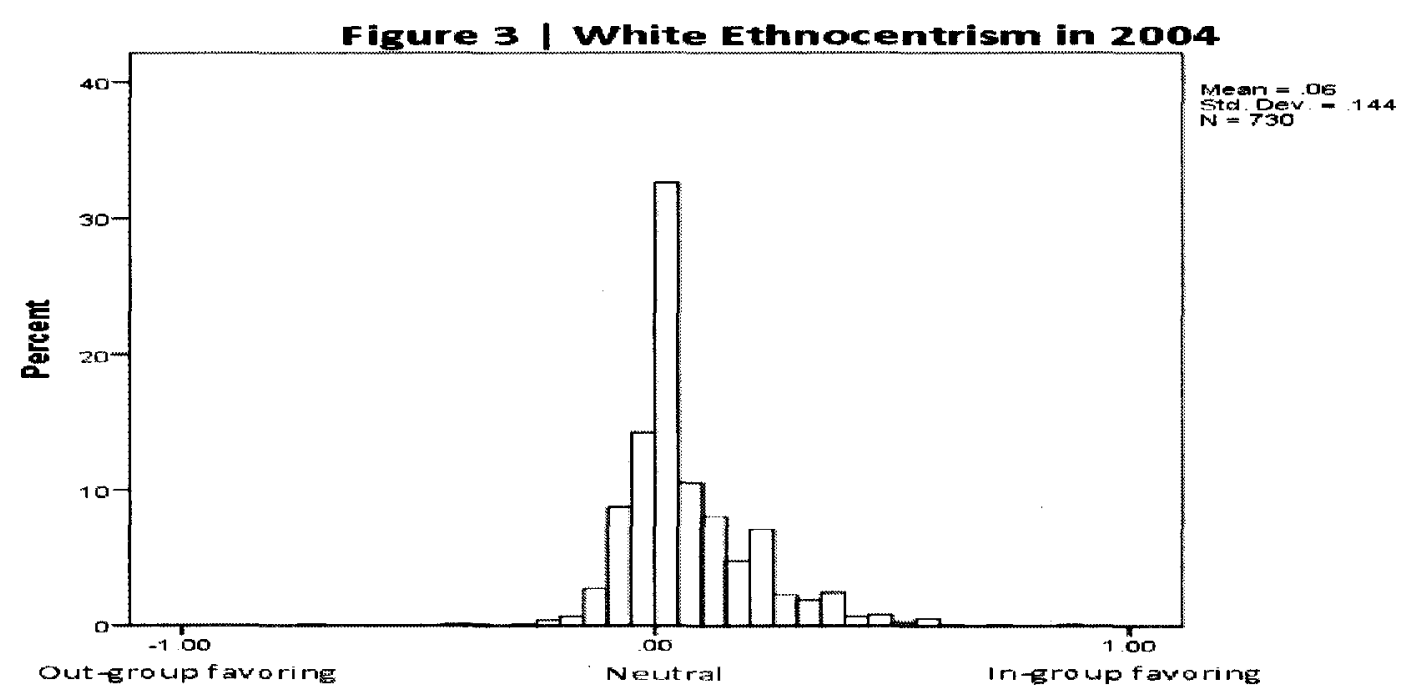

Figure 4 | Black Ethnocentrism in 2004

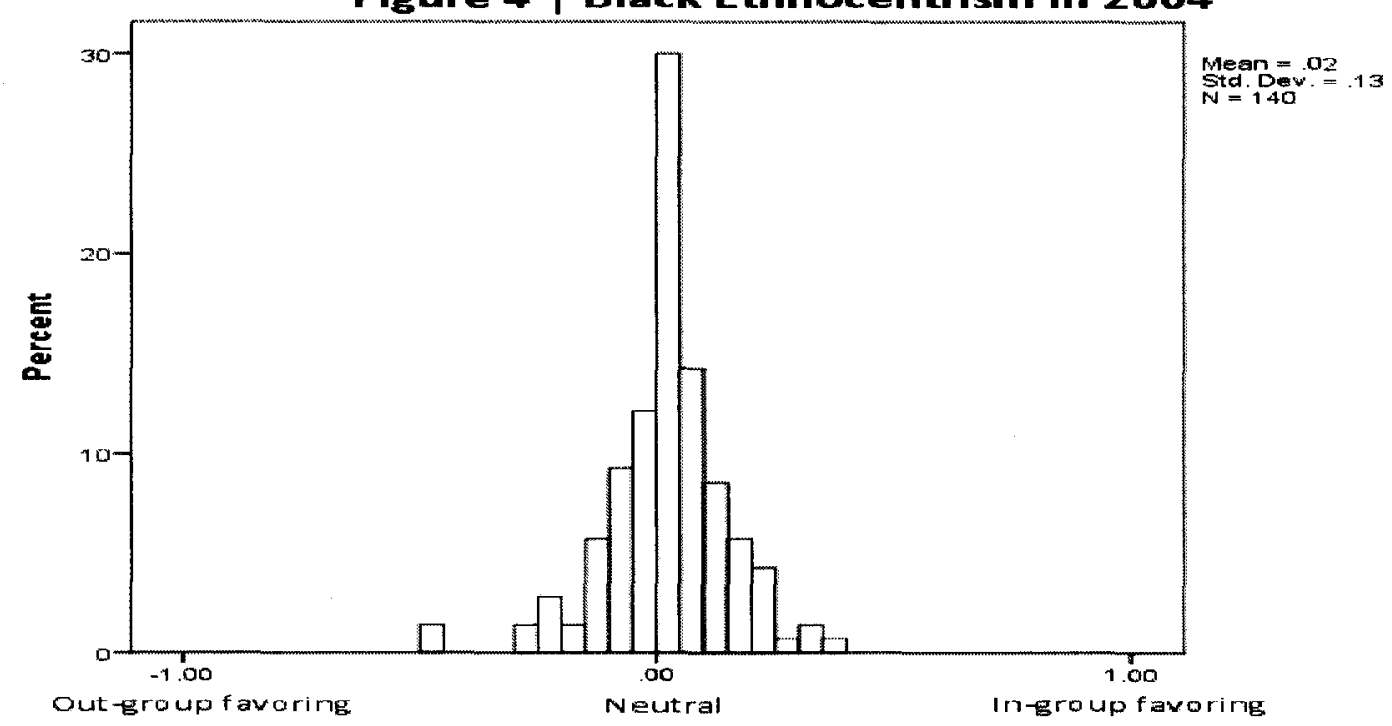


Support for Protecting the Homeland in Black and White-2004

In Table 3.6 below the race analysis of support for spending on homeland security is omitted, as no comparable variables were found in the 2004 ANES. It is through this 2004 analysis of spending support that I suggest the framework of the issue-attention cycle becomes important in understanding ethnocentrism (and corresponding perception of threat or fear) and support for conflict. The effects of ethnocentrism and fear begin to diminish over time, while partisanship and higher rates of education become more stable predictors of support. In fact, as evidenced by the regression, perception of threat had begun to discourage support for spending in 2004. The regression output demonstrates that ethnocentrism is significant in predicting support for increased spending on the war on terror ${ }^{40}$ and on border control ${ }^{41}$. The ethnocentrism coefficients were significant for whites, as well. The war and border security spending measures inherently cause "us" and "them" thinking—keeping "us" safe at home and fighting "they" who attacked us. I argue that ethnocentrism's significance in predicting support for increased spending on the war complements its lack of effect on support for defense spending ${ }^{42}$. No weapons had been discovered in Iraq, Saddam was out of power, and Americans thought that economic and military interests should be refocused on fighting terrorists. As I will demonstrate shortly, ethnocentrism becomes insignificant in predicting support for going to war in Iraq. Per the issue-attention cycle framework, Americans were realizing the costs of occupying Iraq and keeping security forces in place. Perceptions of "another Vietnam" and displeasure with the effort against the terrorists had Americans beginning to think about change or coming home—not about "us" and "them." 


\begin{tabular}{|c|c|c|c|c|c|c|}
\hline $\begin{array}{r}\text { Tab } \\
\text { for the }\end{array}$ & $\begin{array}{l}.6 \mid \text { Eth } \\
\text { on terr }\end{array}$ & $\begin{array}{l}\text { cent } \\
\text { ism }\end{array}$ & $\begin{array}{l}1 \text { and si } \\
\text { 004: Pr }\end{array}$ & $\begin{array}{l}\text { ort a } \\
\text { cting }\end{array}$ & $\begin{array}{l}\text { Ss race } \\
\text { homela }\end{array}$ & \\
\hline & War on & error & Border & ontrol & National & efense \\
\hline Ethnocentrism & White & Black & White & Black & White & Black \\
\hline & $0.89 * * *$ & -0.29 & $2.13^{* * *}$ & -0.77 & 0.47 & $-1.44^{*}$ \\
\hline & $(0.32)$ & $(0.78)$ & $(0.41)$ & $(0.80)$ & $(0.31)$ & $(0.78)$ \\
\hline & {$[0.01]$} & {$[0.71]$} & {$[0.00]$} & {$[0.33]$} & {$[0.13]$} & {$[0.06]$} \\
\hline Partisanship & $-0.76^{* * *}$ & -0.18 & $-0.34 *$ & $-0.97 *$ & $-1.44 * * *$ & 0.17 \\
\hline & $(0.16)$ & $(0.56)$ & $(0.19)$ & $(0.58)$ & $(0.21)$ & $(0.54)$ \\
\hline Education & -0.16 & -0.33 & $-0.75 * * *$ & 0.44 & $-0.72 * * *$ & -0.31 \\
\hline & $(0.17)$ & $(0.40)$ & $(0.20)$ & $(0.40)$ & $(0.17)$ & $(0.39)$ \\
\hline Threat & $-0.12 * *$ & 0.01 & -0.05 & -0.14 & $-0.15 * * *$ & 0.06 \\
\hline & $(0.06)$ & $(0.14)$ & $(0.07)$ & $(0.15)$ & $(0.06)$ & $(0.14)$ \\
\hline $\mathbf{N}$ & Total & 925 & Total & 926 & Tota & 835 \\
\hline & White & 710 & White & 713 & White & 651 \\
\hline & Black & 136 & Black & 134 & Black & 112 \\
\hline $\begin{array}{l}\text { Entries are order } \\
\text { parentheses belo } \\
* * * \mathrm{p}<0.01 ; * * \\
\text { Source: } 2004\end{array}$ & $\begin{array}{l}\text { robit reg } \\
\text { Models al } \\
0.05 ; \mathrm{p} \\
\text { can Natic }\end{array}$ & $\begin{array}{l}\text { ssion } \\
\text { cont } \\
10 ; \mathrm{p} \\
\text { al Ele }\end{array}$ & $\begin{array}{l}\text { icients } \\
\text { r politic } \\
\text { les for e } \\
\text { Study. }\end{array}$ & $\begin{array}{l}\text { h stand } \\
\text { awaren } \\
\text { ocentr }\end{array}$ & $\begin{array}{l}\text { errors in } \\
\text { and gen } \\
\text { are in b }\end{array}$ & ts. \\
\hline
\end{tabular}

Support for Going to War in Black and White-2004

In the 2004 race analysis of support for going to war (Table 3.7), I use a variable measuring whether respondents felt that going to war in Iraq ${ }^{43}$ was "worth it," in order to continue my examination of ethnocentrism's significance in predicting American support for U.S. military action in Iraq. Ethnocentrism was no longer a significant predictor of support for going to war in Iraq, which had already begun to grown unpopular. Only $41 \%$ of respondents still supported the war in Iraq, including only $46 \%$ of whites and a mere $18 \%$ of blacks-all decreases of roughly $15 \%$. Retaliating against our attackers in Afghanistan was still extremely popular, but had already begun to lose popularity as bin Laden had yet been captured. Across all respondents, $72 \%$ still supported going to war in Afghanistan ${ }^{44}-79 \%$ of whites and $42 \%$ of blacks. Again, I suspect that extremely high support for the war in Afghanistan, especially across whites, overshadows the effect of ethnocentrism. As for Iraq support, consistent with the issue-attention cycle framework, 
extended troop presence, a longing for better focus in Afghanistan, and disapproval with the military strategy abroad began to replace the ethnocentric thinking that fueled American support at the war's onset. Still, white Republicans were significantly likely to support going to war, and again, those who were likely to feel fearful were less likely to support war.

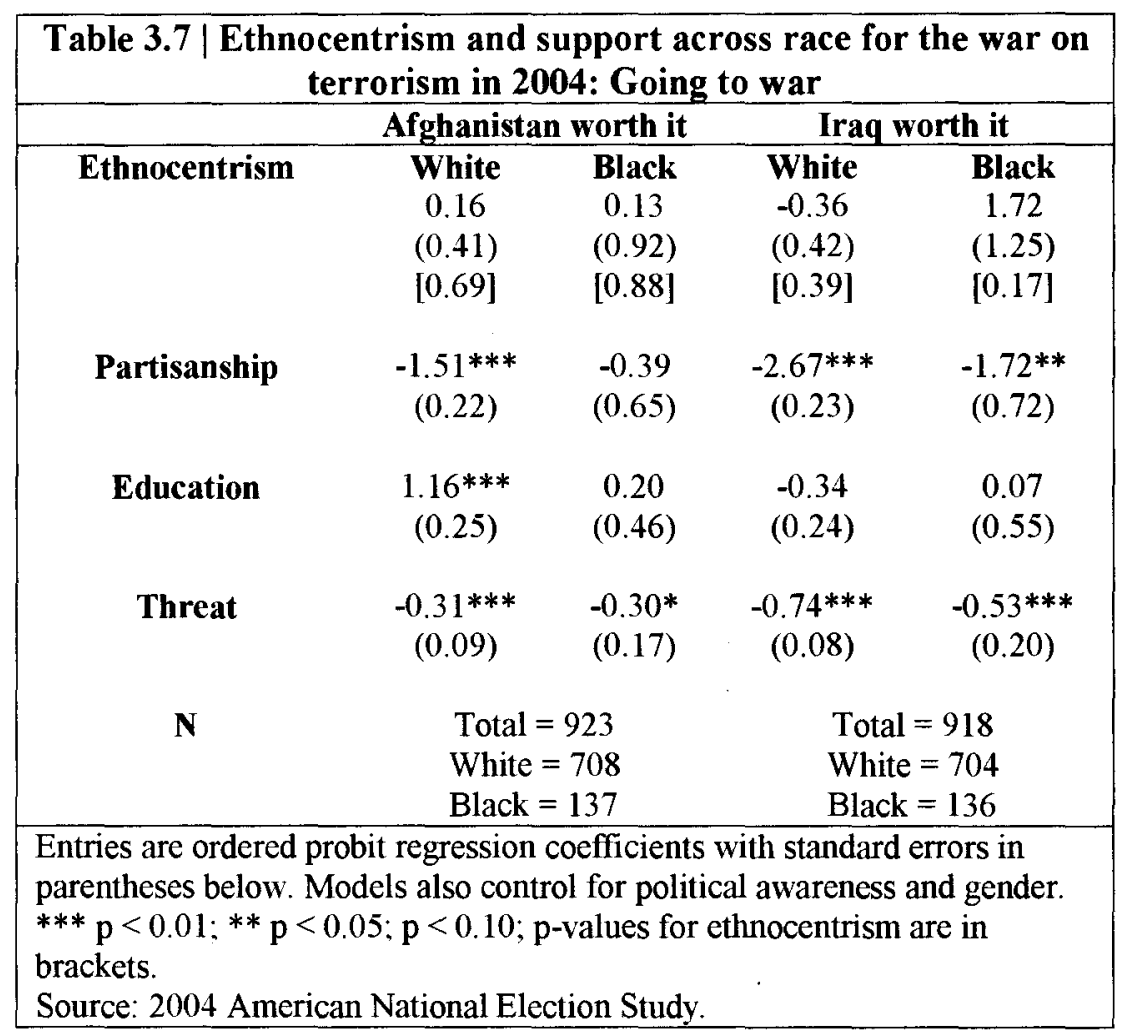

Support for the President in Black and White-2004

Table 3.8 continues to demonstrate ethnocentrism's shift to insignificance in predicting support for war in 2004. As support for Bush continued to diminish due to concerns about the military's focus in the Middle East, so too did approval of Bush's handling of the war on terror ${ }^{45}$. Ethnocentrism was no longer a significant predictor, as I suggest, due to decreasing attention, interest, and support stemming from the previously discussed domestic frustration. I do find ethnocentrism to be significant in predicting 
support for Bush's general performance ${ }^{46}$ and handling of Iraq ${ }^{47}$ across blacks - the other instances of black ethnocentrism's significance. With only $22 \%$ of black respondents approving of Bush's general performance, and only $16 \%$ approving of Bush's handling of Iraq, I propose that these findings are due to the fact that largely only ethnocentric blacks supported Bush. Nevertheless, public approval for the president had sharply declined by 2004. I propose that the costs of the wars and perceptions of slow progress in those wars caused a shift in ethnocentric thinking, refocusing American public opinion on war-cost evaluations of the president. By 2004 , only $53 \%$ of respondents approved of Bush's general performance, and only $56 \%$ approved of his handling of the war on terror-down nearly $20 \%$ from two years before. The decreases were much the same across white and black respondents. Whites approved of Bush's performance on the two measures at $59 \%$ and $61 \%$ respectively, while only $22 \%$ of blacks approved of his general performance and only $28 \%$ approved of his handling of the war on terror. Republican partisanship remained a significant predictor of support for Bush across all measures. Fearful whites continued to demonstrate less willingness to retaliate out of fear. 


\begin{tabular}{|c|c|c|c|c|c|c|}
\hline \multicolumn{7}{|c|}{$\begin{array}{l}\text { Table 3.8 | Ethnocentrism and support across race for the war on terrorism in } \\
\text { 2004: Backing the president }\end{array}$} \\
\hline & \multicolumn{2}{|c|}{ General performance } & \multicolumn{2}{|c|}{ War on Terror } & \multicolumn{2}{|c|}{ War in Iraq } \\
\hline Ethnocentrism & $\begin{array}{c}\text { White } \\
0.52 \\
(0.48) \\
{[0.28]}\end{array}$ & $\begin{array}{c}\text { Black } \\
3.66^{* *} \\
(1.69) \\
{[0.03]}\end{array}$ & $\begin{array}{c}\text { White } \\
0.23 \\
(0.43) \\
{[0.60]}\end{array}$ & $\begin{array}{c}\text { Black } \\
1.24 \\
(1.22) \\
{[0.31]}\end{array}$ & $\begin{array}{c}\text { White } \\
0.10 \\
(0.44) \\
{[0.83]}\end{array}$ & $\begin{array}{l}\text { Black } \\
2.75^{*} \\
(1.54) \\
{[0.07]}\end{array}$ \\
\hline Partisanship & $\begin{array}{c}-3.31 * * * \\
(0.29)\end{array}$ & $\begin{array}{c}-1.66^{* *} \\
(0.82)\end{array}$ & $\begin{array}{c}-2.28 * * * \\
(0.24)\end{array}$ & $\begin{array}{l}-0.49 \\
(0.75)\end{array}$ & $\begin{array}{c}-2.49 * * * \\
(0.25)\end{array}$ & $\begin{array}{c}-3.24^{* * *} \\
(0.95)\end{array}$ \\
\hline Education & $\begin{array}{c}-0.85^{* *} \\
(0.29)\end{array}$ & $\begin{array}{c}0.59 \\
(0.67)\end{array}$ & $\begin{array}{l}-0.23 \\
(0.25)\end{array}$ & $\begin{array}{c}0.42 \\
(0.58)\end{array}$ & $\begin{array}{c}-0.43 \\
(0.27)\end{array}$ & $\begin{array}{c}0.98 \\
(0.70)\end{array}$ \\
\hline Threat & $\begin{array}{c}-0.70 * * * \\
(0.10)\end{array}$ & $\begin{array}{l}-0.04 \\
(0.23)\end{array}$ & $\begin{array}{c}-0.55 * * * \\
(0.09)\end{array}$ & $\begin{array}{c}-0.73 * * * \\
(0.21)\end{array}$ & $\begin{array}{c}-0.74^{* * *} \\
(0.09)\end{array}$ & $\begin{array}{l}-0.31 \\
(0.24)\end{array}$ \\
\hline $\mathbf{N}$ & $\begin{array}{l}\text { Tota } \\
\text { Whit } \\
\text { Blacl }\end{array}$ & $\begin{array}{l}=905 \\
=695 \\
=132\end{array}$ & $\begin{array}{l}\text { Total } \\
\text { Whitc } \\
\text { Black }\end{array}$ & $\begin{array}{l}=926 \\
=713 \\
=134\end{array}$ & $\begin{array}{l}\text { Tota } \\
\text { Whit } \\
\text { Blac }\end{array}$ & $\begin{array}{l}=910 \\
=697 \\
=131\end{array}$ \\
\hline $\begin{array}{l}\text { Entries are ordere } \\
\text { Models also cont } \\
\text { evaluations. } \\
* * * \mathrm{p}<0.01 ; * * \\
\text { Source: } 2004 \text { Am } \\
\end{array}$ & $\begin{array}{l}\text { robit reg } \\
\text { for politi } \\
0.05: * p \\
\text { can Natio }\end{array}$ & $\begin{array}{l}\text { sion coeff } \\
\text { awarenes } \\
0.10 ; \mathrm{p}-\mathrm{v}\end{array}$ & $\begin{array}{l}\text { nts with s } \\
\text { ender, anc } \\
\text { s for ethn }\end{array}$ & $\begin{array}{l}\text { andard err } \\
\text { householc } \\
\text { centrism : }\end{array}$ & $\begin{array}{l}\text { in parenth } \\
\text { d national } \\
\text { in brackets }\end{array}$ & $\begin{array}{l}\text { es below. } \\
\text { onomic }\end{array}$ \\
\hline
\end{tabular}

\section{Ethnocentrism and Support for War in Black and White-2008}

As in all cases, I begin my analysis of ethnocentrism's significance in predicting support across race, by examining the distributions of ethnocentrism based on the $E$ scale. ${ }^{48}$ Based on the stereotype measures, ethnocentrism was much the same in 2008. The mean score on the E-scale for all respondents was 0.05 . The mean score across white respondents was 0.06 and significantly higher than the mean score for blacks $(0.00)$. Table 3.9 describes the distribution of ethnocentrism across race, while Figures 5 and 6 provide graphical views of distributions of white and black ethnocentrism. I apply this initial description of the distribution of ethnocentrism across race to analyze support for war. Again, models control for partisanship ${ }^{49}$, education ${ }^{50}$, perception of threat ${ }^{51}$, gender, political awareness $^{52}$, and in evaluations of the president, household ${ }^{53}$ and national $^{54}$ economic evaluations. 


\begin{tabular}{|c|c|c|c|}
\hline \multicolumn{4}{|c|}{ Table 3.9 | Ethnocentrism in 2008} \\
\hline & All Groups & Whites & Blacks \\
\hline Mean & 0.05 & 0.06 & 0.00 \\
\hline St. Dev & 0.14 & 0.13 & 0.15 \\
\hline Range & $(-0.54,0.79)$ & $(-0.54,0.71)$ & $(-0.47,0.79)$ \\
\hline $\mathbf{N}$ & 1842 & 987 & 469 \\
\hline
\end{tabular}

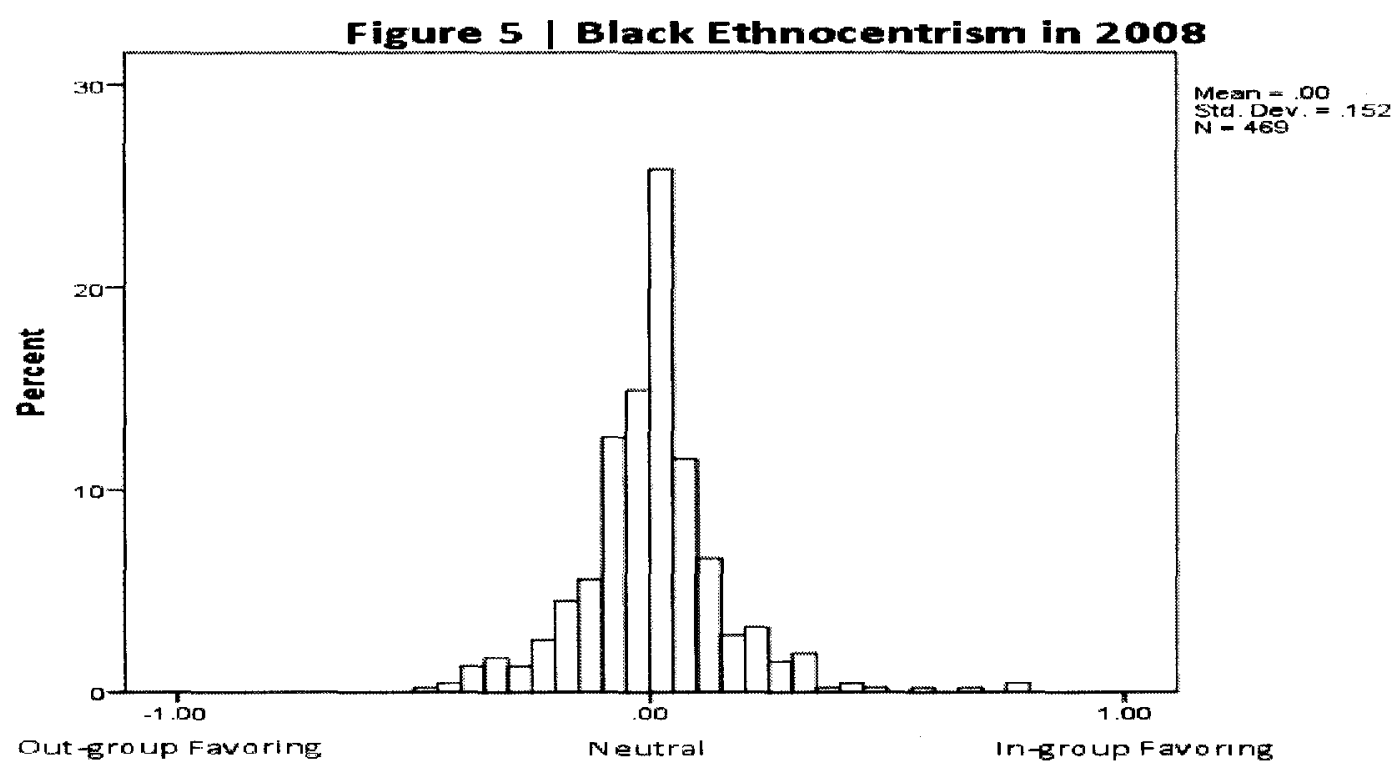

Figure 6 | White Ethnocentrism in 2008

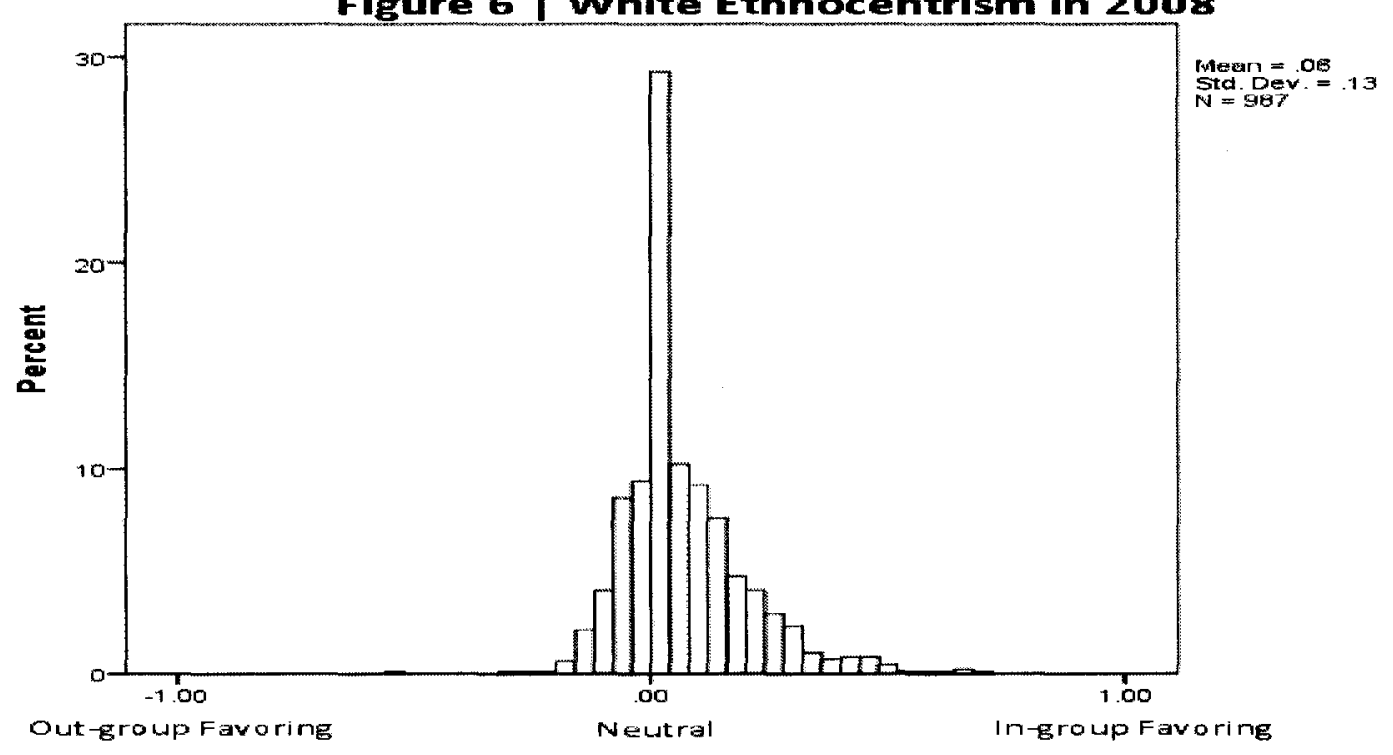


Support for Protecting the Homeland in Black and White-2008

In the 2008 analysis of support for spending to protect the homeland (Table 3.10), ethnocentrism is found to be a significant predictor of American support for increased spending on the war on terror ${ }^{55}$. It is also highly significant in predicting support for spending across white respondents. These are the only cases where ethnocentrism bears significance on spending support, across all races. Americans were calling for troop withdrawals from Iraq and refocus in Afghanistan. Many saw the occupation in Iraq as a waste of time and money, thus many were unlikely to support increased defense spending ${ }^{56}$. Likewise, increased spending was supported by a mere $22 \%$ of respondentsplunging $33 \%$ from 2004 . Americans also felt less threatened at home in 2008 , as many Taliban and al-Qaeda fighters had been driven into hiding by American forces. Only 53\% of respondents supported increased border control spending ${ }^{57}$-down 13\% from 2004. With these things considered, Americans wanted "our" troops to get "them"--those responsible for terrorist attacks in our homeland. Expectedly, ethnocentrism is still a significant predictor of support for increased spending on the war on terror. White Republicans were still significantly supportive of the war on terror and increased border control, but the effect of threat had largely disappeared across the board among white respondents in 2008 . 


\begin{tabular}{|c|c|c|c|c|c|c|}
\hline \multicolumn{7}{|c|}{$\begin{array}{l}\text { Table 3.10 | Ethnocentrism and support across race for the war on } \\
\text { terrorism in 2008: Protecting the homeland }\end{array}$} \\
\hline & \multicolumn{2}{|c|}{ War on Terror } & \multicolumn{2}{|c|}{ Border Control } & \multicolumn{2}{|c|}{ National Defense } \\
\hline Ethnocentrism & $\begin{array}{c}\text { White } \\
1.46^{* * *} \\
(0.48) \\
{[0.00]}\end{array}$ & $\begin{array}{c}\text { Black } \\
1.27 \\
(0.83) \\
{[0.13]}\end{array}$ & $\begin{array}{c}\text { White } \\
0.47 \\
(0.47) \\
{[0.31]}\end{array}$ & $\begin{array}{c}\text { Black } \\
-0.46 \\
(0.78) \\
{[0.55]}\end{array}$ & $\begin{array}{l}\text { White } \\
-1.01 \\
(0.70) \\
{[0.15]}\end{array}$ & $\begin{array}{l}\text { Black } \\
1.58 \\
(0.97) \\
{[0.10]}\end{array}$ \\
\hline Partisanship & $\begin{array}{l}0.39^{*} \\
(0.21)\end{array}$ & $\begin{array}{l}-0.54 \\
(0.42)\end{array}$ & $\begin{array}{c}0.69 * * * \\
(0.21)\end{array}$ & $\begin{array}{c}-0.84^{* *} \\
(0.43)\end{array}$ & $\begin{array}{c}-1.59^{* * *} \\
(0.30)\end{array}$ & $\begin{array}{c}0.05 \\
(0.58)\end{array}$ \\
\hline Education & $\begin{array}{c}-0.65 \\
(0.46)\end{array}$ & $\begin{array}{l}-0.13 \\
(0.78)\end{array}$ & $\begin{array}{c}0.08 \\
(0.46)\end{array}$ & $\begin{array}{c}0.03 \\
(0.80)\end{array}$ & $\begin{array}{l}-1.13^{*} \\
(0.65)\end{array}$ & $\begin{array}{c}-2.29 * * \\
(1.05)\end{array}$ \\
\hline Threat & $\begin{array}{c}0.04 \\
(0.19)\end{array}$ & $\begin{array}{c}0.20 \\
(0.31)\end{array}$ & $\begin{array}{c}-0.02 \\
(0.19)\end{array}$ & $\begin{array}{c}0.35 \\
(0.31)\end{array}$ & $\begin{array}{l}0.40^{*} \\
(0.27)\end{array}$ & $\begin{array}{c}0.30 \\
(0.40)\end{array}$ \\
\hline $\mathbf{N}$ & \multicolumn{2}{|c|}{$\begin{aligned} \text { Total } & =776 \\
\text { White } & =488 \\
\text { Black } & =142\end{aligned}$} & \multicolumn{2}{|c|}{$\begin{aligned} \text { Total } & =777 \\
\text { White } & =487 \\
\text { Black } & =143\end{aligned}$} & \multicolumn{2}{|c|}{$\begin{aligned} \text { Total } & =401 \\
\text { White } & =251 \\
\text { Black } & =72\end{aligned}$} \\
\hline $\begin{array}{l}\text { Entries are order } \\
\text { below. Models al } \\
{ }^{* * *} \mathrm{p}<0.01 ;{ }^{* *} \\
\text { Source: } 2008 \mathrm{Am}\end{array}$ & $\begin{array}{l}\text { obit reg } \\
\text { ntrol f } \\
.05 ; p\end{array}$ & $\begin{array}{l}\text { Ssion } \\
\text { politic } \\
.10 ; p\end{array}$ & $\begin{array}{l}\text { cients } \\
\text { areness } \\
\text { es for } \mathrm{e}\end{array}$ & $\begin{array}{l}\text { stands } \\
\text { d gend } \\
\text { ocentri }\end{array}$ & $\begin{array}{l}\text { ors in } \\
\text { in bra }\end{array}$ & entheses \\
\hline
\end{tabular}

Support for Going to War in Black and White-2008

In 2008 , ethnocentrism is found to be a significant predictor for approval of war in Iraq ${ }^{58}$ (Table 3.11) across all respondents. Only $28 \%$ of all respondents approved of the war in Iraq. Only $38 \%$ of whites approved of the war, and surprisingly, a remarkably miniscule $5 \%$ of black respondents approved. Given the low approval of the war, this significance is attributable to the most ethnocentric cases comprising nearly all of the approval. Ethnocentrism was insignificant in predicting approval of the war in Afghanistan $^{59}$. Disapproval of the war in Afghanistan was much the same as disapproval of the Iraq war across respondents in the analysis. Approval fell from $72 \%$ in 2004 to $26 \%$ in 2008 across all respondents, from $79 \%$ in 2004 to $34 \%$ in 2008 across white respondents, and, astoundingly, from $42 \%$ in 2004 to $8 \%$ in 2008 across black respondents. The 2008 regression analysis reveals that ethnocentrism and perception of 
threat are insignificant in predicting approval, across race, for the wars in Afghanistan and Iraq. However, white Republicans remained supportive of the wars.

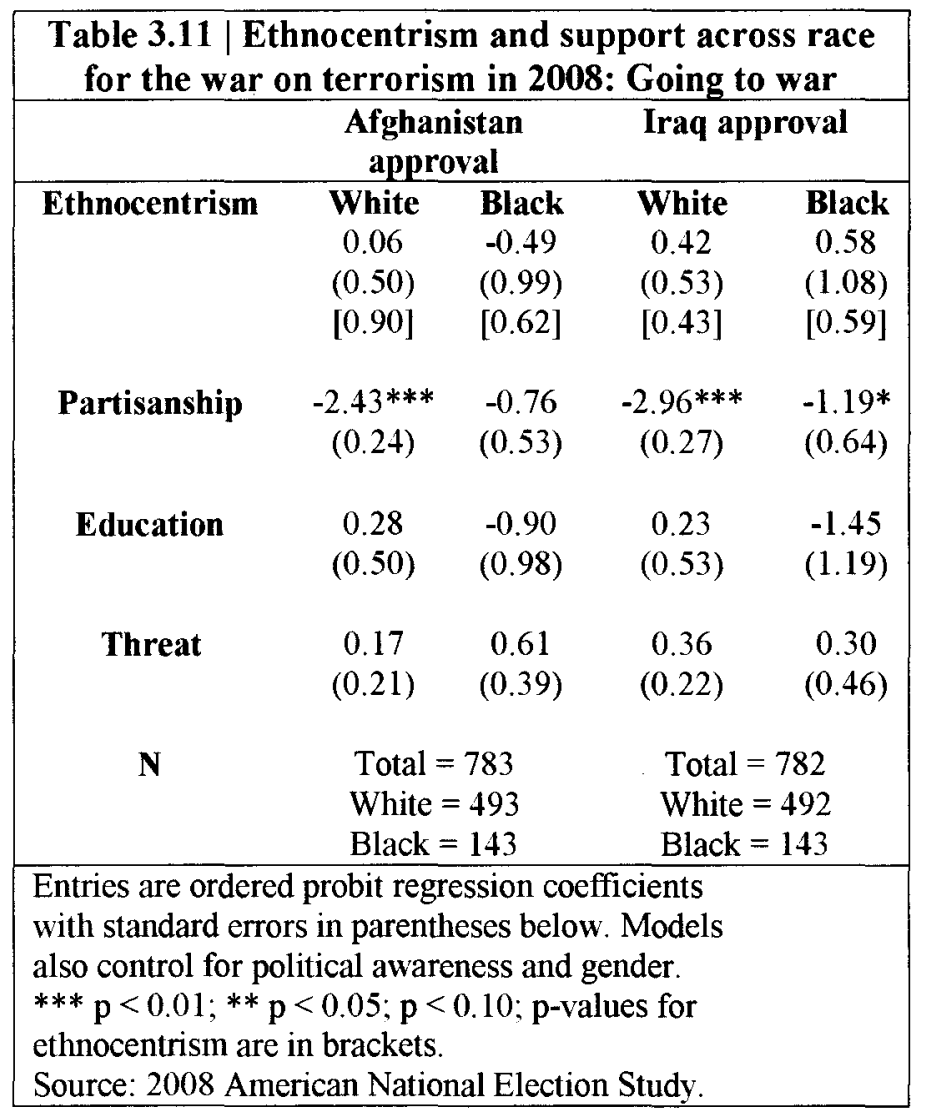

Support for the President in Black and White-2008

In my 2008 analysis of support for the president, a variable measuring support for the president's handling of the war in Iraq ${ }^{60}$ is included. A measure of the president's performance in handling the war on terror was not available. At any rate, this portion of the 2008 analysis (Table 3.12; full table in Appendix I) reaffirms the trends observed regarding ethnocentrism's declining significance in predicting support for spending and predicting approval for the wars. The public had lost interest in the wars, questioned the president's leadership and approach, and demanded new strategy. These considerations began to replace the ethnocentric thinking that garnered support for the wars and support 
for the president. By 2008, across all respondents, only $27 \%$ approved of Bush's general performance $^{61}$, down from $53 \%$ in 2004 . Only $32 \%$ approved of his handling of the war in Iraq, including $36 \%$ of white respondents and $5 \%$ of black respondents approved of Bush, generally. Likewise, ethnocentrism is insignificant in predicting approval of the president on either measure across either race. White Republicans remained significantly supportive of the president.

\begin{tabular}{|c|c|c|c|c|}
\hline \multicolumn{5}{|c|}{$\begin{array}{l}\text { Table 3.12| Ethnocentrism and support across race for } t \\
\text { 2008: Backing the president } \\
\text { General performance }\end{array}$} \\
\hline Ethnocentrism & $\begin{array}{c}\text { White } \\
0.39 \\
(0.66) \\
{[0.56]}\end{array}$ & $\begin{array}{c}\text { Black } \\
-2.31 \\
(2.09) \\
{[0.27]}\end{array}$ & $\begin{array}{c}\text { White } \\
0.02 \\
(0.55) \\
{[0.98]}\end{array}$ & $\begin{array}{l}\text { Black } \\
-1.26 \\
(0.79) \\
{[0.11]}\end{array}$ \\
\hline Partisanship & $\begin{array}{c}-3.40 * * * \\
(0.37)\end{array}$ & $\begin{array}{c}0.05 \\
(0.95)\end{array}$ & $\begin{array}{c}-2.31 * * \\
(0.27)\end{array}$ & $\begin{array}{c}-0.56 \\
(0.41)\end{array}$ \\
\hline Education & $\begin{array}{l}1.61^{* *} \\
(0.66)\end{array}$ & $\begin{array}{c}1.35 \\
(1.54)\end{array}$ & $\begin{array}{l}-0.01 \\
(0.55)\end{array}$ & $\begin{array}{c}-0.51^{*} \\
(0.79)\end{array}$ \\
\hline Threat & $\begin{array}{c}-0.02 * * * \\
(0.27)\end{array}$ & $\begin{array}{c}-0.72 \\
(0.72)\end{array}$ & $\begin{array}{c}0.28 \\
(0.23)\end{array}$ & $\begin{array}{c}0.38 \\
(0.30)\end{array}$ \\
\hline $\mathbf{N}$ & \multicolumn{2}{|c|}{$\begin{aligned} \text { Total } & =765 \\
\text { White } & =479 \\
\text { Black } & =141\end{aligned}$} & \multicolumn{2}{|c|}{$\begin{aligned} \text { Total } & =773 \\
\text { White } & =486 \\
\text { Black } & =142\end{aligned}$} \\
\hline \multicolumn{5}{|c|}{ 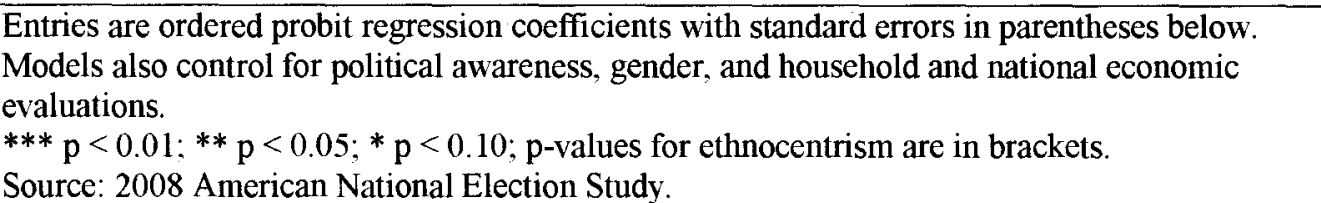 } \\
\hline
\end{tabular}

\section{Conclusion}

In this analysis of ethnocentrism's significance in predicting support for war, I started with Kinder's and Kam's (2009) models and focused on differences across race over time. I hypothesized that ethnocentrism across white individuals would be more significant in predicting support for war than ethnocentrism across black individuals. Not only are white ethnocentrism and whites' perception of threat more significant in 
predicting support, but it is impressively and consistently more significant. The findings reinforce proceeding to test my hypotheses that ethnocentric frames activate ethnocentrism and fear, thereby generating support for war across white individuals.

Auxiliary to the forthcoming main contributions, through this analysis I provide a better way to understand the effects of ethnocentrism on support for war. I suggest that the framework underlying Down's (1972) issue-attention cycle is an appropriate way to understand ethnocentrism and war. I demonstrate that ethnocentrism and fear are indeed powerful in generating support for war at its onset, and are particularly powerful across whites. Still, as wars endure, costs accrue, death tolls grow, strategy is questioned, and so forth, interest diminishes accordingly. I suggest that these considerations supplant ethnocentrism and fear in the way the American public (particularly white Americans) think(s) about war. Largely the desired arena for refocused strategy, ethnocentrism is a significant predictor of support for increased spending on the war on terror in 2002, 2004, and 2008-as is white ethnocentrism in all years. Ethnocentrism is significant in predicting support for increased border control spending, particularly across whites, in 2002 and 2004, but becomes insignificant in 2008. Across all respondents and white respondents, ethnocentrism is significant in predicting support for increased spending on the national defense in 2002, but is insignificant in 2004. Across all respondents, ethnocentrism is significant in predicting support for military action in Iraq in 2002. It is not a significant predictor in 2004 , but becomes significant across the small number of ethnocentric respondents still in approval in 2008. Finally, ethnocentrism is significant in predicting approval for the president's handling of $9 / 11$ and the war on terror in 2002 , but ethnocentrism is insignificant in predicting support for the war in 2004. 
Focusing on these key observations, I reaffirm Kinder's and Kam's assertions that ethnocentrism depends in large part on attention for activation. I demonstrate just how significant ethnocentrism is in garnering support at the onset of conflict. I confirm that whites are indeed more ethnocentric than blacks and that ethnocentrism is more significant in predicting white support for war at its onset. These findings set up my framing experiment perfectly. Tensions with Iran are already receiving high levels of attention and as I demonstrated previously, those tensions are being framed. By presenting a fictitious report, claiming that Iran has in fact developed nuclear weapons, I expected to create the sort of "alarmed discovery and euphoric enthusiasm" and fear theorized by Downs (1972: 39). In presenting respondents with an ethnocentrically framed account, I hypothesized that ethnocentric frames would activate ethnocentrism and fear across white individuals, and generate support for war across white individuals.

As I demonstrate shortly, accepting these two hypotheses is significant for two major reasons. The first is that understanding ethnocentrism and ethnocentric frames as a source of generating support for conflict abroad is substantial unto itself, given all that war entails. Ethnocentrism has been demonstrated to generate support for war and I have provided historical and concurrent content analyses that prove how the media employ ethnocentric frames. In the coming chapter, I demonstrate how these frames are effective in activating ethnocentrism and fear across whites in my sample group, thereby generating support for war. I effectively demonstrate how the media can encourage white Americans' support in a policy arena that has serious consequences on several levels, when considering loss of life, federal expenditure, and foreign relations. 
Even more significant, I have demonstrated that ethnocentrism across whites is a significant predictor of support for war, particularly at its onset. I will demonstrate in the coming chapter that ethnocentric frames are effective in activating ethnocentrism and fear, and generating support for initiating war across white individuals. This is significant when considering the demographic makeup of American political participation. If whites in the representative national electorate react to ethnocentric frames as they do in my sample, then I am describing how frames influence war support across a group that comprised $76.3 \%$ of the previous presidential electorate (Lopez and Taylor 2009). 


\section{CHAPTER IV \\ FRAMING EXPERIMENT}

\section{Hypotheses}

As explained previously, my hypotheses come from the assumptions of several theoretical frameworks: elites frame the media in persuasive or politically advantageous ways; empirical and theoretical findings demonstrate that blacks are less likely to be ethnocentric than whites; ethnocentrism is a significant predictor of support for war, particularly across white individuals; and ethnocentrism is most significant in predicting war at its onset. I suspected that elites frame stories surrounding conflict in ethnocentric terms and demonstrated evidence of such in the previous content analysis. My hypotheses are that ethnocentric frames are more likely than non-framed stories to activate ethnocentrism and fear across white participants, and that the effects of ethnocentrism and fear will be significant in predicting support for war across white individuals.

$\mathrm{H}_{1}$ : The effects of ethnocentric frames will be significant in activating ethnocentrism and fear across white respondents.

$\mathrm{H}_{2}$ : The effects of the activated ethnocentrism and fear will be significant in predicting support for going to war with Iran, across white respondents.

\section{Participants}

In order to obtain a diverse sample group for the experiment, I asked professors from six University of Louisville undergraduate political science courses to encourage 
participation in the experiment, while also conducting an open recruitment of all students at the University of Louisville (a diverse urban research university) and the downtown Louisville campus of Jefferson Community College ${ }^{62}$ Approximately half of the students were drawn from the political science courses, while the remainder was recruited face-toface at various random locations on both campuses, at different times, over a three-day period. Through this process, black respondents were oversampled so that at least 30 received the framed version and 30 received the unframed version. The recruitment process yielded $\mathrm{N}=194$, including 104 whites and 70 blacks

Participants were told they were being recruited for a graduate public opinion study that was examining attitudes about war. Each participant was given a packet consisting of a cover letter explaining the rights of the participants, a one-page news article about an international report confirming Iran's possession of nuclear weapons, and a questionnaire including measures of support for war, an authoritarianism battery, a news/political attention battery, an ethnocentrism battery, and a variety of demographic questions. Participants were randomly assigned to read either an unframed or an ethnocentrically framed account of the article. In accordance with the Institutional Review Board, all participants were debriefed concerning the fictitious article and the purpose of the study once they completed the experiment.

As is often the case with experiments, my sample of participants is unrepresentative of the American population. While I cannot make generalizable statements based on the student sample, I can make causal statements based on a sample that varies demographically and politically. Compared with the 2008 ANES sample, there are sizably greater proportions of black male respondents and white male respondents in 
the experimental sample. The proportion of white respondents in the experiment sample is comparable to its ANES counterpart. However, the proportion of black respondents is moderately higher in the experiment sample, due to the oversampling discussed above. The two samples are distinct regarding the ideological categories, largely due to a very small proportion in the "moderate" category in the experiment sample. While the experiment sample has more respondents in the extremes, proportionally, the distribution follows the same overall trend seen in the 2008 ANES, with blacks more likely to consider themselves liberal and whites more likely to consider themselves conservative. The experiment sample is starkly different with respect to the distribution of age, compared to the 2008 ANES, as most of the respondents are first-time undergraduate students. The mean ethnocentrism score, based on an e-scale battery in the questionnaire, is lower in the experiment sample across both white participants and black participants. In fact, the mean score on the ethnocentrism scale is higher across black respondents than white respondents. I suspect that this finding may be attributable to an underlying social desirability effect across the predominantly white political science sample group. I discuss this suspicion at length in the discussion of results.

Table 4.1 below presents information about key features of my participants and black and white respondents in the 2008 American National Election Study. 


\begin{tabular}{|c|c|c|c|c|}
\hline \begin{tabular}{|l|l} 
Table 4.1 & Des \\
\end{tabular} & riptive Statist & s: 2008 ANES & and Framing I & speriment \\
\hline & 2008 & NES & Framing & xperiment \\
\hline & Blacks & Whites & Blacks & Whites \\
\hline Males & 231 & 523 & 43 & 56 \\
\hline & $(40 \%)$ & $(44 \%)$ & $(63 \%)$ & $(54 \%)$ \\
\hline Females & 341 & 663 & 26 & 48 \\
\hline & $(60 \%)$ & $(56 \%)$ & $(37 \%)$ & $(46 \%)$ \\
\hline$\%$ Total Sample & $25 \%$ & $51 \%$ & $36 \%$ & $54 \%$ \\
\hline Party & & & & \\
\hline Very Lib. & $\begin{array}{c}28 \\
(9 \%)\end{array}$ & $\begin{array}{c}32 \\
(3 \%)\end{array}$ & $\begin{array}{c}2 \\
(3 \%)\end{array}$ & $\begin{array}{c}4 \\
(4 \%)\end{array}$ \\
\hline Liberal & $\begin{array}{c}47 \\
(15 \%)\end{array}$ & $\begin{array}{c}123 \\
(13 \%)\end{array}$ & $\begin{array}{c}30 \\
(43 \%)\end{array}$ & $\begin{array}{c}22 \\
(22 \%)\end{array}$ \\
\hline Slightly Lib. & $\begin{array}{c}33 \\
(11 \%)\end{array}$ & $\begin{array}{c}103 \\
(11 \%)\end{array}$ & $\begin{array}{c}25 \\
(36 \%)\end{array}$ & $\begin{array}{c}16 \\
(16 \%)\end{array}$ \\
\hline Moderate & $\begin{array}{c}113 \\
(37 \%)\end{array}$ & $\begin{array}{c}250 \\
(27 \%)\end{array}$ & $\begin{array}{c}6 \\
(9 \%)\end{array}$ & $\begin{array}{c}17 \\
(17 \%)\end{array}$ \\
\hline Slightly Con. & $\begin{array}{c}37 \\
(12 \%)\end{array}$ & $\begin{array}{c}152 \\
(16 \%)\end{array}$ & $\begin{array}{c}3 \\
(4 \%)\end{array}$ & $\begin{array}{c}11 \\
(11 \%)\end{array}$ \\
\hline Conservative & $\begin{array}{c}33 \\
(11 \%)\end{array}$ & $\begin{array}{c}225 \\
(24 \%)\end{array}$ & $\begin{array}{c}2 \\
(3 \%)\end{array}$ & $\begin{array}{c}26 \\
(26 \%)\end{array}$ \\
\hline Very Con. & $\begin{array}{c}18 \\
(6 \%)\end{array}$ & $\begin{array}{c}44 \\
(5 \%)\end{array}$ & $\begin{array}{c}2 \\
(3 \%)\end{array}$ & $\begin{array}{c}5 \\
(5 \%)\end{array}$ \\
\hline Age & & & & \\
\hline Mean & 46.08 & 49.25 & 19.96 & 21.25 \\
\hline Median & 46.00 & 49.00 & 19.00 & 20.00 \\
\hline Range & $(18,90)$ & $(17,90)$ & $(18,31)$ & $(17,59)$ \\
\hline Ethnocentrism & & & & \\
\hline Mean & 0.00 & 0.06 & -0.02 & -0.04 \\
\hline St. Dev. & 0.15 & 0.13 & 0.07 & 0.11 \\
\hline Range & $(-0.47,0.76)$ & $(-0.54,0.71)$ & $(-0.20,0.24)$ & $(-0.46,0.11)$ \\
\hline
\end{tabular}

\section{Ethnocentric Frame Construction}

Each participant read either an ethnocentrically framed or unframed news article about a United Nations/International Atomic Energy Agency intelligence report leaking the development and possession of nuclear weapons by Iran. The articles were based on real articles in major American newspapers, with the exception of the statements 
regarding the intelligence report. Those fictional statements in the ethnocentrically framed article are reinforced with frames that follow the examples in the previous content analysis. The main text of the article is laden with repeated use of "Islamic" and "Muslim," accompanied by enemy image building terms such as "rogue," "threat," "fundamentalist," "militant," and so forth. Fabricated statements from a fictional White House correspondent and the President underpin the frames and clearly divide the teams into "us" and "them" through repeated use of those pronouns, as well as "we," "they," "their," and "our." These frames are strategically employed at the front, middle, and end of the article, and the framed account has a title consistent with the article's tone. The two versions of the article are provided in Appendices A and B.

\section{Variables}

\section{Dependent Variable}

My dependent variable, support for conflict, was operationalized by constructing an index from nine items, including variables measuring attitudes about justification/support for the use of military force, attitudes about increasing federal spending on the defense and security, and attitudes about the President seeking authorization to deploy troops and/or force. These items and the full questionnaire appear in Appendix C. On each item, respondents indicated support on a five-point scale, which was recoded to run from low support to high support and then added to create the index.

\section{Frame Dummy Variable}

In order to estimate the effect of the ethnocentric frames on priming ethnocentrism, thereby generating support for conflict, I constructed a dummy variable to 
represent the two news stories the participants read. The variable is coded 0 for the unframed account and 1 for the framed account.

\section{Independent Variables}

The independent variables are ethnocentrism and perception of threat. The ethnocentrism measure is operationalized through responses to a stereotype battery replicated from the aforementioned American National Election Study (ANES) surveys. The $e$-scale is constructed by taking the differences in respondents' assessments of their in-group and the average assessment of other out-groups stereotype questions regarding trustworthiness, industriousness, and intelligence. ${ }^{64}$

Perception of threat was applied as a control variable in previous models, by myself and by Kinder and Kam (2009:79), "on the prediction from realistic group conflict theory that support for waging war on anti-American terrorists should be proportionate to the severity of the threat that such terrorists appear to pose. ${ }^{.65}$ In short, the threat items used in the previous ANES models asked respondents how much they feared another attack as serious as September 11. In my experiment, I more or less present the threatIran possessing nuclear weapons - and drawing upon theoretical reasoning, I hypothesized that fear arising from ethnocentrism guides participants' readiness to support initiating war with Iran. Intolerance and xenophobia, ${ }^{66}$ the generalized fear of others, comprise the out-group hostility component of the ethnocentric (Kinder and Kam 2009: 246, note 4). Following this line of thought, I utilized a series of two-stage regression models that used ethnocentrism and the following list of control variables to predict responses to perception of threat, or fear, and then regressed those predicted responses on support for war. This procedure is detailed further in the model section. 


\section{Control Variables}

The control variables I use are also constructed to replicate the variables used in the previous ANES analyses, following Kinder's and Kam's theoretical framework.

Party measures respondents' party identification on a seven-point scale ${ }^{67}$ News information is an index comprised of three items measuring respondents' attention to the news. ${ }^{68}$ These two items were interacted in the analysis, following Kam's and Kinder's (2007) "on the idea that partisans who are most attuned to the elite debate might exhibit the greatest degree of polarization." ${ }^{69}$

Gender is included following Kam's and Kinder's (2007: 327) suggestion that "women are more reluctant than men over the deployment of violence for political purposes." 70

Age appeared on the questionnaire in a format where respondents "filled in the blank" with their specific age in years and is operationalized as such.

Objectivity is a dummy variable included to control for whether or not participants in the experiment noticed the imbalance of the framed account. ${ }^{71}$ The item in the questionnaire (Appendix C) asked participants whether they thought the news article they read provided an objective account of the UN/IAEA report. ${ }^{72}$

Class measures college class on a six-point scale and is employed as an appropriate substitute for the education control used by Kinder and Kam and in my previous ANES models. ${ }^{73}$ The authors demonstrate that the college experience has a greater effect on the decline of ethnocentrism than total years of education and education outside of college (Kinder and Kam 2009: 65). 
Household Economy is included as a substitute for the household economic evaluation used in the previous ANES models, with respect to the theoretical assumption that economic evaluations are strongly correlated with presidential evaluations (Kinder and Kam 2009: 273, note 10), as well as the theoretical assumption that participants living in less favorable economic conditions are less likely to support spending on conflict abroad. $^{74}$

Religiosity is an index, included to control for the possibility that some respondents would see the war in religious terms, particularly those who are given the frame laden with negative language about Islam or Muslims. ${ }^{75}$

Finally, authoritarianism is an index comprised of responses to a four-question authoritarianism battery, intended to control for the likelihood that authoritarians (who submit to established authority) would be eager to follow national leaders' support for war-perhaps those in the media using ethnocentric frames and enemy image construction tactics. ${ }^{76}$

\section{Models}

As mentioned previously, I utilized a series of two-stage regression models to predict support for war across race. Following the theoretical framework that the outgroup component of ethnocentrism is comprised of general fear and hostility toward strangers, I hypothesized that fear arising from ethnocentrism would be a significant predictor of support for war across white individuals who had their ethnocentrism activated or primed by the reinforcing frames. To test my hypothesis and the effect of fear, I ran four two-stage regression models. 
The first set of models directly tests the hypothesis. I selected cases of white participants who received the ethnocentric frame and then used ordered logistic regression to predict responses on the threat measure using ethnocentrism and the list of control variables. Using ordinary least squares regression, I then regressed those predicted responses of whites receiving the reinforcing frame on the index of support for war. This analysis demonstrated the effect of the frame in activating ethnocentrism across white participants, the effect of ethnocentrism in activating fear, and demonstrated how that perception of threat or fear affected support for war. The equations for these models are expressed as:

(If white, received frame): Predicted perception of threat $=\beta_{0}+\beta_{1}$ Ethnocentrism $+\beta_{2}$ Party $+\beta_{3}$ Information $+\beta_{4}$ Party*Information $+\beta_{5}$ Gender $+\beta_{6}$ Age $+\beta_{7}$ Objectivity + $\beta_{8}$ Class $+\beta_{9}$ HouseEconomy $+\beta_{10}$ Religiosity $+\beta_{11}$ Authoritarianism $\rightarrow$ (If white, received frame): Support for war $=\beta_{0}+\beta_{1}$ Predicted perception of threat

With the second set of models, I selected cases of white participants who received the unframed account of the UN/IAEA report and then followed the same two-stage regression procedure mentioned above. This analysis demonstrated the effect of ethnocentrism on perception of threat and how that fear encouraged support for war across white participants not primed by the reinforcing frame. The equations for these models are expressed as:

(If white, no frame): Predicted perception of threat $=\beta_{0}+\beta_{1}$ Ethnocentrism + $\beta_{2}$ Party $+\beta_{3}$ Information $+\beta_{4}$ Party*Information $+\beta_{5}$ Gender $+\beta_{6}$ Age $+\beta_{7}$ Objectivity + $\beta_{8}$ Class $+\beta_{9}$ HouseEconomy $+\beta_{10}$ Religiosity $+\beta_{11}$ Authoritarianism $\rightarrow$ (If white, no frame): Support for war $=\beta_{0}+\beta_{1}$ Predicted perception of threat 
Using these two sets of regressions, I was able to examine the effect of ethnocentrism on fear and then the effect of fear on support for war, across white participants who received the frame and white participants who received the unframed account.

With the third set of models, I selected cases of black participants who received the ethnocentric frame. Again, I used ordered logistic regression to predict responses on the threat measure using ethnocentrism and the list of control variables. Then, using OLS regression, I regressed those predicted responses of black participants receiving the ethnocentric frame on the index of support for war. This analysis demonstrated the effect of the frame in activating ethnocentrism across black participants, the effect of ethnocentrism in activating fear, and demonstrated how that perception of threat or fear affected support for war. The equations for these models are expressed as:

(If black, received frame): Predicted perception of threat $=\beta_{0}+\beta_{1}$ Ethnocentrism $+\beta_{2}$ Party $+\beta_{3}$ Information $+\beta_{4}$ Party ${ }^{*}$ Information $+\beta_{5}$ Gender $+\beta_{6}$ Age $+\beta_{7}$ Objectivity + $\beta_{8}$ Class $+\beta_{9}$ HouseEconomy $+\beta_{10}$ Religiosity $+\beta_{11}$ Authoritarianism $\rightarrow$ (If black, received frame): Support for war $=\beta_{0}+\beta_{1}$ Predicted perception of threat

Finally, with the fourth set of models, I selected cases of black participants who received the unframed account of the UN/IAEA report. Using ordered logistic regression, I generated predicted responses on the threat measure using ethnocentrism and the list of control variables. Using OLS regression, I regressed those predicted responses of black participants receiving the unframed account on support for war. The equations for these models are expressed as: 
(If black, no frame): Predicted perception of threat $=\beta_{0}+\beta_{1}$ Ethnocentrism + $\beta_{2}$ Party $+\beta_{3}$ Information $+\beta_{4}$ Party $*$ Information $+\beta_{5}$ Gender $+\beta_{6}$ Age $+\beta_{7}$ Objectivity + $\beta_{8}$ Class $+\beta_{9}$ HouseEconomy $+\beta_{10}$ Religiosity $+\beta_{11}$ Authoritarianism $\rightarrow$ (If black, no frame): Support for war $=\beta_{0}+\beta_{1}$ Predicted perception of threat

These final two sets of regressions provided for examination of the effect of ethnocentrism on fear and then the effect of fear on support for war, across black participants who did and did not receive the reinforcing frame. With both black comparison groups in hand, I was also able to make the final comparisons between white and black respondents who received the reinforcing frame, as well as white and black respondents who did not receive the reinforcing frame.

\section{Results}

The findings presented in Table 4.2 demonstrate and lead me to accept the first hypothesis, that whites are more likely to have their ethnocentrism activated by reinforcing frames. As shown in the table below, whites who received the ethnocentric frame were more likely to feel threatened by Iran-they were more likely to fear Muslims. When white participants received the reinforcing frame, ethnocentrism was a highly significant predictor of perception of threat $(p=0.00)$. Supporting this finding, and the hypothesis, was the finding that ethnocentrism across black participants was not activated and was insignificant in predicting perception of threat, regardless of which version of the news story they read.

The results from the experiment also unveiled characteristics of the sample group that led me to believe that social desirability effects and sample bias were affecting the distributions of measures when compared to the ANES studies. According to the table 
below, white Republicans were not statistically significantly likely to feel threatened (or likely to support war), while black Republicans were. Black participants who found the article to be objective were also less likely to feel fearful. In addition, the more authoritarian black participants were, the less likely they were to support war.

However, several observations across the black participant group seemingly correspond with how willing whites are to feel threatened and to form ethnocentric considerations of going to war. Attentive black partisans were unlikely to feel threatened. Finally, as age increased, black respondents were less likely to feel threatened (and less likely to support war). 


\begin{tabular}{|c|c|c|c|c|}
\hline \multicolumn{5}{|c|}{$\begin{array}{l}\text { Table } 4.2 \mid \text { Ethnocentric Frames across Race: } \\
\text { The Activation of Ethnocentrism and Fear }\end{array}$} \\
\hline & \multicolumn{2}{|c|}{$\begin{array}{l}\text { Perceived Threat when } \\
\text { Received Frame }\end{array}$} & \multicolumn{2}{|c|}{$\begin{array}{l}\text { Perceived Threat when No } \\
\text { Frame }\end{array}$} \\
\hline & White & Black & White & Black \\
\hline Ethnocentrism & $\begin{array}{c}12.71^{* * *} \\
(3.77)\end{array}$ & $\begin{array}{c}7.25 \\
(6.59)\end{array}$ & $\begin{array}{l}-3.42 \\
(3.22)\end{array}$ & $\begin{array}{c}2.21 \\
(4.74)\end{array}$ \\
\hline Party & $\begin{array}{l}-0.12 \\
(0.43)\end{array}$ & $\begin{array}{l}1.25^{* *} \\
(0.63)\end{array}$ & $\begin{array}{l}-0.38 \\
(0.34)\end{array}$ & $\begin{array}{c}4.86^{* * *} \\
(1.84)\end{array}$ \\
\hline Attention & $\begin{array}{l}-0.74 \\
(0.97)\end{array}$ & $\begin{array}{c}0.54 \\
(0.74)\end{array}$ & $\begin{array}{l}-0.53 \\
(0.82)\end{array}$ & $\begin{array}{c}2.02 \\
(1.48)\end{array}$ \\
\hline Party*Attention & $\begin{array}{c}0.01 \\
(0.19)\end{array}$ & $\begin{array}{l}-0.51^{*} \\
(0.30)\end{array}$ & $\begin{array}{l}-0.19 \\
(0.19)\end{array}$ & $\begin{array}{c}-1.76^{* *} \\
(0.77)\end{array}$ \\
\hline Female & $\begin{array}{c}0.48 \\
(0.76)\end{array}$ & $\begin{array}{c}0.58 \\
(0.59)\end{array}$ & $\begin{array}{l}1.52^{* *} \\
(0.78)\end{array}$ & $\begin{array}{l}-0.40 \\
(0.99)\end{array}$ \\
\hline Age & $\begin{array}{c}0.07 \\
(0.09)\end{array}$ & $\begin{array}{c}-0.54^{*} \\
0.32\end{array}$ & $\begin{array}{l}-0.02 \\
(0.09)\end{array}$ & $\begin{array}{l}-0.27 \\
(0.19)\end{array}$ \\
\hline Objectivity & $\begin{array}{l}-0.57 \\
(0.74)\end{array}$ & $\begin{array}{c}-1.92 * * \\
(0.84)\end{array}$ & $\begin{aligned}-1.60^{* *} \\
(0.74)\end{aligned}$ & $\begin{array}{l}-2.73^{* * *} \\
1.09\end{array}$ \\
\hline Class & $\begin{array}{c}0.21 \\
(0.29)\end{array}$ & $\begin{array}{c}0.18 \\
(0.67)\end{array}$ & $\begin{array}{l}0.95^{* *} \\
(0.46)\end{array}$ & $\begin{array}{l}-0.24 \\
(0.49)\end{array}$ \\
\hline $\begin{array}{l}\text { Household } \\
\text { Economy }\end{array}$ & $\begin{array}{l}-0.12 \\
(0.46)\end{array}$ & $\begin{array}{c}0.22 \\
(0.63)\end{array}$ & $\begin{array}{l}-0.71 \\
(0.61)\end{array}$ & $\begin{array}{l}-0.61 \\
(0.89)\end{array}$ \\
\hline Religiosity & $\begin{array}{c}0.41 \\
(0.44) \\
\end{array}$ & $\begin{array}{c}-0.03 \\
(0.34)\end{array}$ & $\begin{array}{l}-0.14 \\
(0.36) \\
\end{array}$ & $\begin{array}{c}-0.20 \\
(0.45) \\
\end{array}$ \\
\hline Authoritarianism & $\begin{array}{l}-0.54 \\
(1.49)\end{array}$ & $\begin{array}{l}-2.41^{*} \\
(1.34)\end{array}$ & $\begin{array}{c}1.71 \\
(1.75)\end{array}$ & $\begin{array}{c}-3.57^{* *} \\
(1.72)\end{array}$ \\
\hline $\mathrm{N}$ & 51 & 37 & 53 & 33 \\
\hline Pseudo $\mathrm{R}^{2}$ & 0.25 & 0.16 & 0.27 & 0.23 \\
\hline & & & & \\
\hline
\end{tabular}

With these findings, I proceeded to regress the predicted responses of each of the four groups on support for war, to test my hypothesis that whites who have their ethnocentrism and fear activated by frames are more likely to support war. The results in Table 4.3 lead me to accept the hypothesis. Perception of threat or fear of others, the outgroup component of ethnocentrism, was a significant predictor of support for war across white individuals who had their ethnocentrism activated by reinforcing frames. The fear of Muslims explains nearly $30 \%$ of the variance in support for war across white 
participants who had their ethnocentrism primed and activated by the ethnocentric frame. Predicted responses to perception of threat failed to explain more than $4 \%$ of the variance in support for war across each of the other groups I examined (blacks receiving the frame, whites not receiving the frame, and blacks not receiving the frame). Again, reinforcing the hypothesis is the finding that black participants were not in support of war regardless of which account they read.

\begin{tabular}{|c|c|c|c|c|}
\hline \multicolumn{5}{|c|}{$\begin{array}{l}\text { Table } 4.3 \text { | Ethnocentric Frames across Race: } \\
\text { Ethnocentrism, Fear, and Support for War }\end{array}$} \\
\hline & \multicolumn{2}{|c|}{ Received Frame } & \multicolumn{2}{|c|}{ No Frame } \\
\hline & $\begin{array}{l}\text { White } \\
\text { Support }\end{array}$ & $\begin{array}{c}\text { Black } \\
\text { Support }\end{array}$ & $\begin{array}{l}\text { White } \\
\text { Support }\end{array}$ & $\begin{array}{c}\text { Black } \\
\text { Support }\end{array}$ \\
\hline Predicted Threat & $\begin{array}{c}0.41^{* * *} \\
(0.10)\end{array}$ & $\begin{array}{c}0.19 \\
(0.21)\end{array}$ & $\begin{array}{c}0.25 \\
(0.17)\end{array}$ & $\begin{array}{c}0.21 \\
(0.20)\end{array}$ \\
\hline $\mathrm{N}$ & 51 & 37 & 53 & 33 \\
\hline $\mathrm{R}^{2}$ & 0.29 & 0.02 & 0.04 & 0.03 \\
\hline $\begin{array}{l}\text { Entries are ordinary } \\
\text { parentheses below. } \\
* * * p<0.01 ; * * p<\end{array}$ & uares $r$ & & & \\
\hline
\end{tabular}

The results of this experiment suggest that ethnocentric frames indeed are successful in activating ethnocentrism and fear, which in turn drive support for warparticularly across white Americans. Not only does the experiment find that frames have an effect on ethnocentric whites, but it also demonstrates that frames have no significant effect in activating ethnocentrism or generating support for war across black Americans. I discuss the implications of these findings, drawbacks of the study, and suggestion for further research at length in the following chapter. 


\section{CHAPTER V}

\section{CONCLUSION}

\section{Findings}

In this piece, I demonstrated in Chapter 3 the effects of ethnocentrism across time and race. When examining the effects of ethnocentrism on support in a representative American sample, I established that white respondents are more ethnocentric than black respondents, and that their ethnocentrism is a significant driving force behind war support at the onset of the conflict. I suggested that viewing the effects of ethnocentrism on war support through Downs' issue-attention cycle is perhaps an effective tool in understanding American war support. At the onset, Americans-particularly white Americans - are more likely to see war as "us against them," without considering much else. However, as wars endure and support declines, so too does the effect of ethnocentrism on support. Following Downs' theoretical framework, I suggested that as wars endure, the ethnocentric American begins to have other considerations affect his or her support- such as economic and personal costs, foreign relations implications, and even questions of war strategy. Nevertheless, given ethnocentrism's power in predicting war support at the onset of conflict, these findings made testing the effect of frames on causing Americans to want to initiate a war even more appealing.

Kinder and Kam $(2007 ; 2009)$ asserted that the activation of ethnocentrism is contingent upon media framing and issue attention, and demonstrated ethnocentrism to be significant in generating support for war. With historical and concurrent content analyses 
in hand, providing evidence of the media framing and enemy image construction of Islam, I set out to test my hypotheses that these frames are more likely to affect white Americans and cause white Americans to feel threatened and support war. My experiment and regression analyses allow me to accept these two hypotheses, by demonstrating that ethnocentric frames activate ethnocentrism across white participants, thereby causing them to feel threatened, and making them more likely to support initiating conflict with Iran. Furthermore, I have shown the significance of the impact of ethnocentric framing on whites' attitudes, as black participants were unlikely to support war regardless of reading reinforcing frames.

\section{Contribution}

The significance of these findings is two-fold. First, demonstrating how the media encourages American support for war has serious implications on several levels. In effect, I have demonstrated how major American newspapers can influence support for going to war, a policy arena that has entailed the losses of over 5200 American lives since 2000 (Leland and Oboroceanu 2010). I have demonstrated how the media can influence support for spending on war, which annually accounts for approximately $\$ 700$ billion of the federal budget (Department of Defense 2011), I have demonstrated how the media can influence support for war, which continues to have strong implications on American foreign relations, with respect to its allies, its enemies, international organizations, trade, and security.

Secondly, I have demonstrated that ethnocentrism across white Americans is a significant predictor of support for war, particularly at its onset. In demonstrating the causal link between ethnocentric frames, the activation of ethnocentrism, and support for 
war, I have contributed a significant finding considering the demographic makeup of American political participation. I have effectively shown that ethnocentric frames drive support for war across white participants in my study. If that is applicable to the American population, then I have described how frames influence war support across a demographic group that comprised over three-quarters of the 131 million people who voted in the November 2008 presidential election (Lopez and Taylor 2009). If the American media takes a stance on going to war with Iran before the 2012 presidential election, or any nation for that matter, ethnocentric frames will be used accordingly, and I have effectively described how those ethnocentrically framed stories will reach and influence up to 100 million white voters.

\section{Drawbacks}

As stated previously, the results from my experiment are not generalizable to the American population. The experiment was confined to two college campuses in the city of Louisville, Kentucky, which creates several issues of sample bias. I had a sample that was unrepresentative concerning almost every demographic variable-age, education, religiosity, and political affiliation to name a few. The sample almost exclusively includes adults under the age of twenty-three, all of whom are educated, undergoing the "college experience," and living in or around a historically liberal medium-sized metropolitan city in the "Bible belt." Furthermore, while every possible step toward random sampling was taken, a majority of students had to be drawn from classes in the Department of Political Science at the University of Louisville and black respondents were oversampled through face-to-face recruitment at various locations on the Louisville campus, as well as the downtown Louisville campus of Jefferson Community College. 
Again, selection of these recruitment locations and assignation to the framed/unframed stories were made as random as possible, but the sample is nonetheless unrepresentative and the results are not generalizable.

That being said, the experiment still yielded results across individuals who are expected to be more liberal and more tolerant than the overall American population, given their educational status. I was able to make causal statements about the effects frames have on support for war, across white participants, and I was able to accept my hypotheses. Considering the previously demonstrated power of ethnocentrism in driving support for war across white Americans, and the fact that the framing experiment yielded causal statements about a group of savvy, educated, and liberal college students, the findings of this study are intriguing and certainly merit further research utilizing a representative sample.

\section{Suggestions for Further Research}

The most apparent suggestion for further research is to take this project and framing experiment, address the drawbacks listed above, and produce a body of research that allows for generalizability. One suggestion, which I plan to pursue in my professional research, is to have a national-level survey through which I can administer my framing experiment. The most readily appealing option is to secure grant funding and have a national survey company or organization administer the experiment and questionnaire using a Web-based survey tool, such as Qualtrics. I hypothesize that the results found in my experiment will only strengthen when using national-level data, given the causality established using a non-representative sample of college students. 
In my future research, I will also utilize content analysis software to add substance to my analyses of ethnocentric frames. Future projects will utilize such software to analyze the use of frames over time, in parallel comparisons to the significance of ethnocentrism's effects on support for various policy issues at those times. In using this software, I will also seek to make more defined statements about the composition of ethnocentric frames by juxtaposing them against unframed stories.

Furthermore, future research should take my hypotheses and reproduce them with respect to other dependent variables. Kinder and Kam demonstrated the causal link between ethnocentrism and the likelihood of increased support on range of issues-war, increased immigration regulation, opposition to foreign aid, opposition to gay rights, and opposition to out-group benefitting social welfare. My experiment and research focused on the effects of frames on support for war-an enduring and attention-commanding policy arena-across race. The manner in which war grabs and holds the public attention and dominates the media, made it somewhat the most attractive case in which to study. Further research should examine the effects of ethnocentric frames on other policy issues-immigration, gay rights, foreign aid, social welfare, etc.—and examine those effects across race. In a sense, my experiment demonstrated the effects frames have on Americans' support to fight enemies abroad. Interesting future research will employ my hypotheses in testing the effects frames have on Americans' support against each other. The race component of my analyses will be interesting to analyze on ethnocentrism's effects on domestic policy issues.

Finally, further research may examine the effects of ethnocentrism in the final stage of the issue-attention cycle-the so-called stage of prolonged limbo. For example, it 
would be interesting to examine the effects of ethnocentrism in predicting support for the war on terrorism, when it was thrust back into the media spotlight after the death of Osama bin Laden. As my analysis in Chapter 3 demonstrated, the effect of ethnocentrism on support for American wars abroad had decreased significantly by 2008 , but the country breathed a collective sigh of relief when the world's most wanted man was killed in May 2011. Downs' framework implies that issues must endure to complete the cycle and examining the effects of ethnocentrism on support for the war on terrorism again using the 2012 ANES would be interesting. This proposal may also be limited to war policy, but as I have established, very few issues hold the public's attention over time and bear greater life and economic costs as wars do. Testing the effects of ethnocentrism as it and wars complete the issue-attention cycle would merit an important contribution to understanding ethnocentrism as a consequential predisposition in American public opinion. 


\section{NOTES}

${ }^{1}$ Much like the Caribs of the West Indies referred to themselves, "we alone are people"; the Lapps of Nordic culture and Tunguses of Manchuria called themselves "men"; the Ovambo tribe of Africa named themselves "the wealthy"; the Seri of Lower California are suspicious and hostile to all outsiders, forbidding marriage with outsiders; the Jews divided all humanity into themselves and Gentiles; and the Greeks and Romans called all outsiders "barbarians" (Sumner 1906: 14).

${ }^{2}$ In a complementary review of Adorno and his colleagues, Forbes (1985: 27-28) asserts that no explanation can be provided that to support the notion that attitudes toward Jews arise from distinctive characteristics of the Jewish group, but instead the explanation would have to be framed in terms of the common characteristics of other out-groups-or in ethnocentrism terms.

${ }^{3}$ A subsequent study (Greenberg and Rosenfield 1979) of whites' ethnocentrism and their attributions of blacks, asked participants to rate whites and blacks on several personality traits, including laziness, industriousness, intelligence, and so forth (Neuliep and McCroskey 1997: 387). The measure of ethnocentrism was a score consisting of each participant's total rating for the blacks summed over all the traits, subtracted from the participant's total rating for the whites. In the same fashion, yet another study (Taylor and Jaggi 1974) argues that in-group members have a propensity to make internal attributions for the positive behavior of other in-group members, while making external attributions for their negative behavior (Neuliep and McCroskey 1997: 388).

${ }_{5}^{4}$ See: (Bierly 1985; Murphy and Likert 1983; Ray and Lovejoy 1986; Rubinstein 1996).

${ }^{5}$ Similar results were found in studies of soldiers in the "West German army, Maori children in New Zealand, trade school students in Geneva, undergraduates in New York City, and more" (Kinder and Kam 2009: 20). Authors cite: (Billig and Tajfel 1970; Locksley, Ortiz, and Hepburn 1980; Brewer 1979; Brewer and Kramer 1985; Brown 1986; Messick and Mackie 1989; Hewstone, Rubin, and Willis 2002; Mullen, Brown, and Smith 1992; and Brewer and Brown 1998).

${ }^{6}$ Authors cite Martin et al. (1986).

${ }^{7}$ See: (Alford, Funk, and Hibbing 2005; Bouchard et al. 1990; Eaves and Eysenck 1974; Eaves et al. 1999; Olson, Vernon, and Jang 2001).

${ }^{8} 58.9 \%$ scored above the neutral point in a pooled sample of 1992, 1996, 2000, and 2004 NES respondents.

9 "Good evening. Tonight I can report to the American people and to the world that the United States has conducted an operation that killed Osama bin Laden... The American people did not choose this fight. It came to our shores, and started with the senseless slaughter of our citizens. After nearly 10 years of service, struggle, and sacrifice, we know well the costs of war...Yet as a country, we will never tolerate our security being threatened, nor stand idly by when our people have been killed. We 
will be relentless in defense of our citizens and our friends and allies. We will be true to the values that make us who we are. And on nights like this one, we can say to those families who have lost loved ones to al Qaeda's terror: justice has been done" (Obama 2011).

${ }^{10}$ The 1973 Arab-Israeli war, 1973 Arab oil embargo, 1978-1979 Iranian revolution and ensuing hostage crisis, 9/11 attacks, recent military involvements in Iraq and Afghanistan, and concurrent tension surrounding Iran's nuclear intentions.

${ }^{11}$ The Wall Street Journal, USA Today, The New York Times, Los Angeles Times, San Jose Mercury News, The Washington Post, Daily News (NY), New York Post, Chicago Tribune, Chicago Sun-Times, The Dallas Morning News, Houston Chronicle, The Philadelphia Inquirer/Philadelphia Daily News, The Arizona Republic, The Denver Post.

12 This period was selected for manageability and was selected under the assumption that Americans are more focused on the potential threat of a nuclear Iran with the wars in Afghanistan and Iraq largely complete.

${ }^{13}$ Stereotypes of whites, blacks, Hispanics, and Asians on three traits: lazy to hardworking, unintelligent to intelligent, and not trustworthy to trustworthy: V001574 to v001585. The scale was constructed by summing the differences of in-group ratings and out-group ratings, and then dividing those differences to create a scale between 0 and 1 .

${ }^{14}$ The dependent variables are categorical, so the data are analyzed using ordered probit regression. The response categories do not require equal spacing from each other, as ordered probit estimates a series of cutpoints that estimate the distance between response categories.

${ }^{15}$ Partisanship is measured in 2000 (v000523) with a seven-category variable, recoded to range from 0 (strong Republican) to 1 (strong Democrat).

${ }^{16}$ Education is a seven-category measure recoded to range from 0 (less than nine years of schooling) to 1 (advanced degree).

${ }^{17}$ Perception of threat is measured with v023118 and is recoded to range from 0 (very unlikely) to 1 (very likely).

${ }^{18}$ Political awareness is an additive scale of four information items: v001447, v001450, v001453, and v001456. Scale is recoded to range from 0 to 1 .

${ }^{19}$ Dummy coded 1 for females and 0 for males.

${ }^{20}$ Retrospective household economic evaluations are measured with v023026, recoded to range from 0 (negative evaluation of household economic conditions over the past year) to 1 (positive evaluation)

${ }^{21}$ Retrospective national economic evaluations are measured with v023028, recoded to range from 0 (negative evaluations of national economic conditions over the past year) to 1 (positive evaluation).

${ }^{22}$ Authors cite Kinder (1981); Rosenstone (1983); Alesina, Londregan, and Rosenthal (1992).

${ }^{23}$ Attitudes about war on terror spending are measured with v025111Y

${ }^{24}$ Attitudes about border security spending are measured with v025118X.

${ }^{25}$ Attitudes about defense spending are measured with v025114X.

${ }^{26}$ Attitudes about homeland security spending are measured with v025111X 
${ }^{27}$ Attitudes of Afghanistan "worth it" are measured with v023120.

${ }^{28}$ Attitudes of support for military action in Iraq measured with v023122

${ }^{29}$ Approval of Bush's general performance measured with v023005.

${ }^{30}$ Approval of Bush's handling of the war on terror measured with v023119A

${ }^{31}$ Approval of Bush's handling of 9/11 measured with v023119B

${ }^{32}$ Bush asserted that the Taliban would "hand over the terrorists, or... share in their fate" (Bush 2001). In his 2002 State of the Union address, Bush referred to Iraq as part of a three-member "axis of evil," allied with terrorists and posing "a grave and growing danger" (Bush 2002)

${ }^{33}$ Stereotypes of whites, blacks, Hispanics, and Asians on three traits: lazy to hardworking, unintelligent to intelligent, and not trustworthy to trustworthy: v045222 to v045233.

${ }^{34}$ Partisanship is measured with v043116, recoded to range from 0 (strong Republican) to 1 (strong Democrat).

${ }^{35}$ Education is measured with V043254, recoded to range from 0 (less than 9 years of schooling) to 1 (advanced degree).

${ }^{36}$ Perception of threat is measured with v043135 and is recoded to range from 0 (very unlikely) to 1 (very likely).

${ }^{37}$ Political awareness is an additive scale of four information items: v045162a, v045163a, v045164a, v045165a. Scale is coded to run from 0 to 1 .

${ }^{38}$ Retrospective household economic evaluations are measured with v043062, recoded to range from 0 (negative evaluation of household economic conditions over the past year) to 1 (positive evaluation).

${ }^{39}$ Retrospective national economic evaluations are measured with v043098, recoded to range from 0 (negative evaluations of national economic conditions over the past year) to 1 (positive evaluation).

${ }^{40}$ Attitudes about war on terror spending are measured with v043174

${ }^{41}$ Attitudes about border security spending are measured with v043173.

${ }^{42}$ Attitudes about national defense spending are measured with v043142.

${ }^{43}$ Attitudes about Iraq being worth it are measured with v043134.

${ }^{44}$ Attitudes about Afghanistan being worth it are measured with v043131.

${ }^{45}$ Attitudes about Bush's handling of the war on terror

${ }^{46}$ Attitudes about Bush's general performance are measured with v043024.

${ }^{47}$ Attitudes about Bush's handling of the war in Iraq are measured with v043132.

${ }^{48}$ The stereotype measures were found in the pre-election and post-election interviews and were combined to create a reliable measure. The E-scale is constructed using preelection variables V083207a-v083208d and post-election variables v085174av085175d.

${ }^{49}$ Partisanship is measured with v083069, recoded to range from 0 (strong Republican) to 1 (strong Democrat).

${ }^{50}$ Education is measured with v083217, recoded to range from 0 ( 1 year or less of schooling) to 1 (17 years of schooling)

${ }^{51}$ Perception of threat is measured with v085217 and is recoded to range from 0 (very unlikely) to 1 (very likely). 
${ }^{52}$ Political awareness is an additive scale of three institutional items: v085119, v085066, and v085067. Scale is coded to run from 0 (none correct) to 1 (all correct).

${ }^{53}$ Assessment of household economic evaluations is measured with v083057x, recoded to range from 0 (negative evaluation of household economic conditions) to 1 (positive evaluation).

${ }^{54}$ Assessment of national economic evaluations is an additive index of attitudes about the nation's economy, the unemployment rate, and the inflation rate, measured with $\mathrm{v} 083083 \mathrm{x}, \mathrm{v} 083087 \mathrm{x}$, and $\mathrm{v} 083089 \mathrm{x}$. Scale is recoded to range from 0 (negative evaluations of national economic conditions over the past year) to 1 (positive evaluation).

${ }^{55}$ Attitudes about war on terror spending are measured with v083150.

${ }^{56}$ Attitudes about defense spending are measured with v083115.

${ }^{57}$ Attitudes about border spending are measured with v083149.

${ }^{58}$ Attitudes about Iraq approval are measured with v085210.

${ }^{59}$ Attitudes about Afghanistan approval are measured with v085209.

${ }^{60}$ Attitudes about Bush's handling of the war in Iraq are measured with v083033.

${ }^{61}$ Attitudes about Bush's general performance are measured with v083028.

${ }^{62}$ Respondent recruitment, experiment design, and consent protocols were approved by the University of Louisville Institutional Review Board (IRB) and the IRB Human Subjects Protection Program on March 5, 2012.

${ }^{63}$ Strongly Disagree, Disagree, Neither Agree or Disagree, Agree, Strongly Agree. $(\alpha=$ 0.94).

${ }^{64}$ Respondents rated groups on a seven-point scale, from 1 (most favorable rating) to 7 (least favorable rating) and the variable was recoded to run from least favorable (least ethnocentric to most favorable (most ethnocentric).

${ }^{65}$ Authors cite Blumer (1958); Coser (1956); Sherif and Sherif [1953] (1966); and Sumner [1906] (2002).

${ }^{66}$ Authors cite Donald Campbell (1947), who defined xenophobia as a generalized fear and hatred toward strangers.

${ }^{67}$ Coded to run from Strong Democrat to Strong Republican. Responses for "other" (8) and "apolitical" (9) were recoded into missing data.

${ }^{68}$ The three questions asked participants to provide responses to how many days in the past week they read a newspaper, watched national news on TV, and/or read the news online. $(\alpha=0.61)$.

${ }^{69}$ Authors cite Zaller (1992),

${ }^{70}$ Authors cite Conover and Sapiro (1993) and Shapiro and Mahajan (1986).

${ }^{71}$ Coded 1 for receiving the frame; 0 for receiving the unframed account.

${ }^{72}$ The framing manipulation was largely unnoticed, as participants who read the framed articles were most likely to think the account was objective (62\%).

${ }^{73}$ The item is more appropriate as all respondents are college students. The six response categories are 1) freshman, 2) sophomore, 3) junior, 4) senior, 5) graduate student, and 6) doctoral student.

${ }^{74}$ The item in the questionnaire asked participants to evaluate the home they grew up in as "well off financially, somewhere in the middle, or poor." The question was 
formatted in this way, as my sample is comprised of college students, the majority of which likely still live with their parents or are just living on their own for the first time.

${ }^{75}$ Religiosity is comprised of two five-point items that measure religious attendance and religious guidance, recoded to run from low religiosity to high religiosity.

${ }^{76}$ The questions ask about the values most important for parents to emphasize when raising their children, with each posing a choice between the authority of parents and the autonomy of children. The authoritarian prefers respect for elders to independence, obedience to self-reliance, good manners to curiosity, and good behavior to consideration of others. The former in each comparison is coded 1 for the authoritarian response, while other choices are coded 0 . The four dummy variables are added to make the authoritarianism index. $(\alpha=0.61)$. 


\section{REFERENCES}

911Review. 2003. "SCATANA." http://911 review.org/Sept11Wiki/Scatana.shtml. Accessed: January 27, 2012.

Adorno, T.W., Else Frenkel-Brunswik, Daniel J. Levinson, and R. Nevitt Sanford. 1950. The Authoritarian Personality. New York: Harper and Row.

Alesina, Alberto, John Londregan, and Howard Rosenthal. 1993. "A model of the political economy of the United States." American Political Science Review 87 (1): 12-33.

Alford, John, Carolyn Funk, and John R. Hibbing. 2005. "Are political orientations genetically transmitted?" American Political Science Review. 87 (1): 12-33.

Audit Bureau of Circulations. 2011. US Newspaper - Search Results. http://abcas3 accessabc.com/ecirc/newstitlesearchus.asp. Accessed January 29, 2012.

Bierly, M. M. 1985. "Prejudice toward contemporary outgroups as a generalized attitude." Journal of Applied Social Psychology 15: 255-260.

Billig, Michael, and Henri Tajfel. 1973. "Social categorization and similarity in intergroup behavior." European Journal of Social Psychology 3: 27-52.

Blumer, Herbert. 1958. "Race prejudice as a sense of group position." Pacific Sociological Review 1: 3-7. 
Bouchard, T. J., D.T. Lykken, M. McGue, N. L. Segal, and A. Tellegen. 1990. "Sources of human psychological differences. The Minnesota study of twins reared apart." Science 223-28.

Brewer, Marilynn B. 1979. "Intergroup bias in a minimal intergroup situation: A cognitive motivational analysis. Psychological Bulletin 86: 307-24.

Brewer, Marilynn B. 1999. "The psychology of prejudice: Ingroup love or outgroup hate? Journal of Social Issues 55 (3): 429-44.

Brewer, Marilynn B. 2007. "The importance of being we: Human nature and intergroup relations. American Psychologist 62 (8): 728-38.

Brewer, Marilynn B., and Rupert J. Brown. 1998. "Intergroup relations.” In $\underline{\text { Handbook of }}$ social psychology, $4^{\text {th }}$ ed., ed. Daniel Gilbert, Susan T. Fiske, and Gardner Lindzey, 554-94. Boston: McGraw-Hill.

Brewer, Marilynn B., and R.M. Kramer. 1985. "The psychology of intergroup attitudes and behavior." Anmual Review of Psychology 36: 219-43.

Brewer, Paul R. 2001. "Value Words and Lizard Brains: Do Citizens Deliberate about Appeals to Their Core Values?" Political Psychology 22 (1): 45-64.

Brewer, Paul. R. and Kimberly Gross. 2005. "Values, Framing, and Citizens' Thoughts about Policy Issues: Effects on Content and Quantity." Political Psychology 26 (6): 929-948.

Brown, Roger. 1986. Social psychology. $2^{\text {nd }}$ ed. New York: Free Press.

Brzezinski, Zbigniew. 1983. Power and principle: Memoirs of the national security adviser, 1977-1981. New York: Farrar, Straus, and Giroux. 
Buchanan, Mark. 2007. "Born prejudiced." New Scientist 193, no. 2595: 40-43. Academic Search Premier, EBSCOhost. Accessed: January 25, 2012.

Burns, Roberts. 2010, February 14. "U.S. seeks to shore up support for tough Iran stance." San Jose Mercury News.

Bush, George W. 2001, September 20. "Address to a Joint Session of Congress and the American People." The White House. http://georgewbushwhitehouse.archives.gov/news/releases/2001/09/20010920-8.html. Accessed: $02 / 20 / 12$.

Bush, George W. 2002, January 29. "President Delivers State of the Union Address." The White House. http://georgewbushwhitehouse archives.gov/news/releases/2002/01/20020129-11.html. Accessed: $02 / 20 / 2012$.

Campbell, Donald T. 1947. "The generality of a social attitude." $\mathrm{PhD}$ diss., University of California, Berkeley.

Campbell, Donald T. 1965. "Variation and selective retention in socio-cultural evolution. In Social change in developing areas, ed. Herbert R. Barringer, George I. Blanksten, and Raymond W. Mack, 19-49. Cambridge, MA: Schenkman.

Campbell, Donald T. 1975. "On the conflicts between biological and social evaluation and between psychology and moral tradition. American Psychologist 30 (12): $1103-$ 26.

Cappella, Joseph N., and Kathleen Hall Jamieson. 1997. Spiral of Cynicism: The Press and the Public Good. New York: Oxford University Press.

Carter, Jimmy. 1982. Keeping faith: Memoirs of a president. New York: Bantam Books. 
Center for Arms Control and Non-Proliferation. 2010. "Growth in U.S. Defense Spending Since 2001."

http://armscontrolcenter.org/policy/securityspending/articles/fy11_growth_since_200 1/. Accessed: 02/22/12.

Chong, Dennis, and James N. Druckman. 2007. "Framing Public Opinion in Competitive Democracies." American Political Science Review 101 (4): 637-655.

Cohen, Richard. 2011, October 18. "Cohen: The irrationality that is Iran." San Jose Mercury News.

Congressional Research Service. 2002. "Report for Congress: The Economic Effects of 9/11: A Retrospective Assessment." United States Congress, Library of Congress. http://www.fas.org/irp/crs/RL31617.pdf. Accessed January 28, 2012.

Conover, Pamela Johnston, and Virginia Sapiro. 1993. "Gender, feminist consciousness, and war." American Journal of Political Science 37 (4): 1079-99.

Coser, Lewis A. 1956. The functions of social conflict. Glencoe, IL: Free Press.

Dallas Morning News. 2010, March 17. “Iran sanctions can't work without enforcement." The Dallas Morning News.

Darwin, Charles. 1871. The descent of man. New York: Appleton.

Department of Defense. 2011. "Funding Highlights." United States Government Printing Office. Budget. http://www.gpoaccess.gov/usbudget/fy 10/pdf/budget/defense.pdf. Accessed: January 28, 2012. 
Department of Homeland Security. 2011. "Secretary Napolitano Releases Report Highlighting DHS Progress Fulfilling 9/11 Commission Recommendations." Homeland Security. http://www.dhs.gov/ynews/releases/20110721-napolitanoreleases-9-11-progress-report.shtm Accessed: January 28, 2012.

DeYoung, Karen, and Scott Wilson. 2012, January 11. "Public ire is one goal of sanctions against Iran, U.S. official says." The Washington Post.

Dorell, Oren. 2011, October 13. "Alleged Iran terror plan shows no fear of U.S., experts say." USA Today.

Downs, Anthony. 1957. An economic theory of democracy. New York: Harper.

Downs, Anthony. 1972. "Up and Down with Ecology—the Issue-Attention Cycle." Public Interest 28: 38-50.

Druckman, James N. 2001 a. "The Implications of Framing Effects for Citizen Competence." Political Behavior 23 (3): 225-256.

Druckman, James N. 2001b. "On the Limits of Framing Effects: Who Can Frame?" Journal of Politics 63 (4): 1041-1066.

Eaves, L. J., and H. Eysenck. 1974. "Genetics and the devlopment of social attitudes. Nature. 249.(5454: 288;289).

Eaves, L. J., Andrew Heath and Nicholas Martin, Hermine Maes, Michael Neale, Kenneth Kendler, Katherine Kirk, and Linda Corey. 1999. Genes, culture: An empirical approach. New York: Academic Press.

Entman, Robert M. 1993. "Framing: Toward Clarification of a Fractured Paradigm." Journal of Communication 43:51-58.

Esposito, John L. 1983. Voices of resurgent Islam. New York: Oxford University Press. 
Forbes, H. D. 1985. "Nationalism, ethnocentrism, and personality." Chicago: University of Chicago Press.

Freedman, P. 1997. "Framing the partial birth abortion debate: A survey experiment." Paper presented at the annual meeting of the Midwest Political Science Association, Chicago.

Gamson, William A., and Andre Modigliani. 1987. "The Changing Culture of Affirmative Action." In Research in Political Sociology, vol. 3, ed. Richard D. Braungart. Greenwich, CT: JAI Press.

Gerges, Fawaz A. "Islam and Muslims in the Mind of America." 2003. Annals of the American Academy of Political and Social Science 588. Islam: Enduring Myths and Changing Realities: 73-89.

Gitlin, Todd. 1980. The Whole World Is Watching: Mass Media in the Making and Unmaking of the New Left. Berkeley: University of California Press.

Gladstone, Rick, and Harvey Morris. 2012, January 10. "Iran Sentences American to Die On Spy Charges." The New York Times.

Glazier, Liz. 2008. "Lost lives remembered during 9/11 ceremony." The Rocket. http://www.theonlinerocket.com/news/lost-lives-remembered-during-9-11-ceremony1.2333384\#.TyJDNvmt0TA Accessed: January 27, 2012.

Greenberg, J. and D. Rosenfield. 1979. "Whites' ethnocentrism and their attributions for the behavior of Blacks: A motivational bias." Journal of Personality 47: 643-657.

Gross, Kimberly, and Lisa D'Ambrosio. 2004. "Framing Emotional Response." Political Psychology 25 (1). 
Hammond, Ross A., and Robert Axelrod. 2006. "The Evolution of Ethnocentrism." Journal of Conflict Resolution 50, no. 6: 1-11.

Hewstone, M., M. Rubin, and H. Willis. 2002. "Intergroup bias." Annual Review of Psychology 53: 575-604.

Kahneman, Daniel, and Amos Tversky. 1984. "Choices, values, and frames." American Psychologist 39: 341-350.

Kahneman, Daniel, and Amos Tversky.1979. "Prospect theory: An analysis of decision under risk." Econometrica 47: 263-291.

Kinder, Donald R. 1981. "Presidents, prosperity, and public opinion." Public Opinion Quarterly 45 (1): 1-21.

Kam, Cindy D., and Donald R. Kinder. "Terror and Ethnocentrism: Foundations of American Support for the War on Terrorism." May 2007. The Journal of Politics 69, no. $2: 332$.

Kinder, Donald R., and Cindy D. Kam. 2009. Us Against Them: Ethnocentric Foundations of American Opinion. Chicago: The University of Chicago Press: 1-61.

Kinder, Donald R., and Lynn M. Sanders (1990). "Mimicking political debate with survey questions: The case of white opinion on affirmative action for blacks." Social Cognition 8: 73-103.

Kinder, Donald R., and Thomas R. Palfrey. 1993. Experimental Foundations of Political Science. University of Michigan Press.

Klapper, Bradley, and Robert Burns. 2012, January 4. "US to Iran: American warships to remain in Gulf." The Philadelphia Inquirer. 
Leland, Anne, and Mari-Jana Oboroceanu. 2010. American War and Military Operations Casualties: Lists and Statistics. United States Congress, Congressional Research Service. http://www.fas. org/sgp/crs/natsec/RL32492.pdf. Accessed: October 17, 2011.

Levinson, Daniel J. 1949. An approach to the theory and measurement of ethnocentric ideology. The Journal of Psychology 28: 19-39.

Lewis, Anthony. 1995. "This is America." New York Times. May 1.

Lloyd, E. A. 2001. "Units and Levels of Selection: An Anatomy of the Units of Selection Debates." In R. S. Singh et al. (eds.), Thinking About Evolution. Cambridge, MA: Cambridge University Press.

Locksley, Anne, Vilma Ortiz, and Christine Hepburn. 1980. "Social categorization and discriminatory behavior: Extinguishing the minimal intergroup discrimination effect." Journal of Personality and Social Psychology 39, no. 5: 773-783. PsycINFO, EBSCOhost. Accessed: January 25, 2012.

Lopez, Mark Hugo, and Paul Taylor. 2009, April 30. "Dissecting the 2008 Electorate: Most Diverse in U.S. History." Pew Research Center. http://pewresearch.org/pubs/1209/racial-ethnic-voters-presidential-election. Accessed $3 / 21 / 12$.

Martin, N. G., L. J. Eaves, A. C. Heath, Rosemary Jardine, Lynn M. Feingold, and H.J. Eysenck. 1986. "Transmission of social attitudes." Proceedings of the National Academy of Sciences. 83 (12): 4364-68.

Mendelberg, T. 2001. The Race Card. Princeton, NJ: Princeton University Press. 
Merskin, Debra. 2004. "The Construction of Arabs as Enemies: Post-September 11 Discourse of George W. Bush.” Mass Communication \& Society 7(2):157-75. Messick, D.M., and D.M. Mackie. 1989. "Intergroup relations." Anmual Review of Psychology 40: 45-81.

Mullen, B., R. Brown, and C. Smith. 1992. "Intergroup bias as a function of salience, relevance, and status: An integration." European Journal of Social Psychology 22: $103-22$

Murphy, G., and R. Likert.1983. Public opinion and the individual. New York: Harper \& Brother.

Nelson, Thomas E., and Donald R. Kinder. 1996. "Issue frames and group-centrism in American public opinion." Journal of Politics 58: 1055-1078.

Nelson, Thomas E., Zoe M Oxley, and Rosalee A. Clawson. 1997. "Toward a Psychology of Framing Effects." Political Behavior 19: 221-246.

Neuliep, James W., and James C. McCroskey. 1997. "The Development of a U.S. and Generalized Ethnocentrism Scale." Communication Research Reports 14, no. 4: 385398.

Norrander, Barbara, and Clyde Wilcox. 2002. Understanding Public Opinion. Washington, D.C.: CQ Press.

Obama, Barack. 2011. "Full text of Obama's speech on bin Laden's death." CBS News. http://www.cbsnews.com/8301-503544_162-20058783-503544.html. Accessed January $28,2012$.

Okasha, S. 2006. Evolution and Levels of Selection. Oxford: Oxford University Press. 
Olson, J.M., P.A. Vernon, and K.L. Jang. 2001. "The heritability of attitudes: A study of twins." Journal of Personality and Social Psychology 80: 845-860.

PBS.org. 2008, July 18. "Timeline: War in Afghanistan." www.pbs.org/now/shows/428/afghanistan-timeline.html. Accessed: 02/20/2012.

Puzzanghera, Jim. 2012, January 9. "U.S. Warns Iran against blocking oil passageway; The American military will quickly respond, the Defense secretary says." The Los Angeles Times.

Ray, J. J., and F. A. Lovejoy. 1986. "The generality of racial prejudice." The Journal of Social Psychology 1-6: 563-564.

Rosenstone, Steven J. 1983. Forecasting presidential elections. New Haven, CT: Yale University Press.

Rubinstein, G. 1996. "Two peoples in one land: A validation study of Altmeyer's right wing authoritarianism scale in the Palestinian and Jewish societies in Israel." Journal of Cross-Cultural Psychology 27: 216-230.

Rushton, J. Philippe. 2005. "Ethnic nationalism, evolutionary psychology, and Genetic Similarity Theory*." Nations and Nationalism 11 (4): 489-507.

Sellers, R.M., M.A. Smith, J.N. Shelton, S.A.J. Rowley, and T.M. Chavous. 1998. "Multidimensional model of racial identity: A reconceptualization of African American racial identity." Personality and Social Psychology Bulletin 2: 18-39.

Shapiro, Robert Y., and Harpreet Mahajan. 1986. "Gender differences in policy preferences: A summary of trends from the 1960s to the 1980s." Public Opinion Quarterly 50 (1): 42-61. 
Sheridan, Mary Beth, and Colum Lynch. 2010, May 3. "Nuclear treaty conference set for a showdown; U.S., Iran compete for allies as dispute over Tehran program grows." The Washington Post.

Sherif, Muzafer, and Carolyn W. Sherif. [1953] 1966. Groups in harmony and tension. New York: Octagon Books.

Simon, Herbert A. 1983. Reason in human affairs. Palo Alto, CA: Stanford University Press.

Slade, Shelly. 1981. "The image of the Arab in America: Analysis of a poll on American attitudes." Middle East Journal 35 (Spring).

Sniderman, Paul M. and Sean M. Theriault. 2004. "The Structure of Political Argument and the Logic of Issue Framing." In Studies in Public Opinion, eds. Willem E. Saris, and Paul M. Sniderman. Princeton: Princeton University Press: 133-165.

Sober, Elliot, and David Sloan Wilson. 1998. Unto others: The evolution and psychology of unselfish behavior. Cambridge, MA: Harvard University Press.

Sumner, William Graham. (1906) 2002. Folkways: A Study of Mores, Manners, Customs, and Morals. Mineola, NY: Dover Publications.

Tajfel, Henri. 1981. Human groups and social categories. Cambridge: Cambridge University Press.

Tajfel, Henri, M. G. Billig, R. P. Bundy, and C. Flament. 1971. "Social Categorization and Intergroup Behavior." European Journal of Social Psychology 1 (2): 149-78.

Tajfel, Henri, and John C. Turner. 1979. "An integrative theory of intergroup conflict. In The social psychology of intergroup relations, ed. William G. Austin and Stephen Worchel, 33-48. Monterey, CA: Brooks/Cole. 
Taylor, D., and V. Jaggi. 1974. "Ethnocentrism and causal attributions in a South Indian context." Journal of Cross-cultural Psychology 5: 162-171.

Tversky, Amos, and Daniel Kahneman. 1974. "Judgment under uncertainty: Heuristics and biases." Science 185:n1124-1131.

Tversky, Amos, and Daniel Kahneman. "The framing of decisions and the psychology of choice." Science 211 (4481) 453-458.

United States Department of Justice. 2010. "Highlights of the USA Patriot Act." Preserving Life and Liberty. http://web.archive.org/web/20100405093733/http://www. justice.gov/archive/11/highlights.htm. Accessed January 28, 2012.

Venkatraman, Amritha. 2006. "Fundamentalism and Its Stereotypes." Medunarodni Problemi/International Problems 59, 1-2: 7-35.

Welker, Kristen. 2011. "Obama decision on Afghanistan troop withdrawal to come soon." First Read on msnbc.com. http://firstread.msnbc.msn.com/_news/2011/06/06/6798666-obama-decision-onafghanistan-troop-withdrawal-to-come-soon. Accessed: January 28, 2012.

Wilson, Edward O. 1978. On human nature Cambridge, MA: Harvard University Press. 


\section{APPENDIX A}

\section{FRAMED ARTICLE}

\section{Rogue Islamic Nation Confirmed to Have Nuclear Weapons}

Washington, DC - Yesterday, a joint United Nations/International Atomic Energy Agency intelligence report was leaked confirming that the Islamic republic of Iran has developed and possesses nuclear weapons. The one-thousand-plus page report confirms American and European beliefs that Tehran has been secretly building nuclear weapons. For years, Iran's Islamic leadership has maintained that its goal in developing a nuclear program is to generate electricity without dipping into the oil supply it prefers to sell abroad and to provide fuel for medical reactors.

While the United States and other Western nations have suspected weapons development in the Islamic republic since 2003, a lack of concrete intelligence has subjected the United States to a decade of tense relations, disarmament negotiations, inspections, financial and trade sanctions, and potential embargos on the Islamic nation's goods.

The UN/IAEA report confirms that nuclear weapons are stored in a new nuclear facility, which is surrounded by anti-aircraft guns, and is in a mountainous setting ideal for making bombing campaigns nearly impossible. Top officials in the radical Muslim government have long warned of retaliation and attack resulting from U.S. involvements in the Middle East. With the release of this intelligence, years of attempts at diplomacy will likely cease and armed conflict between the United States and the militant Islamic nation will likely become reality.

White House Correspondent Brad Hambrick reports that, "The President knows Republican presidential hopefuls are talking tough on Iran. He knows the release of the UN/IAEA report will heighten public concern. He will be meeting with top security officials this week to coordinate the best response to their nuclear developments."

In a brief press statement, the President declared, "We have suspected that they have been deliberately misleading the international community for years, regarding their nuclear ambitions. They now pose a great threat to us, as well as our allies abroad, and such rogue behavior will not be tolerated by the United States."

Even as years of deception have now been realized, Russia, China, Britain, France, and European Union foreign policy leaders still call for multilateral talks with 
Iran. With Republican presidential hopefuls calling for action, a stern response from the Obama administration to the Islamic fundamentalist regime seems eminent. 


\section{APPENDIX B}

\section{UNFRAMED ARTICLE}

\section{Report Confirms Iran Has Nuclear Weapons}

Washington, DC - Last week, a joint United Nations/International Atomic Energy Agency intelligence report was leaked confirming that Iran has developed and possesses nuclear weapons. The one-thousand-plus page report confirms American and European beliefs that Tehran has been secretly building nuclear weapons. For years, the Iranian government has maintained that its goal in developing a nuclear program is to generate electricity without dipping into the oil supply it prefers to sell abroad, and to provide fuel for medical reactors.

While the United States and other Western nations have suspected weapons development in Iran since 2003, a lack of concrete intelligence has subjected the United States to a decade of tense relations, disarmament negotiations, inspections, financial and trade sanctions, and potential embargos on Iranian goods.

The UN/IAEA report confirms that nuclear weapons are stored in a new nuclear facility, which is surrounded by anti-aircraft guns, and is in a mountainous setting ideal for making bombing campaigns nearly impossible. Top officials in the Iranian government have long warned of retaliation and attack resulting from U.S. involvements in the Middle East. With the release of this intelligence, years of attempts at diplomacy will likely cease and armed conflict between the United States and the Iranians will likely become reality.

White House Correspondent Brad Hambrick reports that, "The President knows Republican presidential hopefuls are talking tough on Iran. He knows the release of the UN/IAEA report will heighten public concern. He will be meeting with top security officials this week to coordinate the best response to Iran's nuclear developments."

In a brief press statement, the President declared, "The United States has suspected that Iran has been deliberately misleading the international community for years, regarding nuclear ambitions. Iran poses a great threat to the international community, and such behavior will not be tolerated by the United States."

Even as years of deception have now been realized, Russia, China, Britain, France, and European Union foreign policy leaders still call for multilateral talks with Iran. With Republican presidential hopefuls calling for action, a stern response from the Obama administration to Tehran seems eminent. 


\section{APPENDIX C \\ QUESTIONNAIRE}

Please check the box next to the response that comes closest to your own view for the following questions or statements.

1. The United States should take military action against Iran.

- Strongly Agree

Agree

$\square \quad$ Neither Agree or Disagree

$\square$ Disagree

$\square$ Strongly Disagree

2. Military action against Iran is justified now that we know that they have nuclear weapons.

[ $]$ Strongly Agree

$\square$ Agree

- Neither Agree or Disagree

$\square$ Disagree

$\square$ Strongly Disagree

3. The United States should use force to prevent Iran from using nuclear weapons.

[ Strongly Agree

- Agree

$\square$ Neither Agree or Disagree

[ Disagree

- Strongly Disagree 
4. Military action against Iran would be worth the cost.

$\square$ Strongly Agree

$\square$ Agree

$\square$ Neither Agree or Disagree

Disagree

$\square$ Strongly Disagree

5. Federal spending on conflict with Iran should be increased.

Strongly Agree

(1) Agree

$\square$ Neither Agree or Disagree

$\square$ Disagree

$\square$ Strongly Disagree

6. Federal spending on national defense should be increased.

$\square$ Strongly Agree

$\square$ Agree

Neither Agree or Disagree

Disagree

口 Strongly Disagree

7. Federal spending on homeland security should be increased.

1] Strongly Agree

Agree

Neither Agree or Disagree

$\square$ Disagree

$\square$ Strongly Disagree

8. The President should seek authorization to deploy troops to Iran.

Strongly Agree

Agree

Neither Agree or Disagree

Disagree

- Strongly Disagree 
9. The President should seek authorization to use military force against Iran.

Strongly Agree

$\square$ Agree

Neither Agree or Disagree

$\square$ Disagree

$\square$ Strongly Disagree

Now I would like to ask you a few questions about your political beliefs and your attention to the news. Please choose the answer that comes closest to your own view.

10. How many days in the PAST WEEK did you read a daily newspaper?

None

One day

$\square$ Two days

$\square \quad$ Three days

$\square$ Four days

$\square$ Five days

Six days

$\square$ Every day

11. How many days in the PAST WEEK did you watch NATIONAL news on TV?

None

$\square$ One day

$\square$ Two days

$\square \quad$ Three days

$\square$ Four days

$\square$ Five days

$\square$ Six days

$\square$ Everyday 
12. How many days in the PAST WEEK did you read news ONLINE?

$\square$ None

$\square$ One day

Two days

Three days

Four days

Five days

$\square$ Six days

$\square$ Every day

13. How would you describe your party identification? Choose the label that best describes how you think of yourself:

Strong Democrat

口 Weak Democrat

$\square$ Independent leaning toward Democrat

$\square$ Independent; I don't identify with a political party

$\square$ Independent leaning toward Republican

Weak Republican

- Strong Republican

I Identify with a party other than Democrat or Republican

I I am apolitical

14. Do you think the news article you read provided an objective account of the UN/IAEA report?

Yes

- No

15. How likely do you think it is that the U.S. will suffer an attack from Iran sometime in the next 12 months?

Very likely

Somewhat likely

Don't know

$\square$ Somewhat unlikely

$\square$ Very unlikely 
16. How would you describe your political ideology? Choose the point on the scale that best describes your political views:
Very Conservative
Conservative
- Slightly Conservative
Middle of the Road
Slightly Liberal
Liberal
Very Liberal

17. Some people seem to follow what is going on in government and public affairs most of the time, whether there is an election going on or not. Others are not that interested. Would you say you follow what is going on in government and public affairs most of the time, some of the time, only now and then, hardly at all, or never?

$\square$ Most of the time

Some of the time

$\square$ Only now and then

- Hardly at all

$\square$ Never

Now I would like to ask you some questions about what you think it is important for a child to have. Please choose the answer that comes closest to your own view.

18. Which one of these do you think is more important for a child to have: independence or respect for elders?

$\square$ Independence

$\square$ Respect for elders

Both

$\square$ Neither

$\square$ Don't know

19. Which one of these do you think is more important for a child to have: obedience or self-reliance?
a. Obedience
b. Self-reliance
c. Both
d. Neither
e. Don't know 
20. Which one of these do you think is more important for a child to have: curiosity or good manners?
a. Curiosity
b. Good Manners
c. Both
d. Neither
e. Don't know

21. Which one of these do you think is more important for a child to have: being considerate or well behaved?
a. Being considerate
b. Well behaved
c. Both
d. Neither
e. Don't know

Now I would like to ask you some questions regarding your views on groups in the United States. Each of the following questions will be answered on a scale from one to seven. Please circle the number that comes closest to your own view.

22. How hardworking do you think whites are? Rated on a scale of 1-7, 1 means you think almost all whites are "hardworking," 7 means that you think almost all whites are "lazy." A score of 4 means that you think whites are not toward one end or the other, and of course, you may choose any number in between that comes closest to where you think whites stand.

Please circle one: $\begin{array}{lllllll}1 & 2 & 3 & 4 & 5 & 6 & 7\end{array}$

23. How hardworking do you think blacks are? Rated on a scale of 1-7, 1 means you think almost all blacks are "hardworking," 7 means that you think almost all blacks are "lazy." A score of 4 means that you think blacks are not toward one end or the other, and of course, you may choose any number in between that comes closest to where you think blacks stand.

Please circle one: $\begin{array}{lllllll}1 & 2 & 3 & 4 & 5 & 6 & 7\end{array}$

24. How hardworking do you think Hispanics are? Rated on a scale of 1-7, 1 means you think almost all Hispanics are "hardworking," 7 means that you think almost all Hispanics are "lazy." A score of 4 means that you think Hispanics are not toward one end or the other, and of course, you may choose any number in between that comes closest to where you think Hispanics stand.

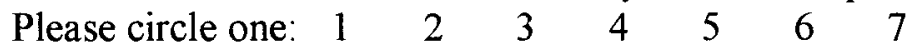


25. How hardworking do you think Asians are? Rated on a scale of 1-7, 1 means you think almost all Asians are "hardworking," 7 means that you think almost all Asians are "lazy." A score of 4 means that you think Asians are not toward one end or the other, and of course, you may choose any number in between that comes closest to where you think Asians stand.

Please circle one: $1 \begin{array}{lllllll}1 & 2 & 3 & 4 & 5 & 6 & 7\end{array}$

26. How intelligent do you think whites are? Rated on a scale of 1-7, 1 means you think almost all whites are "intelligent," 7 means that you think almost all whites are "unintelligent." A score of 4 means that you think whites are not toward one end or the other, and of course, you may choose any number in between that comes closest to where you think whites stand.

Please circle one: $\begin{array}{llllllll}1 & 2 & 3 & 4 & 5 & 6 & 7\end{array}$

27. How intelligent do you think blacks are? Rated on a scale of 1-7, 1 means you think almost all blacks are "intelligent," 7 means that you think almost all blacks are "unintelligent." A score of 4 means that you think blacks are not toward one end or the other, and of course, you may choose any number in between that comes closest to where you think blacks stand.

Please circle one: $\begin{array}{lllllll}1 & 2 & 3 & 4 & 5 & 6 & 7\end{array}$

28. How intelligent do you think Hispanics are? Rated on a scale of 1-7, 1 means you think almost all Hispanics are "intelligent," 7 means that you think almost all Hispanics are "unintelligent." A score of 4 means that you think Hispanics are not toward one end or the other, and of course, you may choose any number in between that comes closest to where you think Hispanics stand.

Please circle one: $\begin{array}{lllllll}1 & 2 & 3 & 4 & 5 & 6 & 7\end{array}$

29. How intelligent do you think Asians are? Rated on a scale of 1-7, 1 means you think almost all Asians are "intelligent," 7 means that you think almost all Asians are "unintelligent." A score of 4 means that you think Asians are not toward one end or the other, and of course, you may choose any number in between that comes closest to where you think Asians stand.

$\begin{array}{llllllll}\text { Please circle one: } & 1 & 2 & 3 & 4 & 5 & 6 & 7\end{array}$

30. How trustworthy do you think whites are? Rated on a scale of 1-7, 1 means you think almost all whites are "trustworthy," 7 means that you think almost all whites are "untrustworthy." A score of 4 means that you think whites are not toward one end or the other, and of course, you may choose any number in between that comes closest to where you think whites stand.

Please circle one: $\begin{array}{lllllll}1 & 2 & 3 & 4 & 5 & 6 & 7\end{array}$ 
31. How trustworthy do you think blacks are? Rated on a scale of 1-7, 1 means you think almost all blacks are "trustworthy," 7 means that you think almost all blacks are "untrustworthy." A score of 4 means that you think blacks are not toward one end or the other, and of course, you may choose any number in between that comes closest to where you think blacks stand.

Please circle one: $\begin{array}{llllllll}1 & 2 & 3 & 4 & 5 & 6 & 7\end{array}$

32. How trustworthy do you think Hispanics are? Rated on a scale of 1-7, 1 means you think almost all Hispanics are "trustworthy," 7 means that you think almost all Hispanics are "untrustworthy." A score of 4 means that you think Hispanics are not toward one end or the other, and of course, you may choose any number in between that comes closest to where you think Hispanics stand.

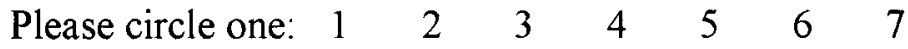

33. How trustworthy do you think Asians are? Rated on a scale of 1-7, 1 means you think almost all Asians are "trustworthy," 7 means that you think almost all Asians are "untrustworthy." A score of 4 means that you think Asians are not toward one end or the other, and of course, you may choose any number in between that comes closest to where you think Asians stand.

$\begin{array}{llllllll}\text { Please circle one: } & 1 & 2 & 3 & 4 & 5 & 6 & 7\end{array}$

\section{Please provide some information about yourself}

34. Sex:

Female

Male

35. What is your age? years

36. What is your college class?

$\begin{array}{ll}\square & \text { Freshman } \\ \square & \text { Sophomore } \\ \square & \text { Junior } \\ \square & \text { Senior } \\ \square & \text { Graduate student } \\ \square & \text { Doctoral student }\end{array}$

37. Which racial or ethnic group best describes you?

White

Black

Hispanic

Asian

Native American

Mixed 
38. Would you say you grew up in a home that was well off financially, somewhere in the middle, or poor?

- Well off

$\square$ Somewhere in the middle

$\square$ Poor

39. What is your religious affiliation?

- Traditional Protestant (Methodist, Episcopalian, Congregational, Lutheran, Presbyterian, 7th Day Adventist, Baptist, and the like)

Evangelical Christian or Fundamentalist

$\square$ Catholic (including Greek Orthodox)

$\square$ Jewish

$\square$ Islamic

$\square \quad$ No affiliation (including atheist)

$\square$ Other

40. Do you attend religious services EVERY WEEK, ALMOST EVERY WEEK, ONCE OR TWICE A MONTH, A FEW TIMES A YEAR, or NEVER?

$\square$ Every week

$\square$ Almost every week

$\square$ Once or twice a month

$\square$ A few times a year

$\square$ Never

41. Would you say religion provides a GREAT DEAL of guidance in your day-to-day life, QUITE A BIT of guidance, SOME guidance, or NO guidance at all?

A great deal of guidance

- Quite a bit of guidance

- Some guidance

$\square$ No guidance 


\section{CURRICULUM VITAE}

Christopher W. Ledford

3232 Aspen Valley Circle, Louisville, KY 40241

cwledf01@louisville.edu

\section{Education}

- Doctor of Philosophy in Political Science (American Political Behavior), University of Kentucky (beginning in Aug. 2012)

- Awarded five-year teaching assistantship

- Master of Arts in Political Science, University of Louisville (Aug. 2010forthcoming in May 2012)

- $3.8+$ GPA at 2012 Commencement

- Focused degree in American politics and behavior

- Took two Dept. of Political Science methods/statistics courses (4.0)

- Took two supplemental Dept. of Sociology doctoral program multivariate statistics courses (4.0)

- Conducted independent study focusing on legislative behavior

- Based on independent voting bill that entered Kentucky State Senate in 2010 Full Spring Session

- Worked as a Graduate Assistant in the 2011-2012 academic year

- Reviewed and edited manuscript for publication of The Political Economy of Necessity and the Biolimnological Vulnerability of Lake Victoria: A Thermodynamic Perspective, by: Dr. Okbazghi Yohannes

- Worked as a research assistant for Professor Michael Fowler, collecting information on mutual legal assistance treaties between the United States and Central American countries.

- POLS 202 - Comparative Political Systems (Dr. Tricia Gray)

- Graded quizzes and exams

- Posted campus and course announcements to course BlackBoard page.

- POLS 350 - African Politics (Dr. Okbazghi Yohannes)

- Drafted and graded weekly critical essay assignments for undergraduate students

- Proctored and graded final exams

- POLS 370 - Political Development in Latin America (Dr. Tricia Gray)

- Graded quizzes and exams

- Posted campus and course announcements to course page.

- Worked as a research assistant, collecting electoral data in Latin American countries for Dr. Gray's research in gender quotas. 
- POLS 390 - The Logic of Political Research (Dr. Jason Gainous)

- Instructed laboratory sessions on SPSS software and data analysis

- Instructed lecture sessions on political research and methodology

- Organized and led study sessions for exams

- Graded all homework and exams

- Assisted other professors in instructing courses and showing videos

- Senior undergraduate paper in Urban Issues revised and edited for publication in February 2012 for Goldstein Report

- Focused on the local application of business improvement districts in metropolitan Louisville

- Master's Thesis Experiment (pending defense in April 2012)

- "Ethnocentric Frames across Race: The Media's Role in Activating Ethnocentrism and Public Support for Conflict Abroad"

- Bachelor of Science in Political Science, Univ. of Louisville (Aug. 2006-Dec. 2009)

- Metropolitan College (UPS) 3.5 GPA Award

- Spring, Summer, Fall 2008

- University Dean's List, Fall 2008

- 3.41 Department of Political Science GPA

- Calculus I Summer Course, Somerset Community College (Summer 2006)

- Taken as a refresher to AP Calculus before first fall term at Univ. of Louisville

- Earned an A

- College Preparatory Diploma, Somerset High School, Somerset, KY (2002-2006)

- 3.2 Overall GPA

- 4.5+ Weighted GPA

- 7 AP Courses taken

- FCA, Teens Who Care

- Varsity Football -3 years

\section{Work Experience}

- United Parcel Service, Next Day Air Frontline Supervisor (July 2010-December 2011)

- Completed corporate management training school (Aug. 2010)

- Direct supervisor for 17 third-shift trailer and aircraft unload employees; oversight of approx. 20,000 UPS customers' packages per night.

- Responsible for providing nightly sort information, instruction, and quality safety and methods training to all employees

- Supervisor of one of the highest production unload areas at UPS' all-points Worldport operation

- Frankfort Legislative Internship, Kentucky State Senate (Jan. 2010-Apr. 2010)

- Organized meetings and appearances for Senator Jimmy Higdon

- Responded to constituent, voter, and interest group e-mails and telephone calls 
- Drafted legislation proposals and information packets for presentation by Senator Higdon in Senate Sessions

- Neil Huffman Honda, Lot Attendant, Clarksville, IN (Apr. 2010-July 2010)

o Picked up and delivered customer vehicles, parts, and new arrivals

$\circ$ Picked up and delivered customers

- Managed organization and arrangement of lot, garage, and stock areas

- Cleaned and detailed newly arrived and customer vehicles

- United Parcel Service, Next Day Air Unload (Aug. 2006-July 2010)

$\circ$ Unloaded trailers and aircraft containers

- Yard certified traffic director for aircraft container vehicles

- Shifting aircraft containers onto dock and into building

- Responsible for starting up all machinery and setting up area prior to shift

- Responsible for post-sort walk off, shutdown, and area cleanup

- Received three Employee of the Month awards

- Numerous monthly perfect attendance awards

\section{Volunteer Experience}

- I volunteered over 100 hours annually to a nonprofit music festival held in Somerset, KY from 2002-2008, and currently for the Jubilo Music and Arts Festival, performing numerous duties, such as: transporting profits to secure locations, transporting auctioned works of art, transporting artist merchandise, processing ticket orders, distributing marketing brochure and flyers statewide, and transporting artists and/or instruments from the airport/hotel/on site.

- Logged volunteer hours and monthly monetary donations to Visually Impaired Preschool Services, an organization I came to care for and support through United Parcel Service and partner Metro United Way.

\section{References}

- Senator Jimmy Higdon ( R - Lebanon)

507 West Main Street

Lebanon, KY 40033

Office: (502) 264-8100

- Steven Marinakis, FT Supervisor, United Parcel Service, Worldport North Core

Unload

911 Grade Lane - North Core Unload

Louisville, KY 40213

Office: (502) 247-3012

- Dr. Jason Gainous

American Politics, Political Behavior, Research Methods

University of Louisville

Ford Hall Room 406

Louisville, KY 40292

Office: (502) 852-1660 
- Dr. Laurie Rhodebeck

American Politics, Parties and Elections, Media and Politics, Research Methods

University of Louisville

Ford Hall Room 405

Louisville, KY 40292

Office: (502) 852-3313

- Dr. David Imbroscio

Political Economy, Public Policy, Urban Politics

University of Louisville

Ford Hall Room 107

Louisville, KY 40292

Office: (502) 852-3311 